\title{
圆
}

CONSELHO NACIONAL DE DESENVOLVIMENTO CIENTIFICO E TECNOLOGICO (CNPq) INSTITUTO NACIONAL DE PESQUISAS DA AMAZÔNIA (INPA)

\section{The myology of the Amazonian Manatee, Trichechus inunguis (Natterer) (Mammalia: Sirenia)}

\author{
Daryl P. Domning \\ INPA - Manaus
}


DOMNING, Daryl P.

The myology of the Amazonian Manatee, Trichechus inunguis

(Natterer) (Mammalia: Sirenia) Acta Amazonica, Manaus, 8(2) :

Suplemento (1) jun., 1978.

81 p. ilus.

1. Sirenia 2. Manatee 3. Peixe-boi 4. Anatomia do Peixe-

boi 5. Mamíferos 6. Zoografia 1. Título.
CDD 599.5
591.4
CDU 599.55(8.811.3)
591.9
591.4
$591.9(26)$

ABSTRACT: The muscles of the Amazonian manalee are described and compared with those of other manatees and the dugong. Maps of muscle attachments and data on weights of muscles are included. The manatee species differ in the forms of the $\mathrm{mm}$. rectus capitis lateralis and biceps brachii. The mechanisms of protrusion of upper-lip bristles and opening of the nostrils are described. The jaw apparatus is uniquely specialized, with a very large temporalis muscle constituting more than half the adductor muscle mass, and development of a joint between the pterygoid process and the mandible which prabably braces the mandible during transverse chewing. The center of mandibular rotation in transverse chewing probably lies posteromedial to the pterygoid process on the active side: the contralateral temporalis is dominant in transverse chewing. Trichechus inunguis is more specialized for surface-feeding and for swimming than T. manatus.

RESUMO: Os músculos do peixe-boi da Amazônia são descritos e comparados àqueles dos outros peixes-bois e do dugong. Mapas das ligações dos músculos aos ossos, e dados sobre pesos dos músculos, são incluídos. Notam-se diferenças entre as espécies de peixes-bois com respeito aos músculos rectus capitis lateralis e biceps brachii. Descrevem-se $\circ$ mecanismo de protrusão das cerdas do lábio superior, e o mecanismo de abertura das narinas. O aparelho masticatório é unicamente especializado, com um temporalis muito grande, constituindo mais que metade do peso dos músculos adutores, e com uma articulação entre o processo pterigoídeo e a mandíbula. Esta provavelmente apoia a mandíbula na mastıgação transversal. $O$ centro de rotação da mandibula na mastigação transversal parece ficar posteromedial ao processo pterigoídeo no lado ativo; o temporalis do outro lado fornece a maioria da força para esta rotação. a Trichechus inunguis é mais especializado do que o $\mathbf{T}$. manatus para se alimentar perto da superfície da água, e para nadar. 
Introduction $\ldots \ldots \ldots \ldots \ldots \ldots \ldots \ldots \ldots \ldots \ldots, \quad 5$

Acknowledgments $\ldots \ldots \ldots \ldots \ldots \ldots \ldots \ldots \ldots \ldots, 5$

Material, Methods, and Terminology $\ldots \ldots \ldots \ldots \ldots \ldots \ldots \quad 6$

Myological Descriptions ....................... 8

Muscles of the Superficial Neck and Face Region .... 8

Muscles of the Jaws ........................ 16

Muscles of the Middle Ear .................... 17

Extrinsic Muscles of the Eyeball ............... 17

Tongue and Hyoid Muscles .................... 18

Muscles of the Pharynx .................... 22

Muscles of the Soft Palate ................... 22

Muscles of the Larynx ..................... 24

Dorsal Muscles of the Trunk .................. 25

Epaxial Spinal Musculature ..................... 25

Transversospinalis System ................. 25

Longissimus System $\ldots \ldots \ldots \ldots \ldots \ldots \ldots \ldots, 27$

Iliocostalis System .................... 27

Deeper Muscles of the Neck ................ 28

Muscles of the Thorax ..................... 31

Muscles of the Abdomen ..................... 34

Muscles of the Tail ........................ 35

Muscles of the Shoulder .................... 36

Muscles of the Forelimb ................... 39

Muscles of the Pelvic and Genital Region (Female) .. 48

Muscles of the Pelvic and Genital Region (Male) .... 52

Interspecific Differences $\ldots \ldots \ldots \ldots \ldots \ldots \ldots \ldots \ldots .54$

Myology of Dugong: Corrigenda $\ldots \ldots \ldots \ldots \ldots \ldots \ldots, \quad 56$

Functional Anatomy $\ldots \ldots \ldots \ldots \ldots \ldots \ldots \ldots \ldots \ldots, \quad 57$

Bristles of the Upper Lip .................. 57

Opening of the Nostrils $\ldots \ldots \ldots \ldots \ldots \ldots \ldots \ldots, \quad 57$

Jaw Muscles ............................. 57

Neck Muscles ........................... 67

Forelimb Muscles $\ldots \ldots \ldots \ldots \ldots \ldots \ldots \ldots \ldots \ldots . \ldots 6$

Resumo $\ldots \ldots \ldots \ldots \ldots \ldots \ldots \ldots \ldots \ldots \ldots \ldots, \quad 72$

Literature Cited $\ldots \ldots \ldots \ldots \ldots \ldots \ldots \ldots \ldots \ldots \ldots, \quad 73$

List of Abbreviations $\ldots \ldots \ldots \ldots \ldots \ldots \ldots \ldots \ldots, \quad 75$

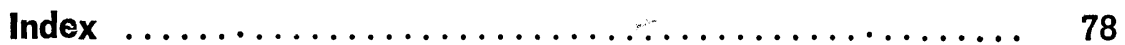




\section{The myology of the Amazonian manatee, Trichechus inunguis (Natterer) (Mammalia: Sirenia) \\ Daryl P. DOMNING *}

RESUMO

Os músculos esqueléticos do peixe-boi da Amazônia (Trichechus inunguis) são descritos, ilustrados e comparados com prévias descrições dos sistemas musculares dos peixes-bois e do dugong. Mapas das ligaçōes dos músculos aos ossos, e dados sobre os pesos dos músculos da queixada, da nadadeira etc. são incluidos. Notam-se diferenças entre as espécies de peixes-bois com respeito aos músculos rectus capitis lateralis e biceps brachii, e também entre os peixes-bois e o dugong. Corrigem-se algumas interpretações errôneas na descriçăo (Domning, 1977) da miologia do Dugong. Descrevem-se o mecanismo de protrução das cerdas do lábio superior, e o mecanismo de abertura das narinas: estas säo fechadas involuntariamente por tecido elástico. Análise com vetores dos músculos da queixada do Trichechus inunguis indica que os sirênios năo podem ser colocados em nenhuma das categorias adaptivas demarcadas por Turnbull (1970). Ao contrário, eles constituem um grupo divergentamente especializado, que se caracteriza, em parte, por possuir um mủsculo temporalis muito grande e vantajosamente situado, constituindo mais que metade do peso dos músculos adutores, e por uma articulação entre o processo pterigoideo e a mandibula. Esta articulaçăo serve, provavelmente, para apoiar a mandíbula na mastigaçāo transversal. O centro de rotaçăo da mandíbula na mastigação transversal parece ficar posteromedial ao processo pterigoídeo no lado ativo; o temporalis do outro lado fornece a maioria da força necessária para esta rotação. Particularidades dos músculos e articulaçōes do pes. coço favorecem a hipótese que o $T$. Inunguis é mais especializado do que o $T$. manatus para se alimentar perto da superfície da água. A nadadeira do $T$. inunguis é mais especializada para nadar do que a do $T$. manatus, mas não apresenta o grau de adaptaçăo encontrado no Dugong, para movimentos parasagitais do ombro. 
In an earlier work (Domning, 1977a) on the muscular system of the dugong, I reviewed in passing the somewhat scanty literature on myology of the manatees. This is still an inadequately known topic. As can be seen from the summary in Table 1, such descriptions as exist are for the most part fragmentary.
Based on material of widely varying quality and done by different anatomists usually only peripherally interested in myology, they afford no adequate basis for interspecific comparisons or functional analysis. The present study of Trichechus inunguis is an effort to partly remedy this lack of information.

TABLE 1. Previous descriptions of the myology of Trichechus.

\begin{tabular}{|c|c|c|}
\hline Portions Described & Reference & Remarks \\
\hline T. manatus Linnaeus, 1758 & & $1-$ \\
\hline Male pelvic muscles & Vrolik, 1852 & Based on 1 immature specimen \\
\hline Male and female pelvic muscles & Krauss, 1872 & Based on 3 males and 3 females \\
\hline Entire body & Murie, 1872,1880 & Based on 2 immature specimens and 1 adult \\
\hline Brief allusions to eye muscles & Puittcr, 1902 & Based on 1 embryo \\
\hline Intrinsic tongue muscles & Gudernatsch, 1909 & Based on 1 specimen \\
\hline Brief allusion to eye muscles & $\begin{array}{l}\text { Quiring and } \\
\text { Harlan, } 1953\end{array}$ & Based on 1 adult female \\
\hline \multicolumn{3}{|l|}{ T. senegalensis Link, 1795} \\
\hline Male pelvic muscles & Petit, 1925 & Based on 1 immature specimen \\
\hline Forelimb muscles & Bahrdt, 1933 & Based on 1 juvenile \\
\hline Facial muscles & Saban, 1975 & Based on 1 immature specimen \\
\hline \multicolumn{3}{|l|}{ T. inunguis (Natterer, 1883) } \\
\hline Several parts of body & Stannius, 1845,1849 & Based on 1 juvenile male \\
\hline Female pelvic muscles & Freund, 1930 & $\begin{array}{l}\text { Based on } 1 \text { adult female, said to be one of the } \\
\text { "Manatus latirostris" described by Vosseler } \\
\text { (1924-25); but the latter were T. inunguis! }\end{array}$ \\
\hline Male pelvic muscles & Kaudern, 1917 & Based on 1 fetus \\
\hline Back muscles & Slijper, 1946 & $\begin{array}{l}\text { Based on } 1 \text { adult male said to be } \mathbf{T} \text {. inunguis, } \\
\text { but as it had } 18 \text { thoracic vertebrae it was } \\
\text { more likely one of the other species. }\end{array}$ \\
\hline
\end{tabular}

\section{ACKNOWLEDGMENTS}

This work was done at the Instituto $\mathrm{Na}$ cional de Pesquisas da Amazônia (INPA), Manaus, Brazil, as part of an ongoing research program on the biology of the Amazonian manatee. This program is supported by the Conselho Nacional de Desenvolvimento Científico e Tecnológico (CNPq) of Brazil, and by grants from the Vancouver Public Aquarium,
British Columbia, Canada, and the Fauna Preservation Society of Great Britain. I thank Robin Best, Diana Magor, and Anthony Rylands for assistance and collection of specimens, Drs. Roger Saban and William D. Turnbull for criticism of the manuscript, and Dr. Warwick Kerr, Director of INPA, and Dr. Wolfgang Junk, head of the Divisão Peixe/Pesca of INPA, for their unfailing support and encouragement. 


\section{MATERIALS, METHODS, AND TERMINOLOGY}

The specimens used in this study are described in Table 2. The muscle descriptions and illustrations are principally based on INPAPB 14, the embalmed carcass of a young female calf, which was the most thoroughly dissected. Observations on most regions of the body were made in the course of fleshing out the skeletons of INPA-PB 6,8 , and 9; dissections of INPA-PB 12, 108, 117, and 169 provided supplementary information. Specimens other than INPA-PB 14 are mentioned in the text only where they were found to differ from it; unless otherwise stated, all descriptive statements refer to INPA-PB 14.

As the forms and relations of most muscles are similar in all sirenians and have been described at some length in the works alluded to above, I give here somewhat abbreviated accounts of them, emphasizing origins, insertions, and interspecific and intras- pecific variations. Literature citations refer, where not otherwise stated, only to descriptions of Trichechus; for references to the myology of Dugong, see Domning, 1977a.

Muscle homologies suggested are based on gross relations. In the headings of individual muscle descriptions, muscle names in quotation marks are names I have coined. The illustrations are semidiagrammatic and, with a few exceptions, structures other than muscles, tendons, and bones are omitted. The directions of muscle fibers are indicated by solid lines, and those of tendinous or aponeurotic fibers by dashed lines. Muscle origins are denoted by a pattern of circles, insertions by a pattern of vertical dashes. The abbreviations beginning with capital letters refer to muscles and those beginning with lower-case letters refer to other structures; all are explained in the "List of Abbreviations" or in the captions.

TABLE 2. Material of Trichechus inunguis used in present study.

\begin{tabular}{|c|c|c|c|c|c|c|c|c|}
\hline $\begin{array}{c}\text { Specim } \\
\text { Sex, }\end{array}$ & $\begin{array}{l}\text { men } \mathrm{n} \\
\text { and }\end{array}$ & & $\begin{array}{l}\text { iber, } \\
\text { ge }\end{array}$ & $\begin{array}{l}\text { Body Length } \\
\text { (curved line) } \\
\text { (cm) }\end{array}$ & $\begin{array}{l}\text { Maximum } \\
\text { Girth } \\
(\mathrm{cm})\end{array}$ & $\begin{array}{l}\text { Weight } \\
\text { (kg) }\end{array}$ & Locolity & Parts Dissected \\
\hline & i & & & & & & & \\
\hline INPA-PB. & & 우 & (juv.) & 100.2 & 61.6 & 14 & Central Amazon Basin & Entire body \\
\hline INPA-PB & 8 & & (juv.) & 97.2 & 67.9 & 15 & Central Amazon Basin & Entire body \\
\hline INPA-PB & 9 & $\hat{o}$ & (juv.) & 92.5 & 53.8 & 10.5 & $\begin{array}{l}\text { Near Manacapuru, Rio } \\
\text { Solimões, Amazonas }\end{array}$ & Entire body \\
\hline INPA-PB & 12 & 운다 & (juv.) & 103.5 . & 61.0 & 14 & $\begin{array}{l}\text { Paraná Autáz-Açú, lower } \\
\text { Rio Madeira, Amazonas }\end{array}$ & Facial muscles \\
\hline INPA-PB & 14 & 우 & (juv.) & 107.1 & 70.2 & 18 & $\begin{array}{l}\text { Lago do Acará Grande, } \\
\text { Paraná Autáz-Açú, lower } \\
\text { Rio Madeira, Amazonas }\end{array}$ & Entire body \\
\hline INPA-PB & 108 & s & (adult) & $205^{\star}$ & $?$ & $\sim 160$ & $\begin{array}{l}\text { Ilha Juçara, near Coari, Rio } \\
\text { Solimôes, Amazonas }\end{array}$ & Male pelvic muscles \\
\hline INPA-PB & 117 & * & (adult) & $222^{*}$ & $?$ & $\sim 250$ & $\begin{array}{l}\text { Lago Mamori, south } \\
\text { of Manaus, Amazonas }\end{array}$ & $\begin{array}{l}\text { Larynx and right } \\
\text { forelimb }\end{array}$ \\
\hline INPA-PB & 169 & & (juv.) & ? & $?$ & ? & Central Amazon Basin & Head \\
\hline
\end{tabular}

* Straight-line lengths. 
The specimens used in this study all had 6 cervical, 15 thoracic, and 25 or 26 postthoracic vertebrae, and 15 pairs of ribs, of which 3 attached to thte sternum, except in INPA-PB 6 where only two were attached. (In INPA-PB 8 , the third costal cartilage ended about halfway to the sternum and was connected to it only by a ligament.) As there is no welldefined ligament connecting the ischium with, and thereby serving to identify, a sacral vertebra, I have avoided trying to distinguish between lumbar, sacral, and caudal vertebrae. There are 8 pairs of chevron bones, the anteromost pair articulating with postthoracic vertebrae 3 and 4 .

Muscle wet weightts (Tables 3,8 ) were determined by careful excision and weighing in a cool, humid environment; weight loss due to desiccation is believed to have been negligible. All specimens had previously been frozen. As all jaw muscle weights were taken from calves too young to have been weaned and which had probably not begun to eat a significant quantity of solid food, it is uncertain whether they show exactly the conditions found in adults, though it is improbable that the adult muscle proportions are significantly different.

All specimens discussed are deposited and cataloged in the collection of the Instituto Nacional de Pesquisas da Amazônia, Departamento Peixe-Boi (INPA-PB), Manaus, Brazil. 
MYOLOGICAL DESCRIPTIONS

\section{MUSCLES OF THE SUPERFICIAL NECK AND FACE REGION}

\section{SPHINCTER COLLI SUPERFICIALIS (SpC:}

Figs. 2-4, 6) :

(Murie, 1972: 164, figs. 8, 9, 13, 30: "platysma myoides, P. c ${ }^{3}$; Saban, 1975: 233, 234, 236-238, 241-243, figs. 1, 3, 4: "sphincter colli superficialis" + "sphincter colli profundus pars intermedia ventralis" + "sphincter colli profundus pars palpebralis".)

ORIGIN: Anteriorly, from midventral line (continuous with fellow); from level of shoulder to about level of axilla, fibers begin progressively more laterally.

INSERTION: Forms very thin and inconspicuous sheet of fibers covering lower half of face and front of shoulder, and adhering to underlying platysma. Continued dorsally by aponeurosis which attaches to lower edge of orbit and passes dorsad forward and aft of eye.

REMARKS: $\mathrm{S} a \mathrm{~b}$ an distinguished three portions of this superficial sheet in $T$. senegalensis, though as they all overlie the platysma, it is not clear to me why he considered two of them parts of the sphincter colli profundus. I did not observe an extension (Murie's "P. $C^{3 * ")}$ along the flipper to the base of metacarpal I.

\section{PLATYSMA :}

Two of the divisions of this sheet which I recognized in Dugong (Domning, 1977a), the partes temporalis and scapularis, are absent in $T$. inunguis, nor were auricular muscles observed. As in other manatees, the platysma pars jugularis is here continuous with the cutaneus trunci..
"M. PLATYSMA PARS JUGULARIS" (PIJ : Figs. $1,2,4,5,11$ ):

(Murie, 1872: 163, figs. 8, 9, 10: "panniculus carnosus, P.c'" of text, in part; Saban, 1975: 233-236, 241-244, figs. 1-4: "platysma myoides", including "pars auricularis", "pars zygomatica", and "pars buccalis" or "zygomatico-labialis".)

ORIGIN : From muscular and connective tissue on sides of snout and from circumoral muscles; and by aponeurosis from lower edge of orbit (Saban's "pars zygomatica") and covering surface of zygomatic arch. Some fibers arise just behind auditory meatus (Saban's "pars auricularis"), while bulk of muscle passes just ventral to meatus. In one specimen, however (INPA-PB 12), conditions more resembled those in Saban's $T$. senegalensis; aponeurosis arose from entire posterior edge of orbit, and entire muscle passed ventral to meatus, with only a tiny bundle of fibers passing posteroventrad from meatus.

INSERTION: Passes aft across dorsal part of scapula to become continuous with cutaneus trunci $(q \cdot v \cdot)$.

REMARKS: The labelling of various parts of the cutaneus muscles in Murie's figures is inconsistent, but their arrangement seems to be similar to that described here. Saban regards the anteromost portion of this muscle as a "zygomatico-labialis" because it lies deep to what he considers the "sphincter colli profundus pars palpebralis" (p. 236); I find it simpler to avoid the difficulty by grouping the latter fibers with the sphincter colli superficialis, as noted above.

M. SPHINCTER COLLI PROFUNDUS :

- ? PARS AURIS (Au: Figs. $3,5,6,11,26$ ) :

(Murie, 1872: 163-164, figs, 8, 9: "panniculus carnosus, P.c ${ }^{2}$, in part; Murie, 1880: pl. 8: fig. 5.) 

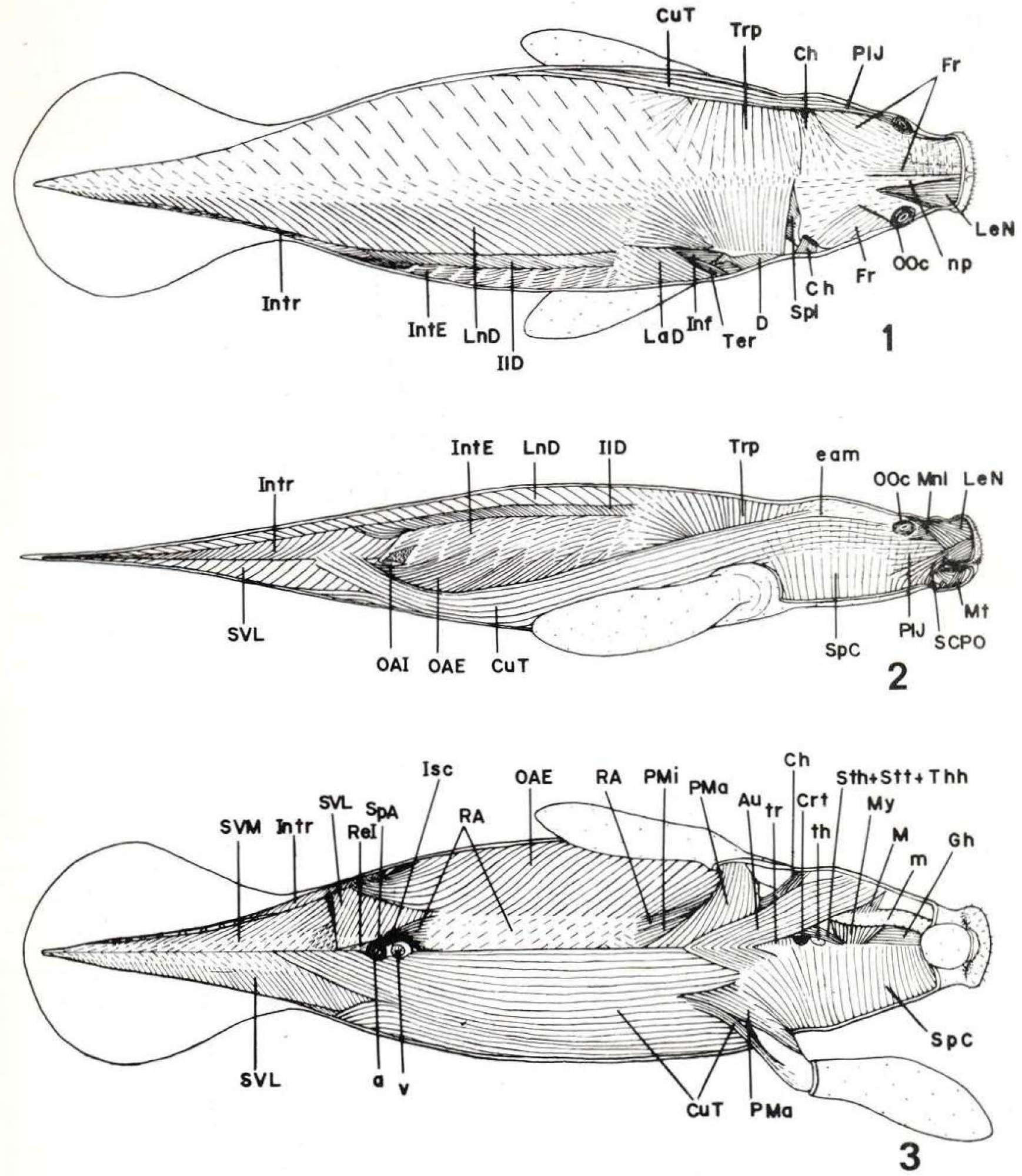

Figs: $1-3$ - Dorsal, lateral, and ventral views of young female calf: 1, superficial muscles and aponeuroses on left side, second layer shown on right; 2, with superficial aponeuroses only removed; 3 , superficial muscles shown on left side, sphincter colli superficialis, cutaneus trunci, and most of sacrococcygeus ventralis lateralis removed from right side. 
ORIGIN: Tendinous, with fellow of opposite side, from exact midline of manubrium between origins of pectorales major, from just abaft origin of sternomastoideus to about level of attachments of costal cartilages.

INSERTION : By strong aponeurosis, containing distinct tendons from separate muscle bundles, onto line along side of zygomatic arch behind eye. Aponeurosis lies on deep side of muscle and is there divided into more or less distinct bands. In INPA-PB 169, fibers reached no more than about $2 \mathrm{~cm}$ anterodorsad of posterior edge of mandible; aponeurosis of insertion consisted only of an indistinct sheet of separate (though strong) tendinous bands buried in fat.

REMARKS: This agress with the conditions observed in Dugong (Domning, 1977a) and $T$. manatus. However, Saban (1975) failed to find such a muscle in $T$. senegalensis. Its absence in that species alone of the four-living sirenians would be extraordinary; more likely it was overlooked, as it can be quite inconspicuous near its insertion in juvenile specimens, as noted above, especially if fat deposits in this area are well developed.

\section{- PARS INTERMEDIA :}

- M. FRONTALIS (Fr: Figs. 1, 5, 10):

ORIGIN: Fleshy from dorsal surface of frontal, and by thin aponeurosis from lateral side of zygomatic process (superficial but adherent to aponeurosis of pars auris, and covered by aponeurosis of cephalohumeralis). Forms very thin sheet covering forehead and whole temporal fossa from sigmoid ridge (where it lies deep to cephalohumeralis) to orbit; here its fibers can be indistinctly seen passing anterodorsad. Posteriorly it covers large vascular rete passing dorsad across temporalis. In INPA-PB 12 it was largely aponeurotic, with fibers mostly confined to abaft the auditory meatus.

INSERTION: Fleshy and tendinous onto whole dorsal surface of narial passages.

REMARKS: May or may not be equivalent to the ?frontalis I observed in Dugong
(Domning, 1977a). The superciliaris noted by Saban (1975: 237, figs. 1, 2) in T. senegalensis, and not otherwise recorded in sirenians, had a fiber direction similar to that of the frontalis and may be related to it. Saban (1975: 243) suggested that the "pyramidalis nasi" of Murie (1872: 148, fig. 12) might have been a modified frontalis, but it seems to have been too thick and deep to correspond to the muscle described here.

- M. ORBICULARIS OCULI (OOc: Figs. 1, 2, 4-9, 24) .

(Murie, 1872: 195, fig. 8: “orbicularis palpebrarum"; Putter, 1902: 180; Saban, 1975: 237, 242,243 , figs. $1,3,4$.)

I could not discern any distinct discontinuity of fibers either anteriorly or posteriorly, though an anterior discontinuity has been observed in this muscle in both Dugong and $T$. senegalensis.

- M. LEVATOR NASOLABIALIS (LeN: Figs. 1, 2, 4, 5, 10, 24):

(Murie, 1872: 149, figs. 8, 10, 12: "levator labii superioris alkequae nasi"; Saban, 1975: 237-239, 241, 242, 244, figs. 1, 2: "naso-labialis".)

ORIGIN: Tendinous from anterior edge of orbit and from ridge crossing dorsal side of supraorbital process of frontal.

INSERTION: Passes anteroventral into lateral part of front of snout.

REMARKS: Murie stated, no doubt incorrectly, that the fibers arise "from the outer side of the nasal cartilage upon the superior maxillary bone" and are "partially inserted into the intermaxillary bones" in $T$. manatus.

\section{- PARS PALPEBRALIS :}

A palpebral muscle like that of Dugong (Domning, 1977a) has not been observed in manatees; the more superficial muscle of $T$. senegalensis identified as a palpebralis by Saban (1975: 234, 236-238, 241-243, figs. 1, 3, 4) I prefer to regard as part of the sphincter colli superficialis, as explained above. 


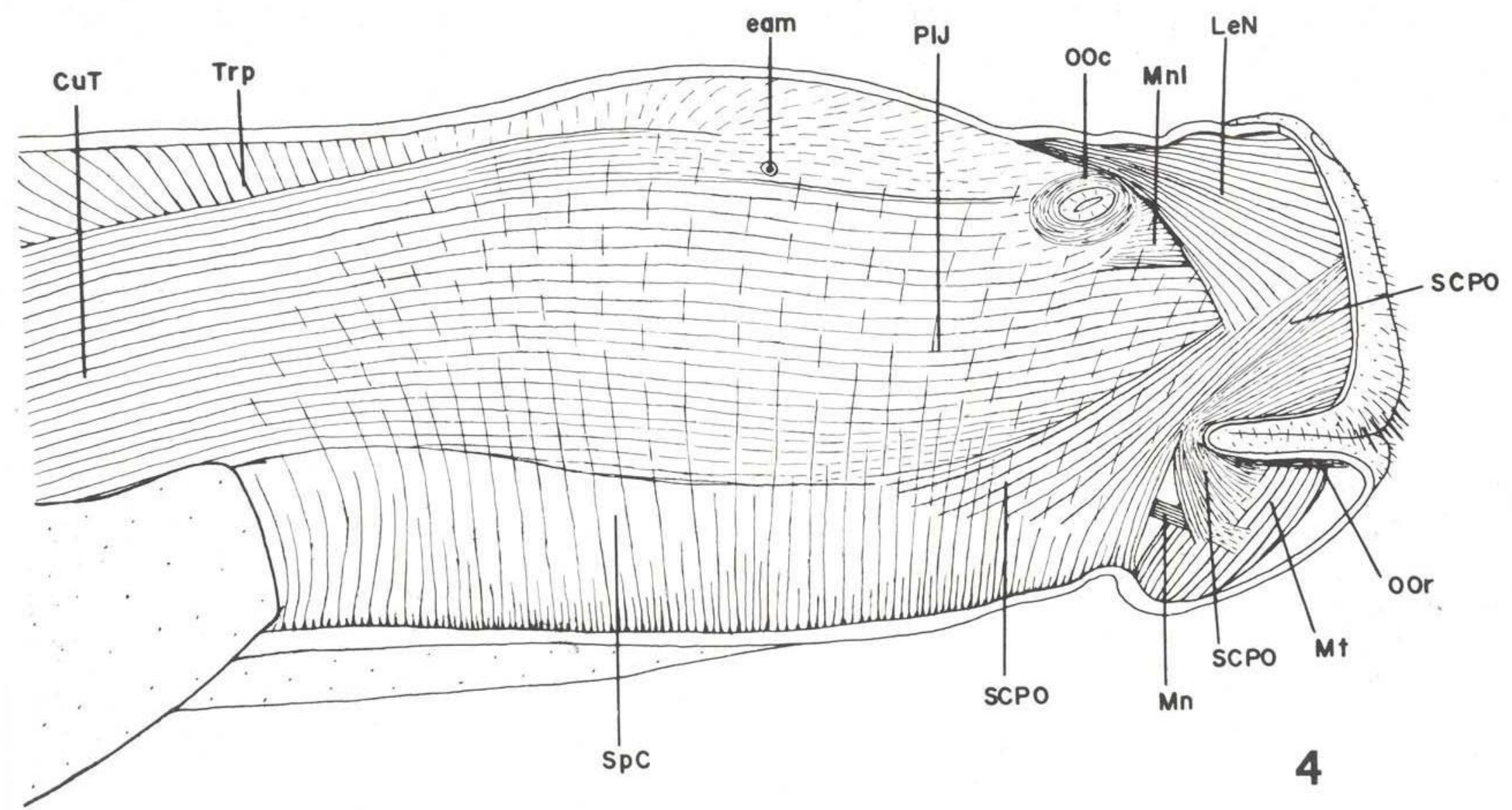

$\stackrel{1}{\rightrightarrows}$

Fig. 4 - Lateral view of head and neck; superficial muscles. 
- PARS ORIS (SCPO: Figs. 2, 4):

(Murie, 1872: 150, figs. 8, 9, 10, 12: "panniculus carnosus, P.c2", in part, + ? "depressor anguli oris"; Saban, 1975: 234, 237-239, 241-242, 244, figs. 1-4.)

Distinct sheet of fibers forming most superficial layer on ventral part of upper lip. Fibers pass posteroventrad from front of snout across levator nasolabialis to angle of mouth, the more posterodorsal ones decussating with and partly overlain by fibers of levator nasolabialis. Behind angle of mouth, some fibers turn anteroventrad across surface of mentalis to insert on hide just below angle of mouth, while more posterior ones continue ventrad to meet their fellows under mandible and behind chin; latter slinglike part is posteriorly more or less continuous with sphincter colli superficialis, whose fibers are parallel to it. Posteromost fibers of pars oris have more posteroventrad direction, becoming nearly parallel to subjacent fibers of platysma para jugularis.

REMARKS: Murie does not describe this in his text, though his figures show at least the posteroventral part clearly; the anteroventral part probably corresponds to his "depressor anguli oris" (1872: 150, figs. 8-10). T. senegalensis agrees well with $T$. inunguis. This muscle is, however, inseparable from the orbicularis oris in all sirenians, and doubtless corresponds in large part to the "orbicularis oris" I described in Dugong (Domning, 1977a). In addition to the above, the following separately named muscles are also derivatives of the sphincter colli profundus pars oris:

\section{- M. ORBICULARIS ORIS (OOr: Figs.} $4,5)$ :

(Murie, 1872: 150, figs. 10, 11; Saban, 1975: 239-242, figs. 3, 4, 6: "buccinator pars orbicularis oris".)

Fibers closely adherent to hide of edges of lips; otherwise inseparable from portion of pars oris described above.

- M. BUCCINATORIUS (Bu: Figs. 5, $6,11,12,14,15)$ :

(Murie, 1872: 150, figs. 10, 11; Saban, 1975: 239-244, fig. 4: "buccinator, partes maxillo-mandibularis et longitudinalis".)
Arise from lateral borders of maxilla and premaxilla from rear of tooth row to front of rostrum, where it blends with lateralis nasi; and from alveolar border of mandible from base of ascending ramus (dorsomedial to coronoid canal) to forward of tooth row, where it blends witth orbicularis oris. In its superficial layer, fibers are isolated and more or less vertical in anterior part of muscle; farther aft the superficial fibers are posteroventrally aligned and more closely spaced. Deep fibers are longitudinally (anteroventrally) aligned, and more separated by connective tissue from superficial layer anteriorly than posteriorly.

REMARKS: The superficial layer (pars buccalis or maxillo-mandibularis) was not nearly as distinct or separable from the deep (pars molaris or longitudinalis) as shown by Saban for $T$, senegalensis.

- M. MANDIBULARIS (Mn: Figs. 4, 5, 15, 26):

(Murie, 1872: 150-151, fig. 11; Saban, 1975: 239-242, 244, figs. 3, 4: "buccinator pars mentalis".)

ORIGIN: Tendinous and fleshy from medial edge of anteromedial side of base of ascending ramus of mandible, just above coronoid canal; related to buccinatorius on medial side.

INSERTION: Passes anteroventrad as prominent fusiform muscle with fine, closely packed fibers, to insert by strong tendon into hide on side of chin lateral to mentalis.

REMARKS: This is unquestionably identical to the "mandibularis" named by Murie in $T$. manatus, and evidently homologous with the "buccinator pars mentalis" of $T$. senegalensis; however, the latter takes origin not from the mandible but from the pterygoid process in common with the "buccinator pars longitudinalis" (Saban, in litt., 26 May 1976). While this may not be a significant difference in a muscle which is an apparent derivative of the buccinatorius in any case, it is worth noting that in Dugong (Domning, 1977a) there are two similar muscles present in this region: a mandibularis arising from the mandible like those of $T$. manatus and $T$. inunguis, and a 


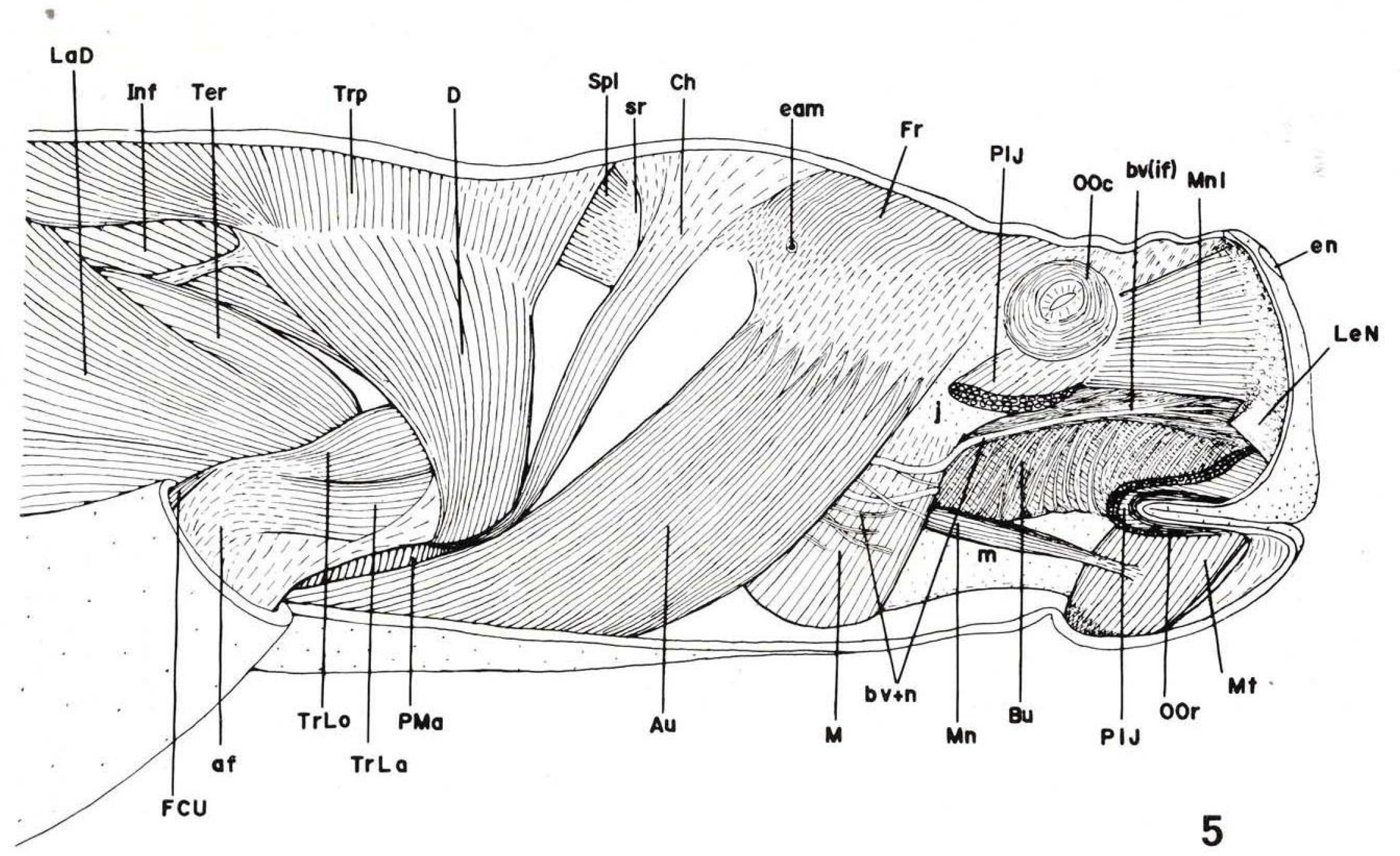

I Fig. 5 - Lateral view of head, neck and shoulder; second layer of muscles. Spaces anterior and posterior to cephalohumeralis are occupied by large $\vec{\omega} \quad$ vascular retia. Sphincter colli superficialis removed. 
"retractor labiorum" arising from the maxilla together with the buccinatorius. Most likely the latter is unique to Dugong and the "buccinator pars mentalis" of $T$. senegalensis is really homologous with the mandibulares of the other three forms despite its different site of origin.

The supposed "depressor anguli oris" of Dugong (Domning, 1977a), represented by fibers continuous with the tendon of the mandibularis, was not detected in $T$. inunguis; the "depressor anguli oris" of Murie is probably represented by part of the sphincter colli profundus pars oris sensu stricto (q.v.).

\section{- M. MAXILLONASOLABIALIS (Mnl:}

Figs. 2, 4, 5, 10-12, 24):

(Murie, 1872: 148-149, figs. 8, 10, 11, 12: "levator labil superioris proprius" + ? "dilatator naris"; Saban, 1975: 238, 242-244, figs. 1, 2, 4: "maxillo-labialis" + ? "dilatator nasi".)

ORIGIN: Tendinous from anteroventral border of orbit.

INSERTION: Passes slightly anterodorsad as broad sheet deep to levator nasolabialis, inserting fleshily into upper part of snout and onto side of narial passage.

REMARKS: I found this to be a single sheet; Saban's "dilatator nasi" in $T$. senegalensis seems to correspond to its dorsal part.

- M. LATERALIS NASI (LaN: Figs. 6 , $10,11,24)$ :

(Murie, 1872: 148, 149, figs. 11, figs. 11, 12: "levator anguli oris" + "depressor labii supe rioris alaeque nasi" + "pyramidalis nasi" + "compressor nasi"; Saban, 1975: 237, 242-244, figs. 1, 2, 4: "naso-labialis superficialis".)

ORIGIN: Fleshy from premaxilla on side of rostrum and inside mesorostral fossa. In INPAPB 169, a well-developed set of transverse fibers was observed arising (fleshily and tendinously) from dorsal extremity of maxilla lateral to premaxilla, and from line extending posteromediad beneath levator nasolabialis along posteriorly adjacent supraorbital process.
INSERTION: Fibers pass vertically onto hide, into connective tissue around apex of snout, and onto ventral and lateral sides of narial passage. Together with sphincter colli profundus pars oris, levator nasolabialis, and maxillonasolabialis it contributes to the largely undifferentiated mass of muscle and connective tissue forming front of snout which also includes transverse fibers crossing front of snout ventral to nares. Transverse fibers observed in INPA-PB 169 passed anteromediad onto side of narial passage and (posteriorly) nasal cartilage, and were continuous with lateralis nasi fibers arising from premaxilla. More anteriorly, small fibers were scattered in connective tissue over narial passages, but with no clear transverse orientation.

REMARKS: The nomenclature of the muscles of this region remains unsatisfactory. I could distinguish only a continuous mass of fibers, which I take to include the above-listed parts tentatively identified by Murie; the transverse fibers seen in INPA-PB 169, at least, clearly correspond to his "pyramidalis nasi".

Murie (1872: 148, figs. 11, 12) described a "zygomaticus" arising "from the deep infraorbital fossa" and "inserted into the anterior portion of the naris" with the lateralis nasi. This seems to correspond to Saban's (1975: 239, 241-244, fig. 4) "naso-labialis profundus" in $T$. senegalensis. I have not observed it in either $T$. inunguis or Dugong.

- - M. MENTALIS (Mt: Figs. 2, 4, 5, 14, 26) :

(Murie, 1872: 150, figs. 8, 9, 10, 11: "depressor labii inferioris"; Saban, 1975: 240-243, figs. 3, 4.)

ORIGIN: Fleshy from lateral side of mandibular symphysis, dorsal to mental foramina.

INSERTION: Fibers pass posteroventrad onto skin at lower corner of symphysis.

REMARKS: Murie seems to imply, incorrectly, that the muscle pulls down on the lower lip rather than up on the hide of the chin. Its attachments are shown correctly by Saban.

Murie's (1872: 149-150, fig. 9) "levator labii inferioris", composed of longitudinally- 


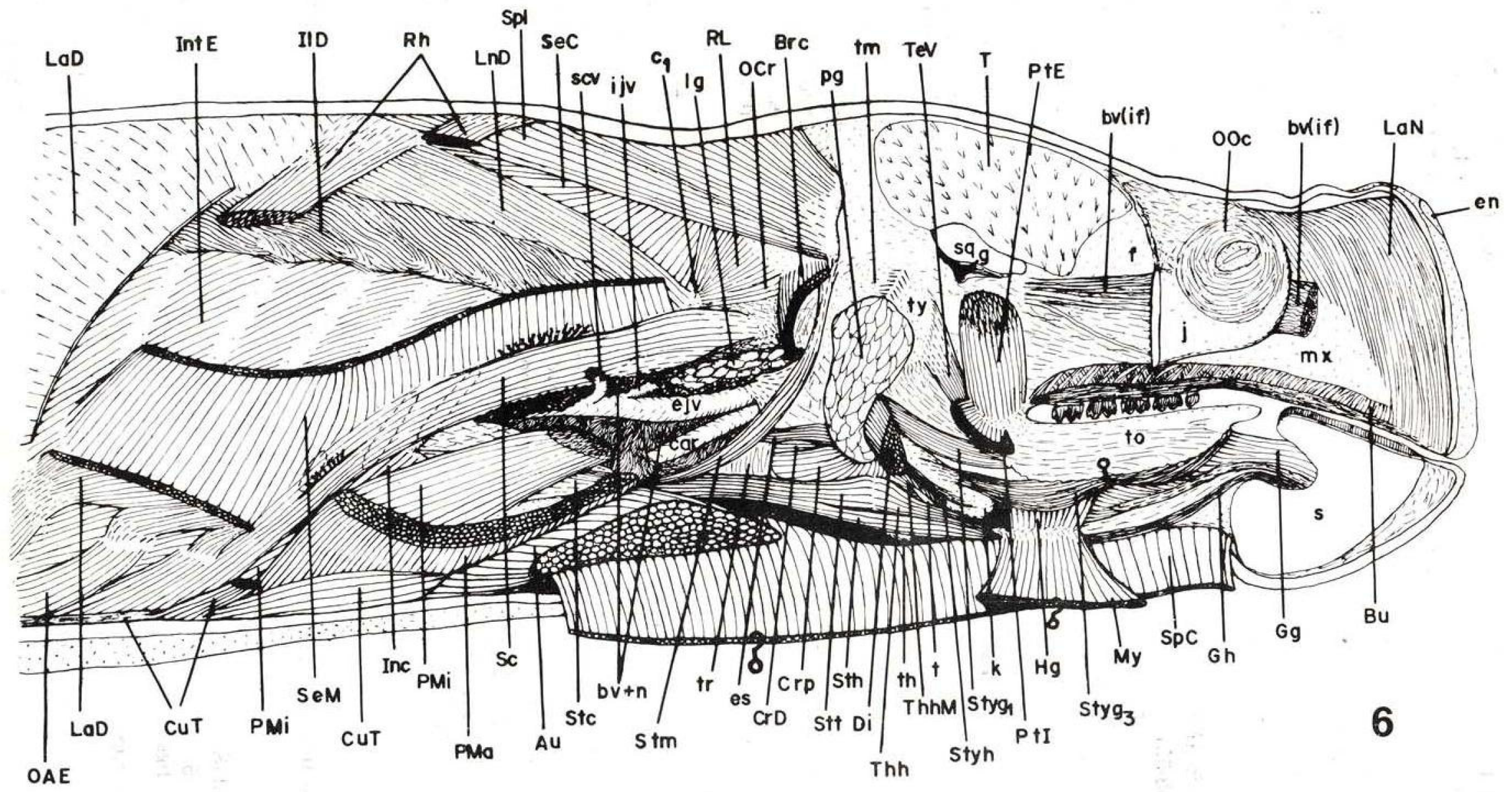

1 Fig. 6 - Lateral view of head, heck, and shoulder region; deep dissection with pectoral girdle and limb, right mandible, and most of right zygomatic arch

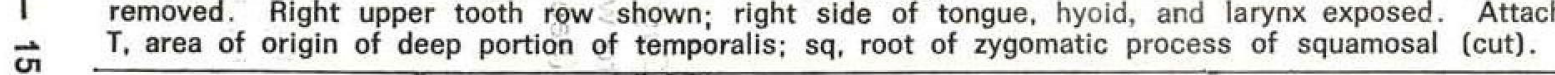


aligned fibers situated medially beneath the lower lip, was not observed as a distinct muscle, but may have been represented in INPA-PB 169 by some small fibers in connective tissue on either side of the tip of the mandible anterior to the mentalis and more or less vertical in orientation.

\section{MUSCLES OF THE JAWS}

- M. MASSETER (M: Figs. 3, 5, 11, 12, 14, 26, 46, 48-50):

(Murie, 1872: 151, figs. 10, 30: "masseter, Ma".)

ORIGIN: Tendinous from lateral and medial sides of suborbital process of jugal.

INSERTION: Fleshy and tendinous on rather narrow area along lateral edge of mandibular angle.

REMARKS: Complexly pinnate, but evidently without division as in Dugong.

\section{- M. ZYGOMATICOMANDIBULARIS (Z:}

Figs. $12,14,26,46,48-50$ ):

(Murie, 1872: 151, fig. 11: "masseter, Ma2".)

ORIGIN: Fleshy from ventral and medial sides of jugal from level of temporal condyle (posterior end of jugal) to just medial to posterior edge of masseter origin. Also has internal tendon of origin, lying in parasagittal plane.

INSERTION: Fleshy on oval area anteroventral to mandibular condyle on lateral side of ascending ramus. Lateral side of muscle has tendinous covering at insertion.

REMARKS: It appears that most of what I identified as the zygomaticomandibularis in Dugong (Domning, 1977a) in fact corresponds to what I here term the superficial temporalis (see below).

-M. TEMPORALIS: (T: Figs. 6, 10-12, 14, $15,24,45,48-50)$ :

(Murie, 1872: 151, figs. 8, 10.)

Both deep and superficial parts present, the latter separated from the zygomaticomandibularis by a vein and some small arteries.

ORIGIN: Deep part: Fleshy from entire surface of temporal fossa, limited by temporal crest, posterior end of supraorbital process, diagonal line (= crista intratemporalis) from latter to anterodorsal protuberance of alisphenoid, and dorsal side of root of zygomatic process of squamosal, and covering side of squamosal back to within $1 \mathrm{~cm}$ of sigmoid ridge. Anterior part covered by shining fascia, and containing tendinous sheets arising from crista intratemporalis and from protuberances ( $=$ orbicular apophyses) on side of temporal crest immediately abaft supraorbital process. Superficial part: Fleshy from dorsal side of zygomatic root and medial side of zygomatic process of squamosal as far forward as inward bulge on latter surface. In INPA-PB 14 the origins of the superficial and deep parts were continuous over the cranial surface of the squamosal. In INPA-PB 8, 9, and 169, however, they were quite separate, the medial edge of the superficial part lying along the medial boundary of the zygomatic root, and the lateral edge of the deep part lying along the parietal-squamosal suture, with most of the squamosal's surface exposed in the V-shaped space between. Thus the deep part arose aimost entirely from the frontal, parietal, and alisphenoid.

INSERTION: Fleshy and tendinous on coronoid process of mandible, deep part on its medial and superficial part on its lateral side. Anterior side of deep part has tendinous covering near insertion, parallel to internal sheets arising from orbicular apophyses and crista intratemporalis.

REMARK: The superficial part apparently corresponds to most of what I called the zygomaticomandibularis in Dugong (Domning, 1977a) .

- M. PTERYGOIDEUS EXTERNUS (PtE : Figs, 6, 11, 15, 47-50):

(Murie, 1872: 180.)

ORIGIN: Fleshy from ventral part of alisphenoid portion of pterygoid process; quite robust; parallel-fibered.

INSERTION: Fleshy on medial side of ascending ramus of mandible, just anteroventral to condyle. I could not be certain of any insertion onto the articular capsule or the articular disk. 
- M. PTERYGOIDEUS INTERNUS (PtI: Figs.

$6,11,12,15,47-50)$ :

(Murie, 1872: 180.)

ORIGIN: Fleshy and tendinous from posterior part of ventrolateral edge of pterygoid process; complexly pinnate.

INSERTION: Fleshy and tendinous on medial side of mandibular angle, covering most of area posteroventral to mandibular foramen and dental capsule.

-M. DIGASTRICUS (Di : Figs. 6, 14, 17-19, 26) :

(Murie, 1872: 180 figs. 9, 10, 30; Murie, 1880: pl. 8: fig. 5.)

ORIGIN: Fleshy and tendinous from posterolateral side of hyoid arch at stylohyoidepihyoid junction; no attachment to skull.

INSERTION: Fleshy on lower part of posterolaterad-facing posterior surface of mandible almost down to angle; thence lateral edge of insertion crosses this surface diagonally anteromediad to end at medial edge of angle adjacent to pterygoideus internus.
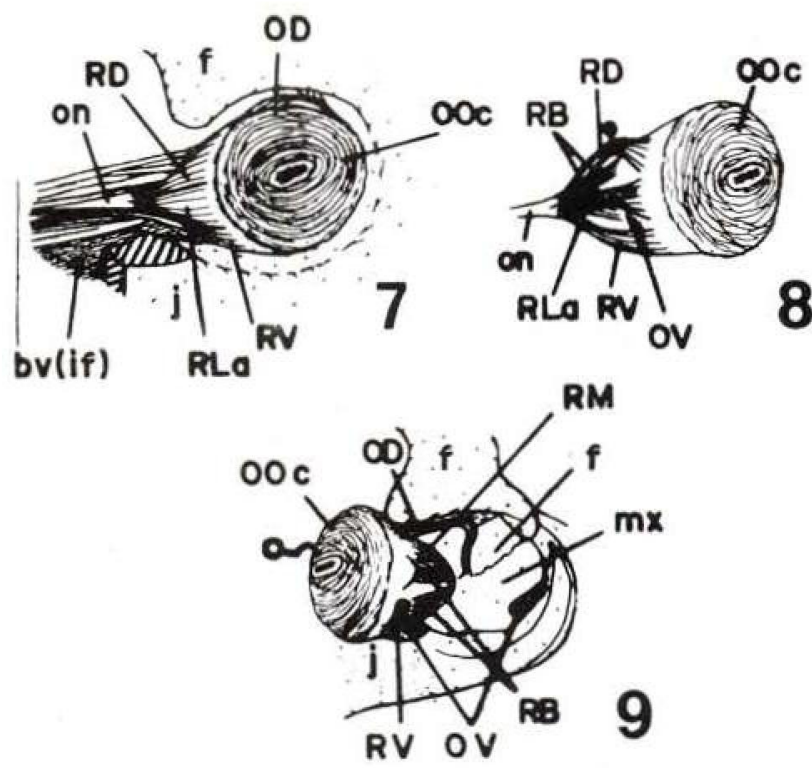

Figs. 7-9 - Extrinsic muscles of eyeball: 7, anterolateral view of right orbit, part of jugal removed to expose nerves and blood vessels passing toward infraotbital foramen; 8, lateral view of eyeball, $\mathrm{mm}$. recti retracted to expose deeper muscles: 9. anterolateral view of orbit, obliquus ventralis cut and eyeball pulled posterolaterad to show muscles on medial side.
REMARKS: Has only one belly (the anterior), as in other sirenians.

\section{MUSCLES OF THE MIDDLE EAR}

—M. TENSOR TYMPANI (TT: Figs. 12, 28):

ORIGIN: Tendinous and fleshy from posterolateral corner of base of pterygoid process at alisphenoid-pterygoid suture. Some fibers may also arise from posteromedial side of bony bridge connecting tympanic and tegmen tympani, as stated by Robineau (1969: 26) .

INSERTION: Passes posterolaterad through tympanic cavity as a stout cylindrical cord, closely adherent to bridge between tympanic and tegmen tympani, onto processus muscularis of malleus. Muscle consists mostly of tendinous fibers; only these are visible on its surface.

\section{STAPEDIUS (St: Figs. 12, 28) :}

ORIGIN : From fossa muscularis minor of periotic, posterolateral to fenestra ovale. Forms short, broad-based cone filling fossa; surface covered by shining fascia.

INSERTION: By very short tendon onto protuberance on posterior side of neck of stapes.

\section{EXTRINSIC MUSCLES OF THE EYEBALL}

\section{OBLIQUUS DORSALIS (OD: Figs. 7, 9) :}

ORIGIN: Tendinous from bony ridge along frontomaxillary suture (which forms medial wall of optic canal), at level of posterior edge of supraorbital process of frontal.

INSERTION: By tendon onto anterodorsal side of eyeball. Tendon is suspended from ventral side of tip of supraorbital process by a ligamentary band.

M. OBLIQUUS VENTRALIS (OV: Figs. $8,9,11)$

ORIGIN: Fleshy from anterior side of orbit near maxillojugal suture.

INSERTION: Passes ventrolaterad between rectus ventralis and eyeball to insert on latter deep to rectus lateralis. 
MM. RECTI LATERALIS, MEDIALIS, DORSALIS, ET VENTRALIS (RLa, RM, RD, RV: Figs. 7-9):

ORIGINS: From sheath of optic nerve, at about level of posterior edge of supraorbital process.

INSERTIONS: Broaden and diverge to tendinous insertions at the four sides of the eyeball, distal (cranial) to its equator.

REMARKS: Pütter (1902: 179-180, 185, 371) stated that the recti in the manatee and the dugong all arise behind the "optic foramen" rather than around it, contrary to my findings; however, Petit and Rochon-Duvigneaud (1929: 135) point out that the position of the optic nerve may change in the course of ontogeny.

M. RETRACTOR BULBI (RB: Figs. 8, 9): (Murie, 1872: 188: "choanoid".)

ORIGIN: In four parts (smaller than the recti), from sheath of optic nerve inside "sheath" formed by recti.

INSERTION : Around equator of eyeball, deep to recti; not alternating with them but rather almost directly beneath them.

REMARKS: Murie found "the remaining orbital muscles", i.e., the recti, "much weaker" than the retractor bulbi in $T$. manatus; Quiring and Harlan (1953: 194), however, stated that the retractor bulbi was absent in that species.

Murie (1872: 188) mentions a levator palpebrae, "obliquely directed inwards and downwards from the tarsal membrane", which I did not observe; this may, however, refer to the obliquus dorsalis, as Murie does not otherwise refer to the obliqui.

\section{TONGUE AND HYOID MUSCLES}

M. STYLOGLOSSUS (Styg $g_{1,3}$ : Figs. 6 , 16-21, 26) :

(Murie, 1872: 180, figs. 18, 37.)

Has only two divisions, corresponding to the "first" and "third" of Dugong, the "second" being absent or fused with the first.
—FIRST (Styg I $_{1}$ Figs. 6, 16-21):

ORIGIN: Fleshy and tendinous from anterolateral side of proximal end of hyoid arch, medial to digastricus. Tendon visible on muscle's lateral surface.

INSERTION: Fleshy and tendinous into posterolateral corner of tongue.

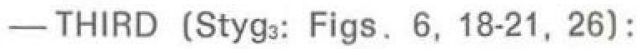

ORIGIN: Tendinous from lateral side of distal end of epihyoid.

INSERTION: Fleshy into whole length of ventrolateral side of tongue, lateral to hyoglossus and genioglossus.

M. HYOGLOSSUS (Hg: Figs. 6, 18, 20, 21, 26) :

(Murie, 1872: 180: distinct hyoglossus "not observed" in T. manatus.)

ORIGIN: With its fellow from median raphe attached to median tendinous portions of mylohyoideus and geniohyoideus.

INSERTION: Radiates laterad and anterolaterad to fleshy insertion into posterior part of ventrolateral side of tongue, medial to third division of styloglossus. A few fibers seemed to pass from posterior end of hyoglossus dorsad onto a transverse line across ventral side of basihyoid, but no attachment to thyrohyoid was observed as in Dugong.

M. GENIOGLOSSUS (Gg: Figs. 6, 15, 18, 21, 26) :

(Murie, 1872: 180: ? "genio-hyo-glossus".)

ORIGIN: Fleshy and tendinous from mental fossa on posterodorsal side of mandibular symphysis. A distinct, thick tendon runs along anterior part of muscle's ventral edge.

INSERTION: Fibers pass posterodorsad into ventral side of tongue, adjacent to midline and medial to hyoglossus and third division of styloglossus. The posteromost fibers form a broad bundle (not separable from rest) uniting posteriorly with its fellow in midline, and inserting into posteromost part of ventral side of tongue. This portion extends to just abaft insertion of first division of styloglossus, but does not reach hyoid as it does in Dugong. 

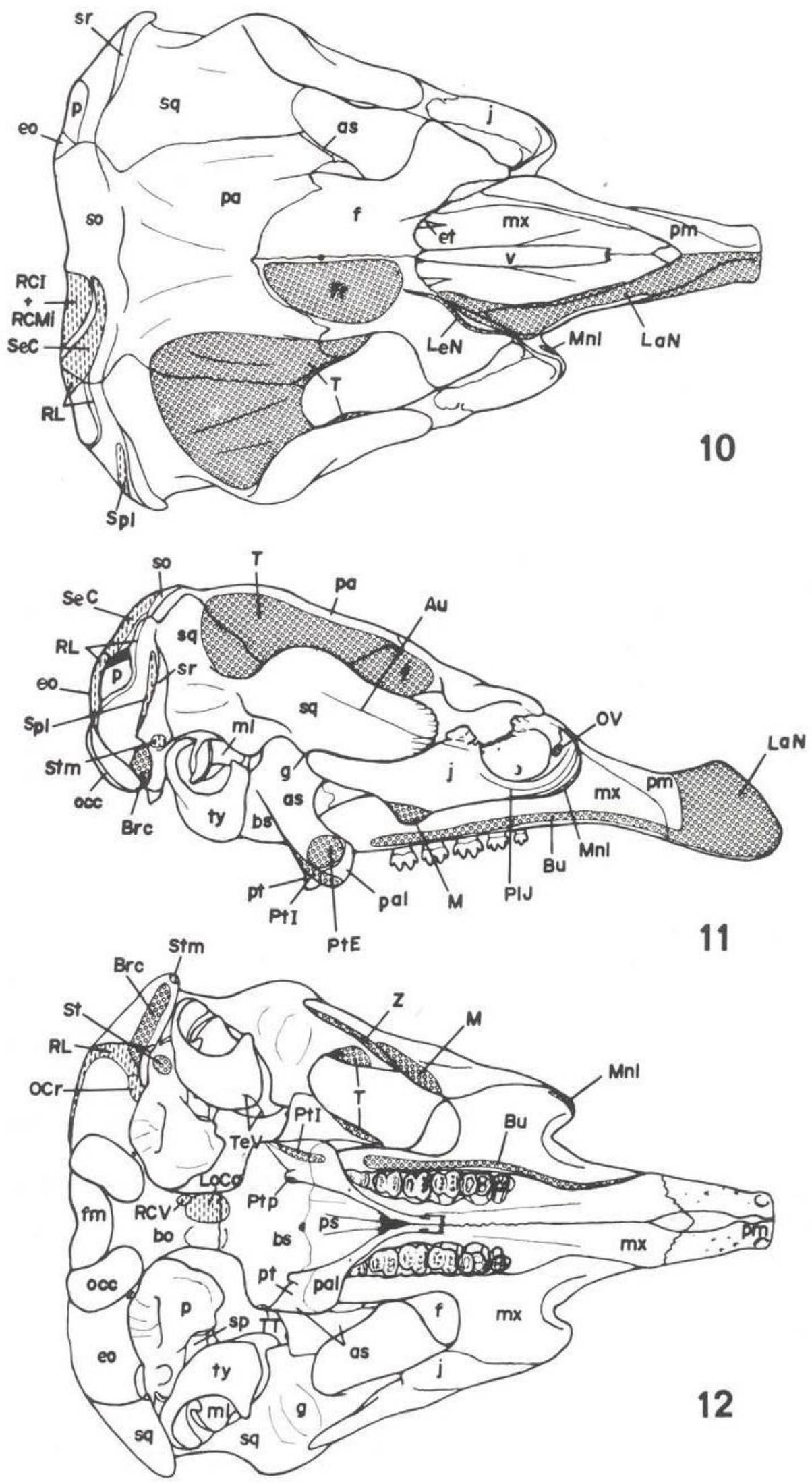

Figs. 10-12 - Dorsal, lateral, and ventral views of skull of juvenile Trichechus inunguis, showing bones and muscle attachments. 
The arrangement of muscle fibers within the tongue (Murie, 1872: 180: "lingualis"; Gudernatsch, 1909: 185-186) was not investigated in detail.

M. STERNOHYOIDEUS (Sth: Figs. 3, 6, 18, 26) :

(Stannius, 1845: 7; Murie, 1872: 179, fig. 9: "sterno-hyoid".)

ORIGIN: Fleshy from anterior part of dorsal side of manubrium, inseparable from sternothyroideus.

INSERTION: Runs forward, fused with sternothyroideus into narrow sheet of which sternohyoideus forms medial half. Anterior to thyroid cartilage it lies medial and parallel to, and slightly overlaps, thyrohyoideus, with which it is partly fused, finally inserting with it onto ventral side of median raphe to which mylohyoideus, hyoglossus, and geniohyoideus also attach. This junction is covered by the crescentic "submaxillary" salivary gland noted by Murie (1872: 173). There was no direct muscular attachment to the basihyoid, though Stannius says the muscle extends "to the hyoid bone".

REMARKS: This muscle was completely lacking in INPA-PB 9. Murie (1872: figs. 9, 30) likewise shows no separate band medial to the sternothyroideus and thyrohyoideus in $T$. manatus, nor does his text clarify whether a portion of the "sterno-hyoid" extends forward of the sternothyroideus insertion. The sternohyoideus also appears to be absent in Dugong (Domning, 1977a) .

Murie (1872: 179-180) reported "the anterior remnant" of an omohyoideus in $T$. manatus, but I have not observed this in $T$. inunguis or Dugong.

?M. THYROHYOIDEUS (Thh: Figs. 3, 6, $18-20,22,26)$ :

(Murie, 1872: figs. 9, 30: "thyro-hyoid".)

ORIGIN: Fleshy from side of thyroid cartilage anterior to insertion of sternothyroideus.

INSERTION: Runs forward as flat band lateral to and partly fused with sternohyoideus, and inserts with latter on median raphe of mylohyoideus, hyoglossus, and geniohyoideus.
From its medial edge an aponeurosis extends to posteromedial edges of basihyoid and thyrohyoid.

REMARKS: The form and attachments of this muscle agree in general with those described for the "thyrohyoideus" of $T$. manatus and Dugong. However, I also observed the following muscle, which may instead be the homolog of the thyrohyoideus of other mammals:

"M. THYROHYOIDEUS MINOR" (ThhM:

Figs. $6,16,18,19,20,22)$ :

ORIGIN: Fleshy from lateral side of cranial cornu of thyroid cartilage near its joint with thyrohyoid, and just forward of origin of thyropharyngeus.

INSERTION: Fleshy, in pinnate fashion, on anterior and posterior edges of thyrohyoid; belly covers attachment of latter to thyroid cartilage.

REMARKS: This muscle was observed in juvenile specimens (INPA-PB 6, 9, 14), but not in an adult (INPA-PB 117). I have found no record of a corresponding muscle coexisting with one similar to the above in any other mammal. It may be derived from the thyrohyoideus described above, or from the hyopharyngeus, which lies anterior and parallel to it.

M. MYLOHYOIDEUS (My: Figs. 3, 6, 15, 20, 21, 26):

(Murie, 1872: 180, fig. 30: "mylo-hyoid".)

ORIGIN: Fleshy from medial side of alveolar portion of mandible, from above mandibular foramen to midsection of tooth row (anterior end of tooth IV in animals with complete juvenile dentition).

INSERTION: Onto tendinous raphe in midline, together with and superficial to hyoglossus and geniohyoideus. Evidently no direct attachment to hyoid as in Dugong, thus agreeing with $T$. manatus.

Murie (1872: 179) found "keratic muscles" (keratohyoidei) "feebly represented" in $T$. manatus; these I did not observe. 


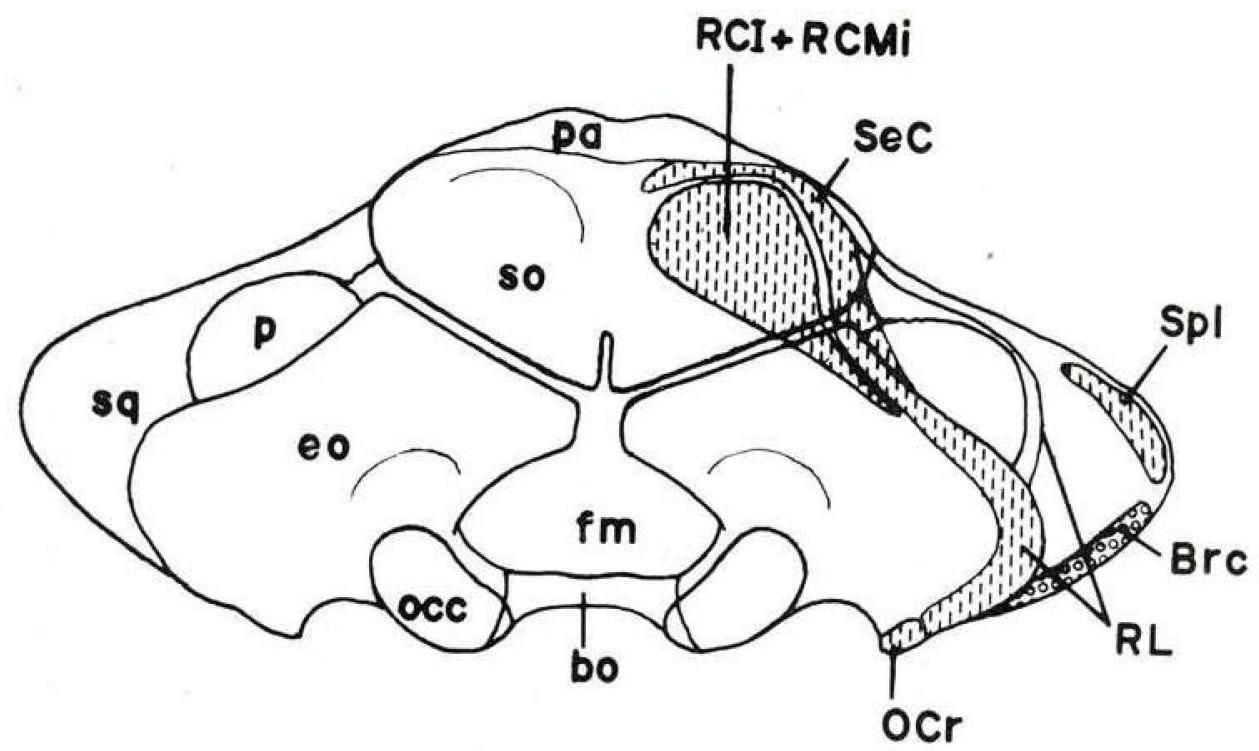

13
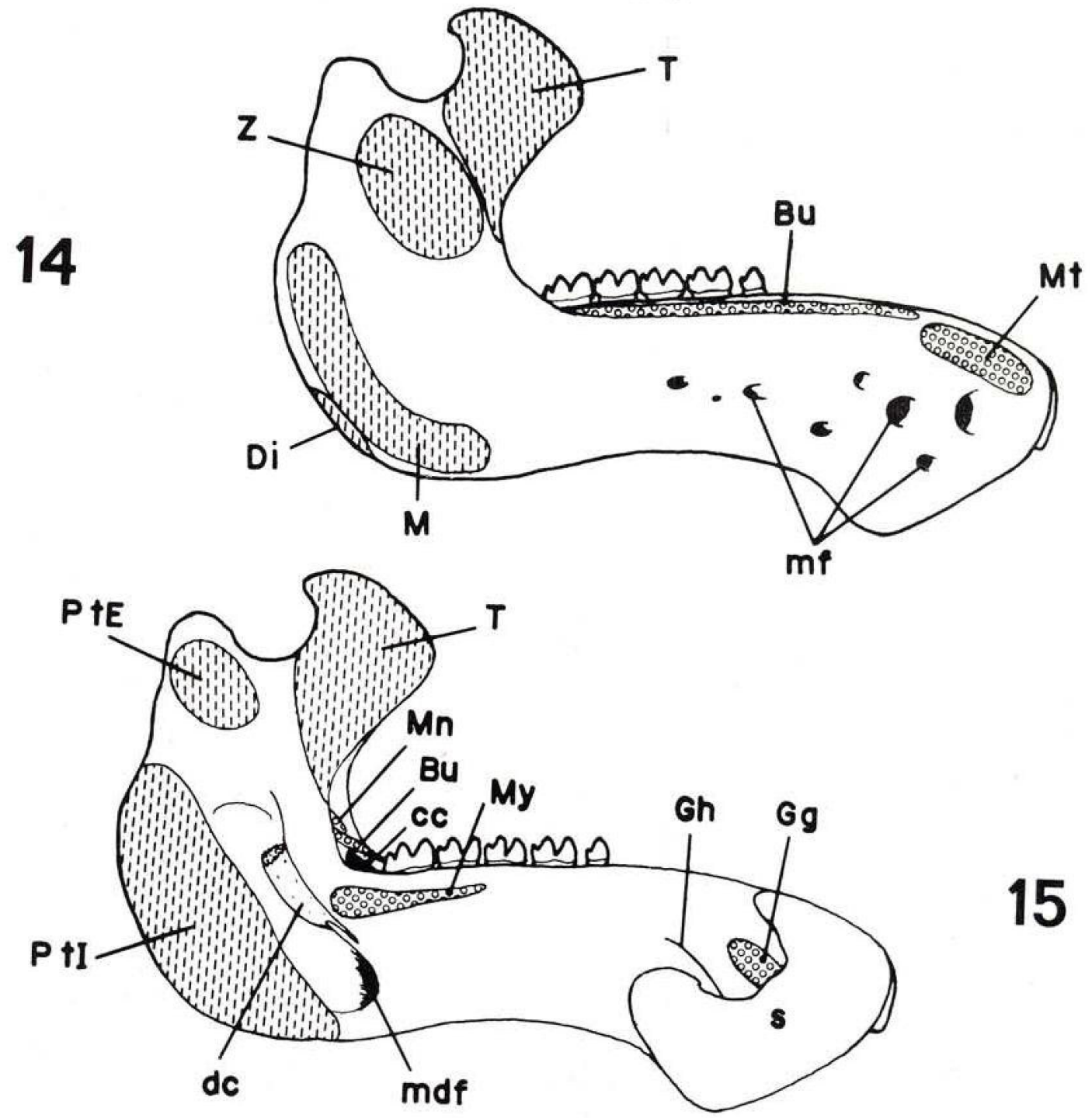

15

Figs. 13-15 - Skull and mandible of juvenile Trichechus inunguis, showing bones and muscle attachments : 13, posterior view of skull; $14-15$, lateral and medial views of mandible. 
M. GENIOHYOIDEUS (Gh: Figs. 3, 6, 15, 26) :

(Murie, 1872: 180.)

ORIGIN : By thin tendinous sheet from crescentic line (concave aft) across ventral side of mental fossa on posterodorsal side of mandibular symphysis, ventral to origin of genioglossus.

INSERTION: Continuous with fellow in midline; inserts on median raphe with hyoglossus and mylohyoideus.

REMARKS: Has no direct attachment to basihyoid, agreeing with Dugong but not $T$. manatus. The muscle forms a pouch enclosing a mass of fat in well-nourished animals.

M. STYLOHYOIDEUS (Styh: Figs. $6,18,19$ ): (Murie, 1872: 180, figs. 18, 30, 37.)

ORIGIN: Fleshy from posterolateral side of proximal end of hyoid arch. Distally, its thin belly is separated from hyoid by lingual artery.

INSERTION: Tendinous on ventrolateral surface of keratohyoid; tendon visible initially on lateral side of muscle.

REMARKS; In Dugong, inserts on basihyoid.

No jugulohyoideus was observed.

\section{MUSCLES OF THE PHARYNX}

M. HYOPHARYNGEUS (Hp: Figs. 16, 17, 20) :

ORIGIN: Fleshy from medial side of epihyoid, just ventral to eustachian tube. Thin and closely adherent to epihyoid.

INSERTION: Passes posterodorsad onto dorsal side of pharynx, where it is overlain by and inseparable from stylopharyngeus.

M. THYROPHARYNGEUS (Thp: Figs. 17, 18, 20-22) :

(Stannius, 1845: 30: ?"thyreoideus transversus"; Murie, 1872: 180, fig. 18: "constrictor superior", in part.)

ORIGIN: Fleshy from line along side of thyroid cartilage, dorsal to attachments of cricothyroideus, sternothyroideus, and thyrohyoideus and immediately anterior to origin of cricopharyngeus.
INSERTION : Onto middorsal raphe of pharynx with its fellow, overlapping cricopharyngeus.

M. CRICOPHARYNGEUS (Crp: Figs, 6, 17, $20,22,23)$ :

(Murie, 1872: 180, fig. 18: "constrictor superior", in part?)

ORIGIN: Fleshy from line along posterolateral edge of cricoid cartilage. The posteromedial bundles of fibers are rather loosely and irregulary spaced out, so that the cricoarytenoideus dorsalis is partly exposed posteromedially beneath the incomplete cricopharyngeus sheet.

INSERTION: Passes anterodorsad around front of esophagus and, with its fellow, onto middorsal raphe of pharynx, where it is crowded between esophagus and thyropharyngeus.

M. STYLOPHARYNGEUS (Styp: Figs. 16-18, 20):

(Murie, 1872: 180. figs. 18, 30.)

ORIGIN: Fleshy from medial side of stylohyoid.

INSERTION: Fleshy onto dorsolateral surface of nasopharynx, along line running diagonally posterodorsad from just abaft eustachian tube to midline.

REMARKS: No longitudinal division observed as in Dugong.

M. PTERYGOPHARYNGEUS (Ptp: Figs. 12, 20):

ORIGIN: Fleshy from medial side of posteroventral and medial (= pterygoid) extremity of pterygoid process.

INSERTION: Mingles with fibers of hyopharyngeus and stylopharyngeus on dorsolateral side of pharynx.

\section{MUSCLES OF THE SOFT PALATE}

M. TENSOR VELI PALATINI (TeV: Figs. $6,12,28)$ :

(Murie, 1872: 180: "tensor palati".)

ORIGIN: By wide flat tendon from antero. medial edge of tympanic and bridge connecting 


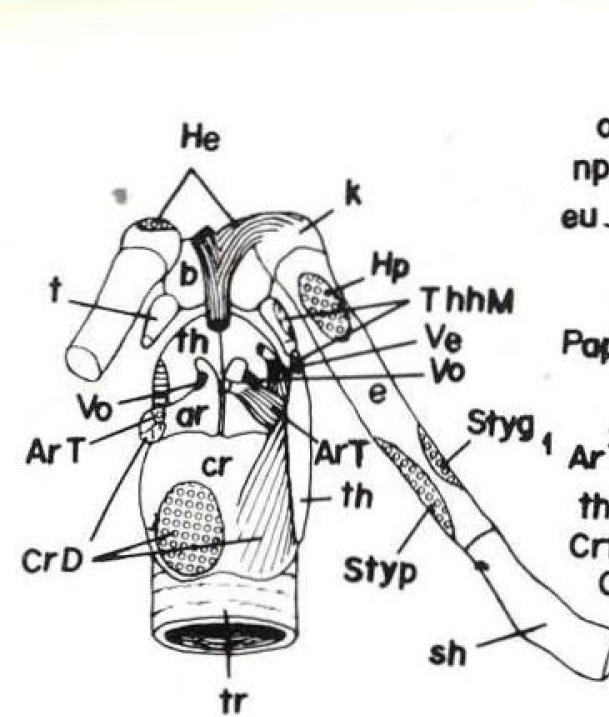

16

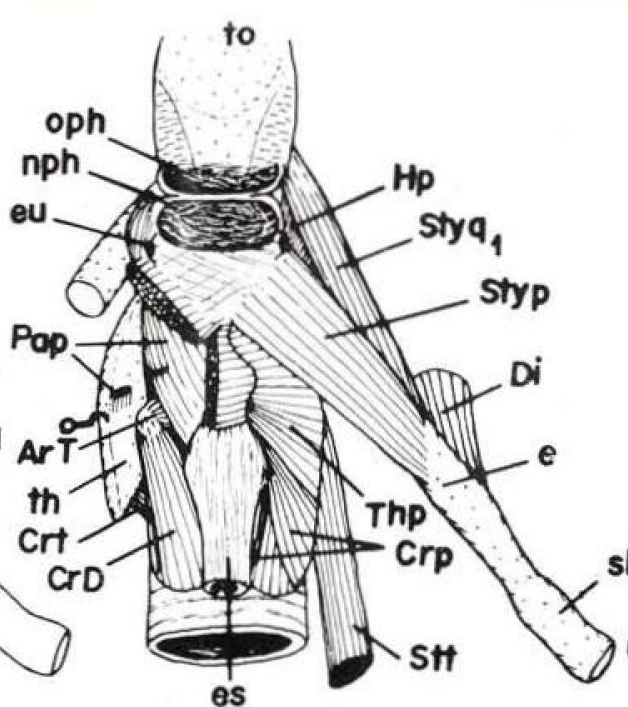

17

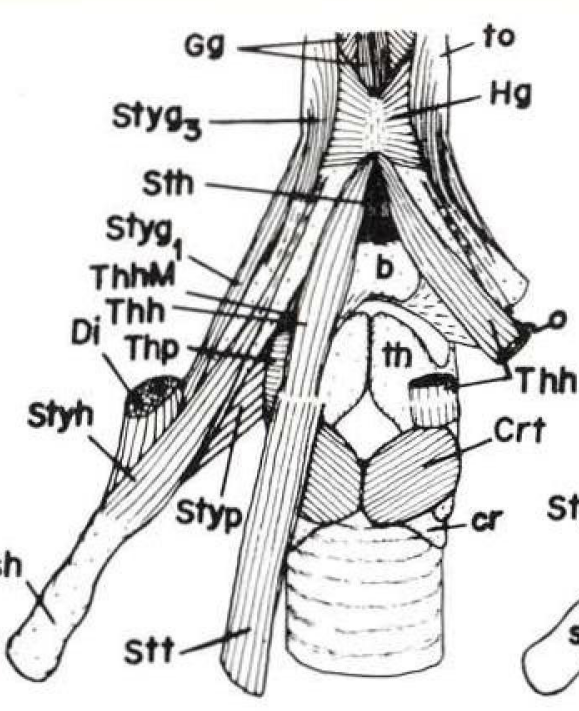

18
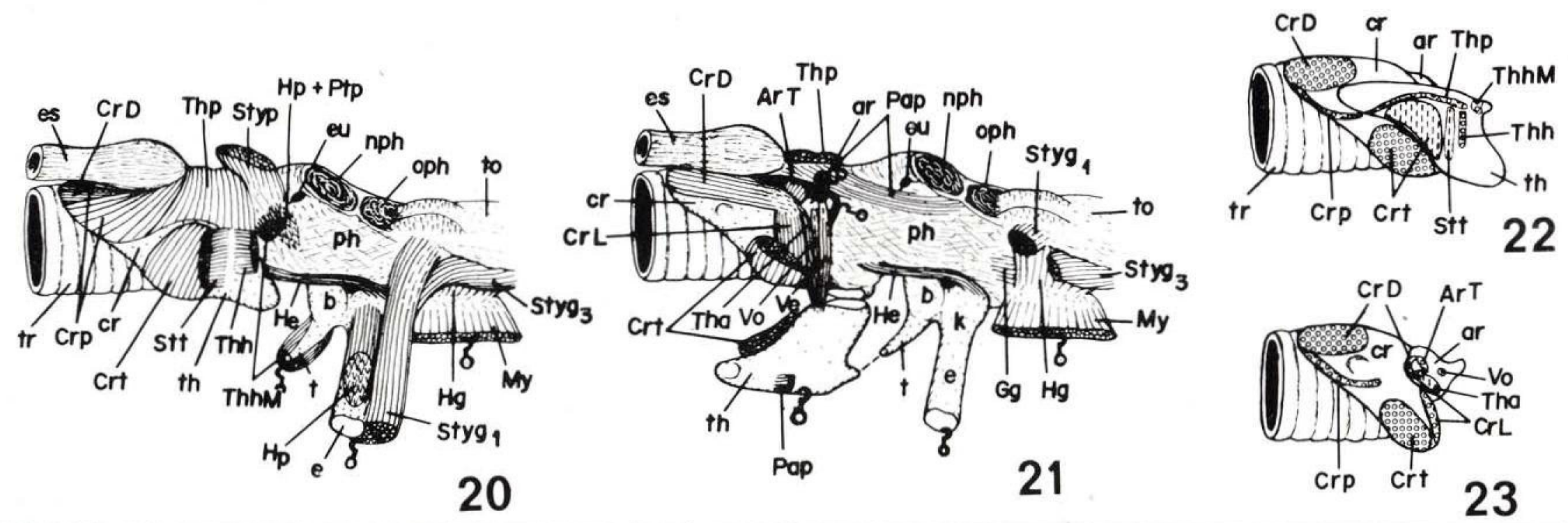

Figs. 16-23 - Hyoid arch, larynx, pharynx, and structures at base of tongue: 16, dorsal view of right and part of left hyoid arch, laryngeal cartilages, and deep muscles and muscle attachments; left wing of thyroid cartilage removed; 17, same view, showing muscles, base of tongue, and related structures; left wing of thyroid cartilage retracted and superficial muscles removed on left side; 18, ventral view of same structures; geniohyoideus, mylohyoideus, and parts of other superficial muscles removed; 19, ventral view of hyoid arch and laryngeal cartilages, showing muscle attachments; 20, right lateral view of larynx, pharynx, and base of tongue; right hyoid elements and attached muscles cut and pulled downward to expose side of pharynx; 21, same, superficial muscles removed and right wing of thyroid cartilage pulled downward to expose deep laryngeal muscles; 22, right lateral view of laryngeal cartilages, showing muscle attachments: 23, same, thyroid cartilage removed. 
latter to tegmen tympani, and tendinous from lateral and medial edges of fossa on posterior side of pterygoid process. Belly quite small and thin, its posteromedial side closely adherent to wall of tympanic cavity.

INSERTION: By thin tendon which passes anteromediad under trochlear surface of pterygoid process into soft palate.

REMARKS: Much smaller and weaker than observed in Dugong, though this may be due to the youth of the $T$. inunguis examined.

\section{PALATOPHARYNGEUS (Pap: Figs .} 17, 21) :

(Murie, 1872: 180.)

Very thin layer of fibers closely adherent to (indeed, virtually inseparable from) wall of nasopharynx. Fibers pass anterad and ventro. laterad across dorsal side of pharynx, beneath cricopharyngeus and thyropharyngeus, to edge of soft palate. Some fibers arise from dorsal edge of medial side of thyroid cartilage and pass anteromediad into palatopharyngeus.

REMARKS: This corresponds to what I identified as the aryepiglotticus in Dugong (Domning, 1977a) .

Murie (1872: 180) noted a palatoglossus and a levator veli palatini ("levator palati"), which I could not detect. I found no fibers (m. palatinus or $m$. uvulae) within the soft palate; Murie (1872: 173) also found no "appreciable uvular thickening of muscular fibres".

\section{MUSCLES OF THE LARYNX}

M. CRICOTHYROIDEUS (Crt: Figs. 3, 17-23, 26) :

(Murie, 1872: fig. 30: "crico-thyroid".)

ORIGIN: Fleshy from posteroventral side of cricoid cartilage. May be asymmetrical; in INPA-PB 117, origin of left muscle extended well to right of midline on posterior edge of cricoid cartilage.

INSERTION: Fleshy on posterolateral side of thyroid cartilage, ventral to origin of thyropharyngeus and posterior to insertion of sternothyroideus.
M. CRICOARYTENOIDEUS DORSALIS (CrD:

Figs. 6, 16, 17, 20-23) :

(Murie, 1872: 180, fig. 18: ?"constrictor medius".)

ORIGIN: Fleshy from dorsal side of cricoid cartilage, largely covered by cricopharyngeus.

INSERTION: Passes forward lateral to esophagus to fleshy insertion on posterior side of muscular process of arytenoid cartilage.

\section{CRICOARYTENOIDEUS LATERALIS (CrL:}

Figs, 21,23):

ORIGIN: Fleshy from lateral and medial sides of anterolateral edge of cricoid cartilage.

INSERTION: Fleshy on ventral side of muscular process of arytenoid cartilage.

M. THYROARYTENOIDEUS (Tha: Figs. 21, 23) :

ORIGIN: Tendinous from posteromedial corner of dorsal (inner) side of transverse part of thyroid cartilage, adjacent to midline, together with vocalis and ventricularis.

INSERTION: Fleshy on anteroventral side of muscular process, and lateral side of ventral process, of arytenoid cartilage.

?M. VOCALIS (Vo: Figs. 16, 21, 23):

ORIGIN: Fleshy from thyroid cartilage together with and inseparable from thyroarytenoideus and ventricularis, and anterior and medial to them, respectively.

INSERTION: Tendinous and fleshy on lateral side of corniculate process of arytenoid cartilage.

\section{?M. VENTRICULARIS (Ve: Figs. 16, 21):}

ORIGIN: Fleshy from thyroid cartilage, inseparable from thyroarytenoideus and vocalis. Passes dorsad lateral to vocalis.

INSERTION: By flat tendon into roof of pharynx dorsal to arytenoid cartilage.

REMARKS: Though not previously described, the two foregoing muscles are presumably present in other sirenians as well as $T$. inunguis. They are clearly derivatives of the original thyroarytenoid muscle mass. 


\section{ARYTENOIDEUS TRANSVERSUS (ArT :}

Figs. 16, 17, 21, 23):

ORIGIN: Fleshy from anterodorsal side of muscular process of arytenoid cartilage.

INSERTION: Onto short tendon joining it with its fellow in midline between arytenoid cartilages and esophagus.

REMARKS: No median cartilage observed at insertion as in one Dugong (Owen, 1838: 38) .

Concerning the above muscles in $T$. manatus, Murie (1872: 179) says only that "each and all of the laryngeal muscles are relatively well developed. The extrinsic laryngeal muscles maintain a fair size, with attachments of the ordinary kind".

M. HYOEPIGLOTTICUS (He: Figs. 16, 19-21):

(Stannius, 1845: 30; Murie, 1872: 179: "hyoepiglottidei" absent in T. manatus.)

ORIGIN: Fleshy from anteromedial surface of keratohyoid.

INSERTION: Muscles from each side quickly join and pass posterodorsad as single median bundle into ventral side of epiglottis. In INPAPB 117, some fibers inserted on anteroventral edge of thyroid cartilage.

REMARKS: Though Stannius found this muscle to be "very weak" in $T$. inunguis and Murie failed to find it at all in $T$. manatus, it was well developed here and in Dugong, where it seems to have the same structure.

An aryepiglotticus was not observed, much less the "superior and inferior aryteno-epiglottidei" differentiated by Murie (1872: 179) in $T$. manatus. What I identified as an aryepiglotticus in Dugong (Domning, 1977a) was evidently the palatopharyngeus (q.v.). The thyroepiglotticus noted by Murie (1872: 179: "thyro-epiglottideus") was also not observed.

\section{DORSAL MUSCLES OF THE TRUNK}

M. SPLENIUS (Spl: Figs. 1, 5, 6, 10, 11, 13, 24, 25):

(Murie, 1872: 145, fig. 8.)

ORIGLN : By aponeurosis from dorsal midline, from nuchal line back to tip of neural spine of fifth thoracic vertebra.
INSERTION: Tendinous and fleshy on lateromost part of posterior side of sigmoid ridge of squamosal. Fibers do not attach to the broad surface $(\sim 2 \mathrm{~cm}$ wide) formed behind sigmoid ridge by squamosal and exposed periotic; this is covered by a single layer of vascular rete overlain by splenius.. In INPAPB 6, inserted on whole length of sigmoid ridge up to dorsal edge of squamosal.

REMARKS: Murie's account of $T$. manatus seems to indicate that the splenius arises from the surface of the semispinalis capitis, which is unlikely, and he states that it inserts "into the exoccipital ridge", which is surely an error. Conditions in Dugong agree exactly with those in $T$. inunguis.

\section{EPAXIAL SPINAL MUSCULATURE}

As in Dugong, the epaxial muscles of the manatee are fused into a continuous mass extending from the occiput to the tip of the tail. This is composed of the almost inseparable transversospinalis and longissimus systems; the iliocostalis remains distinct.

\section{Transversospinalis System}

In addition to multifidus and shorter fascicles, the largely undifferentiated transversospinalis includes the following semispinalis portions :

M. SEMISPINALIS CAPITIS (SeC: Figs . $6,10,11,13,24,25,29)$ :

(Murie, 1872: 145, fig. 8: "complexus".)

ORIGIN: Arises in fusion with epaxial mass out of cleft between semispinalis and longissimus dorsi; separated from latter by cleft reaching back to fourth thoracic vertebra. Tendinous and fleshy slips arise from lateral edges of zygapophyses of cervicals $3-6$ and from protuberances on dorsal sides of transverse processes of thoracics 1-7.

INSERTION: By strong tendinous sheet onto nuchal line from midline to edge of supraoccipital. Tendon lies on deep side of muscle medially, but laterally becomes exposed on superficial side as well. At edge of supraoccipital, a fleshy fold of semispinalis capitis 

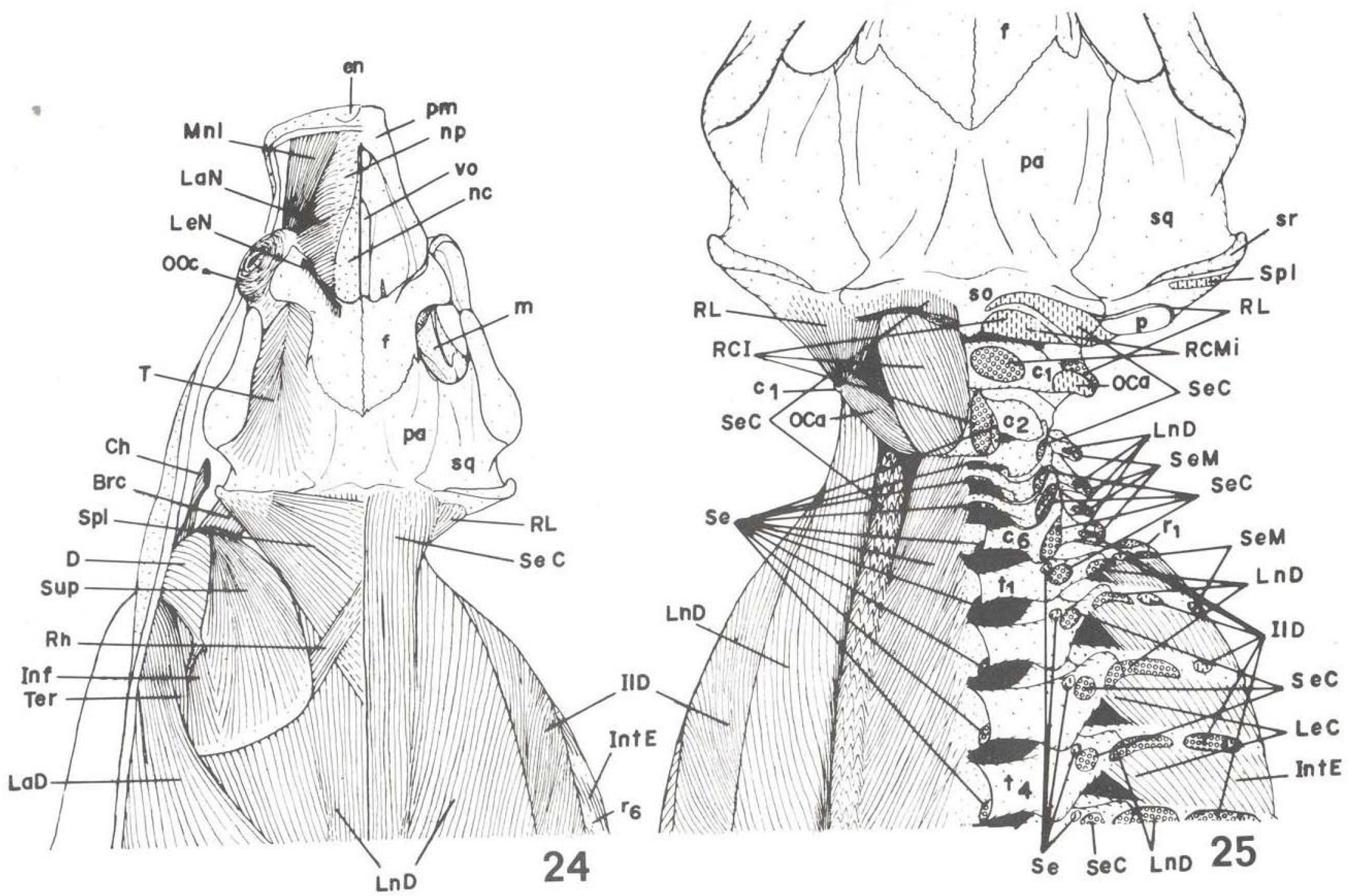

Figs. 24-25 - Dorsal views of head and neck region: 24, left side, deep muscles of snout, temporalis, and muscles of neck and shoulder with cutaneus trunci and trapezius removed; right side, pectoral girdle, limb, and attached muscles removed; 25 , left side, deep muscles of neck and anterior thorax, with most of semispinalis capitis removed; right side, attachments of cervical, epaxial, and related muscles. Transversospinalis fibers shorter than semispinalis not shown. 
overlaps and is continuous with fleshy insertion of rectus capitis lateralis onto posterodorsal corner of squamosal and exoccipital border.

REMARKS: Dorsolateral side of muscle has longitudinal cleft near midline at level of thoracics 2-3; this may be a vestige of a division into biventer cervicis and complexus portions.

M. SEMISPINALIS (Se: Fig. 25) :

(Murie, 1872: 144; Slijper, 1946: tabs. 3, 6.)

ORIGIN: Tendinous and fleshy from posterolateral corner of neural spine of axis, medial parts of dorsal sides of cervical neural arches 3-6, and posterolateral processes of tips of neural spines of first thoracic and following vertebrae. In young animals, forms strong, distinct bundles in neck region.

INSERTION: Tendinous on metapophyses of first thoracic and following vertebrae, medial to semispinalis capitis

In trunk region, transversospinalis fibers arise from deep side of spinous tendinous sheet of longissimus dorsi and pass posterolaterad to insert on dorsal side of metapophysial sheet. At level of eighth postthoracic vertebra, origins from spinous sheet end and latter becomes free from underlying muscle. Insertion on metapophysial sheet continues to about postthoracic 19. Fleshy origins from medial parts of dorsal sides of vertebral centra continue into posterior caudals, and insertions onto dorsal sides of centra continue to end of tail. A $\mathrm{m}$. spinalis is absent, as stated by Slijper (1946: tabs. 3, 6); the "combined or continuous spinalis dorsi and levator caudae internus" described by Murie (1872: 144, fig. 39) merely refers to the transversospinalis complex as a whole (see Slijper, 1946: 77).

\section{Longissimus System}

A longissimus capitis is absent, in contrast to $T$. manatus (Murie, 1872: 144-145: "trachelomastoid") and Dugong. Slijper (1946: 75) does not mention its occurrence in the Trichechus which he studied.
M. LONGISSIMUS DORSI (LnD: Figs. 1, 2, $6,24,25,29,37)$ :

(Murie, 1872: 144, figs. 8, 39: "transversalis colli" + longissimus dorsi", including "levator caudae externus"; Slijper, 1946: 47, 74, 76, 112, tab. 3.)

ORIGIN: Tendinous and fleshy from posterior side of transverse process of atlas and dorsolateral sides of transverse processes of cervicals 3-6; fleshy from posterodorsal sides of ribs 1-15 medial to iliocostalis dorsi; tendinous and fleshy from posterolateral corners of transverse processes of thoracics 1-15; and fleshy from dorsal sides of transverse processes of thoracic 8 through postthoracic 18.

INSERTION: By aponeurosis (exposed dorsally from thoracic $7 \mathrm{aft}$ ) onto tips of neural spines from thoracic 8 to end of tail. In pos. terior part of tail, tendinous fibers are gathered into more or less distinct cords or bundles. Laterally, fibers insert on both sides of this spinous aponeurosis, which begins inside the muscle at about level of thoracic 5 and whose lateral edge lies about halfway across the muscle's width. Where this spinous sheet becomes dorsally exposed and at about level of thoracic 6, it gives off from its deep side a metapophysial aponeurosis which inserts on metapophyses of thoracic 7 through postthoracic 7 and (farther aft where metapophyses are not developed) on dorsolateral sides of centra back to about postthoracic 19 .

REMARKS: Not fused with iliocostalis dorsi, though their edges are closely adherent back to about the third rib. Slijper (1946: tab. 3) found both the spinous and the metapophysial sheets inserting on all vertebrae from thoracic 6 to the end of the tail.

\section{Iliocostalis System}

M. ILIOCOSTALIS DORSI (IID: Figs. 1, 2, $6,24,25,29$ ) :

(Murie, 1872: 144, fig. 8: "cervicalis ascendens" + "sacro-lumbalis"; Slijper, 1946: 46, 47, 73-74, tab. 3.)

ORIGIN: By thin, wide tendons from lateral sides of ribs $4-15$, just distal to their angles and beneath middle of muscular strip formed by iliocostalis. Fibers seem to arise from both 
medial and (especially) lateral sides of these tendons. Posterior to last rib, iliocostalis arises fleshily and tendinously from aponeurosis on ventrolateral edge of longissimus dorsi as far back as level of postthoracic 5; its fibers sweep anteroventrad across surface of intertransversarius (to which they adhere), then anterodorsad onto side of rib 15. In INPA-PB 6 , arose posteriorly as thin bundle running along dorsal edge of intertransversarius as far back as level of caudal peduncle, where it fused with intertransversarius.

INSERTION: Tendons pass anteroventrad to insert on posterior sides of ribs at lower edge of iliocostalis, about four ribs forward of their origins, and on dorsal side of transverse process of cervical 6 with longissimus dorsi. In INPA-PB 6, extended forward to about cervical 3. Fibers insert pinnately on lateral sides of these tendons. On lateral surface of muscle, tendons of insertion visible for about $1 \mathrm{~cm}$ abaft insertions.

REMARKS: Murie found an extension of this muscle forward to the axis. The posterior part of the iliocostalis overlapping the intertransversarius agrees with his observation on $T$. manatus, in contrast to Dugong. This posterior portion is apparently the "ilio-costalis lumborum" of Slijper (1946: 47, 73-74). Accordingly I have used the term "iliocostalis dorsi ${ }^{n}$ for the entire muscle in preference to "iliocostalis thoracis" which I used in the case of Dugong, where this portion is absent (Domning. 1977a). Slijper states that in Trichechus the "ilio-costalis lumborum" is completely free from the longissimus, which is essentially true, the very limited attachment I found at the former's posteromost end hardly being a significant exception. There is, of course, no attachment to the pelvis.

\section{DEEPER MUSCLES OF THE NECK}

M. RECTUS CAPITIS DORSALIS ?INTERMEDIUS (RCl: Figs. 10, 13, 25):

(Murie, 1872: 145: "rectus capitis posticus major".)

ORIGIN: Fleshy from apex of axis adjacent to midline.
INSERTION: Fleshy on supraoccipital in fusion with rectus capitis dorsalis minor.

REMARKS: Quite robust. The much smaller muscle which I identified as a rectus capitis dorsális ?major in Dugang (Domning, 1977a) is absent in $T$. inunguis or fused with this muscle. As the muscle in the manatee resembles in size and relationships that which I called the rectus ?intermedius in Dugong, I use that name instead of "rectus ?major".

\section{RECTUS CAPITIS DORSALIS MINOR} (RCMi: Figs. 10, 13, 25) :

(Murie, 1872: 145: "rectus capitis posticus minor".)

ORIGIN: Fleshy from dorsal side of atlas adjacent to midline.

INSERTION: Fused with rectus capitis dorsalis intermedius into fleshy mass more than $1 \mathrm{~cm}$ thick, which has fleshy insertion on dorsolateral part of posterior surface of supraoccipital medial to semispinalis capitis, and inserts by short tendinous sheet on posterior edge of dorsal half of exoccipital flange medial to fused semispinalis capitis and rectus capitis lateralis.

M. RECTUS CAPITIS LATERALIS (RL: Figs. $6,10-13,24,25,28,29$ ):

(Murie, 1872: 145, fig. 29: "rectus lateralis"; Murie, 1880: 34, pl. 8: fig. 5.)

ORIGIN: Fleshy and tendinous from anterodorsal side of transverse process of atlas.

INSERTION: Fleshy on exoccipital flange, continuous dorsally with semispinalis capitis and ventrally with obliquus capitis cranialis; also inserts on posterodorsal corner of squamosal and along mastoid notch via aponeurosis covering mastoid foramen. Exoccipital flange is thus almost entirely occupied by fibers arising from transverse process of atlas. No fibers seem to reach stylohyoid, in contrast to $T$. manatus.

REMARKS: Strikingly different from $T$. manatus and Dugong is the expansion here of the rectus capitis lateralis into a fanlike sheet covering the entire dorsolateral border of the exoccipital and continuous at its insertion with the semispinalis capitis 
M. RECTUS CAPITIS VENTRALIS (RCV:

Figs. 12, 28):

(Murie, 1872: 147, fig. 29: "rectus (capitis)

anticus minor"; Murie, 1880: 34, pl. 8: fig. 5.)

ORIGIN: Rather thin band with fleshy and tendinous origin from ventrolateral side of atlas, ventromedial to transverse process.

INSERTION: Fleshy on posterolateral part of occipitosphenoidal eminence, deep to and posterolateral to insertion of longus capitis.

\section{OBLIQUUS CAPITIS CAUDALIS IOCa:}

Fig. 25):

(Murie, 1872: 145: "obliquus inferior".)

ORIGIN: Fleshy from neural arch of axis, at side of posterolateral corner of apex.

INSERTION: Fleshy on posterodorsal side of transverse process of atlas.

M. OBLIQUUS CAPITIS CRANIALIS (OCr:

Figs. $6,12,13,28$ ):

(Murie, 1872: 145: "obliquus superior"; Murie, 1880: 34 , pl. 8 : fig. 5 .)

ORIGIN: Fleshy from anteroventral side of atlas, ventromedial, to rectus capitis lateralis.

INSERTION: Fleshy on ventrolateral corner of exoccipital, ventromedial to and nearly inseparable from rectus capitis lateralis, and closely related to medial end of origin of brachiocephalicus and to proximal end of hyoid arch.

M. STERNOMASTOIDEUS (Stm: Figs. 6, 11, 12, 26, 29) :

(Murie, 1872: 152-153, figs. 9, 29, 30; Murie, 1880: pl, 8: fig. 5.)

ORIGIN: Fleshy from ventral side of manubrium, adjacent to midline and anterior to and continuous with origin of pectoralis major.

INSERTION: By strong tendon into pit on ventral end of sigmoid ridge of squamosal. A substantial sheet of fascia binds distal end of muscular portion of sternomastoideus to region of carotid and jugular vessels behind parotid gland, but this is not a "division" of the muscle as described by Murie.

REMARKS: Does not penetrate parotid gland as it does in $T$. manatus. Stannius (1845: 34), in asserting connection of this muscle with the deltoideus, mistook the cephalohumeralis for the sternomastoideus.

M. STERNOTHYROIDEUS (Stt: Figs. 3, 6, 17-20, 22, 26) :

(Murie, 1872: 179, fig. 9.)

ORIGIN: Fleshy from first costal cartilage and adjacent deep side of manubrium, together with and lateral to but inseparable from sternohyoideus.

INSERTION: Fleshy on lateral side of thyroid cartilage, forward of cricothyroideus insertion and abaft origin of thyrohyoideus.

REMARKS: Has no tendinous divisions.

M. SCALENUS (Sc: Figs. 6, 26, 28, 29):

(Stannius, 1849: 36; Murie, 1872: 152, fig. 29; Murie, 1880: 35, pl. 8: fig. 5.)

ORIGIN : Large superficial part arises fleshily from anterior ribs in following fashion: from anterior edge of rib 1 except for its distal end; from side of distal half of rib 2 nearly to its distal end, and continuous dorsally with serratus magnus; from a smaller area farther from distal end of rib 3 ; and arising from and continuous with fibers of obliquus abdominis externus ventral to distal end of rib 4 . Latter portion passes over end of rib 3 distal to fibers arising therefrom, and separated from them by a cleft through which emerge several small blood vessels. (This slip could also be considered an extension of the obliquus abdominis externus to rib 2.) Anterior to rib 2, scalenus separated from serratus magnus by similar cleft through which emerges a larger vascular rete. Small deep part of scalenus, separable from superficial part and itself in two partly separable (proximal and distal) parts, has fleshy origin from proximal half of anterior edge of rib 1 .

INSERTION: Bulk of scalenus has tendinous and fleshy insertion on posterior side of transverse process of atlas. Strong tendon visible on ventral edge of anterior end of muscle divides into distinct tendons leading to ventrolateral corners of transverse processes of cervicals 2-3 (none observed on cervical 4). There may also be more dorsal tendinous 


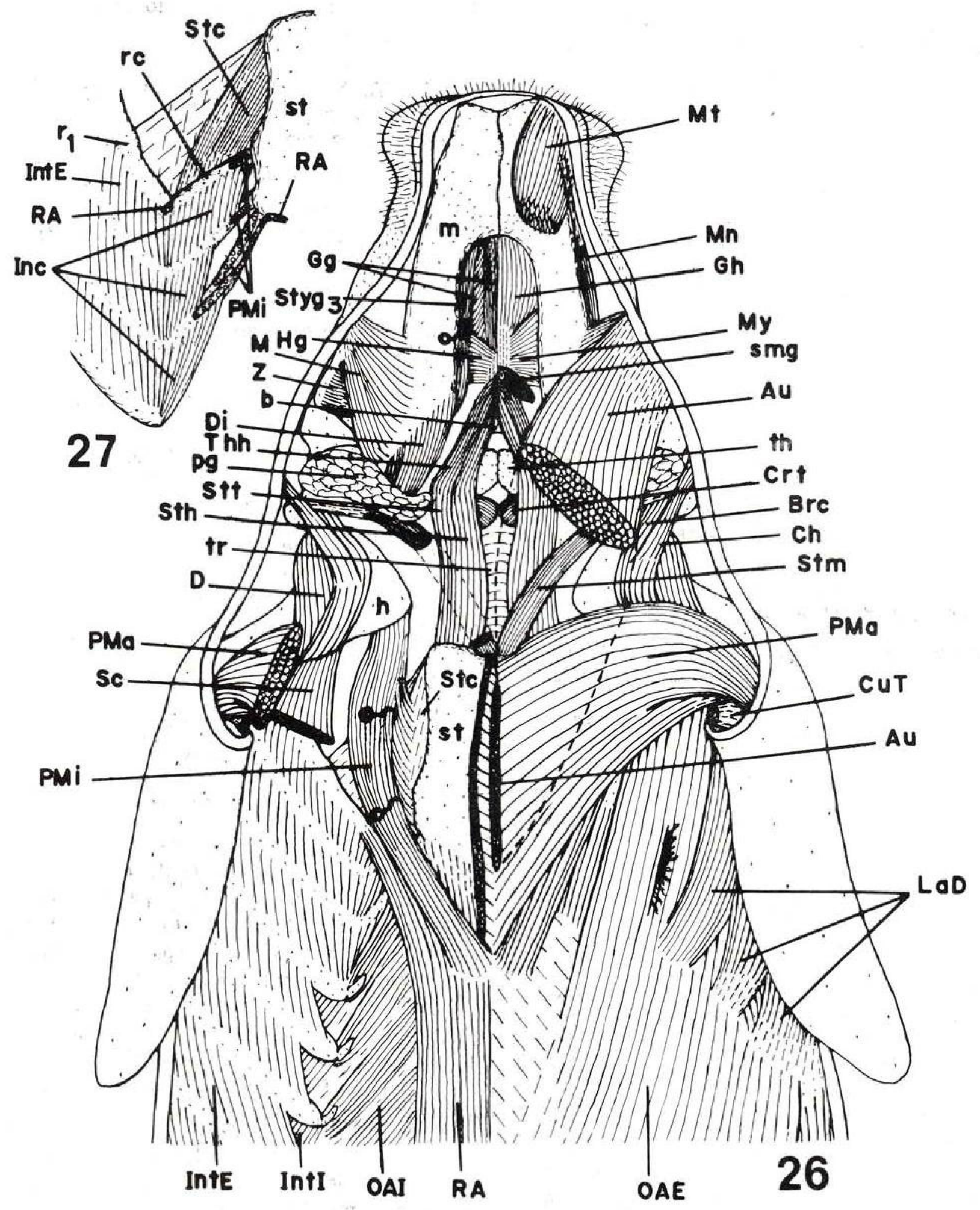

Figs. 26-27 - Ventral views of head, neck, and chest: 26, left side, sphincter colli superficialis, cutaneus trunci, and most of sphincter colli profundus pars auris removed (outline of latter dashed); right side, deeper dissection, exposing genioglossus, jaw muscles, sternum, attachments of pectoralis minor, and deeper thoracic and abdominal muscles; 27, muscles of right costal cartilages. 
insertions, in union with serratus magnus, on cervicals 3-5 and possibly 6. Deep parts of scalenus have tendinous and fleshy insertions on ventrolateral corner of transverse process of cervical 4 (5 also in INPA-PB 8 , and 6 in INPA-PB 6).

REMARKS: Stannius states that the superficial scalenus ("scalenus posticus") attaches only to the first two ribs in Trichechus, and that a deep portion ("scalenus anticus") appears to be lacking altogether. Murie, however, found both, with rib attachments similar to those described above, though the cervical attachments differed in detail; in his first specimen an insertion on the atlas was even lacking. Clearly these attachments are highly variable, due to the reduction of the neck. The muscular slips to the vertebrae do not form separate bundles here as illustrated by Murie.

\section{LONGUS CAPITIS (LoCa: Figs. 12, 28,} 29) :

(Murie, 1872: 147-148, fig. 29: "rectus (capitis) anticus major"; Murie, 1880: 34, pl, 8: fig. 5 )

ORIGIN: By tendinous sheet from surface of lateral part of longus colli, from lateral part of ventral side of centrum of first thoracic vertebra, and from ventral side of tip of capitulum of first rib. On left side of INPA-PB 14 , lateral edge of muscle also had tendinous origin from ventral side of transverse process of cervical 5. Muscle has form of flat band at origin, becoming more cylindrical toward insertion.

INSERTION : Fleshy and tendinous on occipitosphenoidal eminence of skull. A few fibers also pass onto surface of longus colli at about level of cervicals 3 and 4 .

REMARKS: The vertebral attachments here agree with those in Murie's second (1880) dissection of $T$. manatus rather than his first (1872), in which the muscle extended as far back as the second rib and the third thoracic vertebra.

M. LONGUS COLLI (LoCo1-3: Fig. 28) : (Murie, 1872: 147, fig. 29; Murie, 1880: 34, pl. 8: fig. 5.)

Thin sheet covering ventral sides of cervical vertebrae; imperfect division into three parts as follows, proceeding mediad:
- FIRST $\left(\mathrm{LoCo}_{1}\right)$ :

Most distinct (anteriorly) and most lateral part.

ORIGIN: Fleshy and tendinous from lateral parts of ventral sides of cervical centra 2-6.

INSERTION: Fleshy onto ventrolateral side of atlas.

- SECOND $\left(\mathrm{LoCO}_{2}\right)$ :

Visible only on deep side of muscle, and separable only on its medial border; runs anteromediad more diagonally than other parts.

ORIGIN: Fleshy and tendinous from lateral parts of ventral sides of cervical centra 3,4 , and possibly 5 , medial to origins of first division.

INSERTION: Fleshy on atlas medial to first division, and deep to and fused with third division.

- THIRD $\left(\mathrm{LoCO}_{3}\right)$ :

Largest, covering second division ana having its tendons of origin and insertion with their pinnate fibers visible on its surface, especially medially.

ORIGIN: Broadly tendinous from ventral sides of centra of cervical 6 and thoracics 1-2, adjacent to midline. Some superficial fibers also arise from deep side of longus capitis.

INSERTION: Tendinous and fleshy on ventral sides of cervicals $1-5$, adjacent to midline.

REMARKS: Similar in overall pattern but different in minor details from both $T$. manatus described by Murie. As with the scalenus and longus capitis, there is clearly considerable individual variation in this muscle's vertebral attachments.

\section{MUSCLES OF THE THORAX}

MM. LEVATORES COSTARUM (LeC: Fig. 25) : (Murie, 1872: 144.)

ORIGIN : Fleshy from posterior sides of transverse processes of thoracics 1-14. Thin and distinguishable from intercostales externi only by their vertebral attachments.

INSERTION: Fleshy on anterior sides of ribs 2-15, proximal to and continuous with insertions of intercostales externi. 


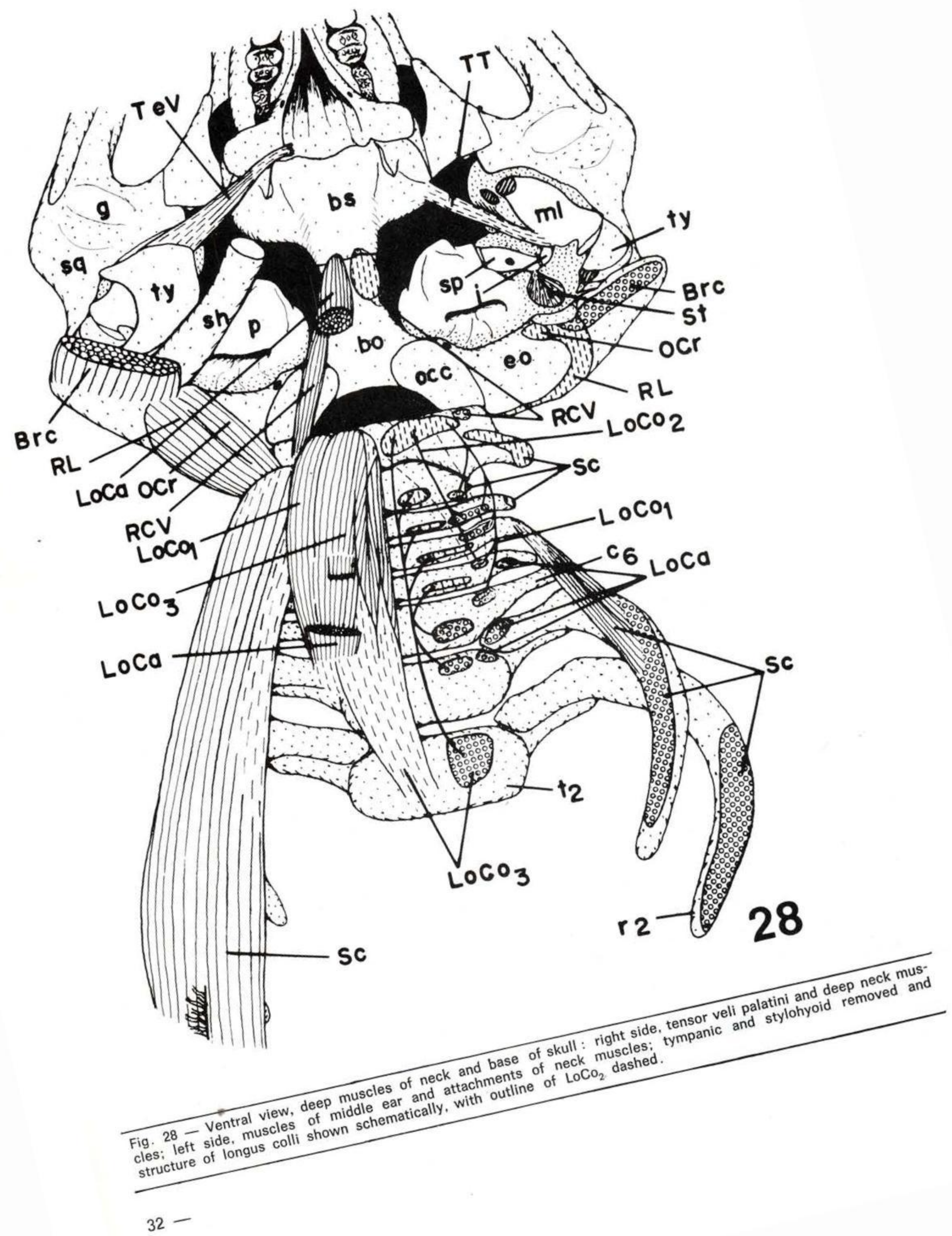


MM. INTERCOSTALES EXTERNI (IntE: Figs. 1, 2, 6, 24-27, 29):

(Murie, 1872: 151, fig. 9.)

ORIGIN : Fleshy from posterior sides of ribs 1-14.

INSERTION: Fibers pass posteroventrad to fleshy insertions on anterior sides of ribs 2-15. In INPA-PB 8 the intercostales externi were absent from distal parts of last six intercostal spaces; in INPA-PB 14, from last four spaces.

MM. INTERCOSTALES INTERNI (Intl: Figs. 26, 29) :

(Murie, 1872: 151, fig. 44; Murie, 1880: pl. 8: fig. 2.)

ORIGIN: Thin sheets deep to intercostal retia and nerves, with fleshy origins from anterior sides of ribs 2-14. In after part of thorax, intercostales interni have fewer and fewer fibers proximally and are well developed only near distal ends of ribs. A fan-shaped bundle converging on tip of rib 13 (proximal to bundle of obliquus abdominis internus joining ribs 13 and 14) arises broadly from anterior side of rib 14 up to, and actually overlapping externally, the intercostalis externus. A similar bundle between ribs 12 and 13 does not quite reach intercostalis externus. More anteriorly, these bundles at ends of ribs are continuous with dorsal parts of intercostales interni rather than separated from them by vacant spaces, as between ribs 12-13 and 13-14.

INSERTION: Fibers pass anteroventrad to insert by thin aponeuroses on posterior edges of ribs 1-13, from just distal to tubercula down to near tips of ribs. Steeper in inclination than intercostales externi.

MM : INTERCARTILAGINEI EXTERNI (Inc: Figs. 6, 27, 29):

ORIGIN: Fleshy from posterior sides of costal cartilages 1-3.

INSERTION: Fleshy on tips of ribs $2-4$ and anterior sides of lateral parts of costal cartilages 2-3.

REMARKS: Apparently separate from intercostales interni; continuous with and inseparable from intercostales externi, despite their anteroventrad direction. At distal ends of ribs, intercostales externi become more horizontal and finally incline anteroventrad as they pass into intercartilaginei. Illustrated by Murie (1880: pl. 8: fig. 2), though not distinguished by him from the intercostales.

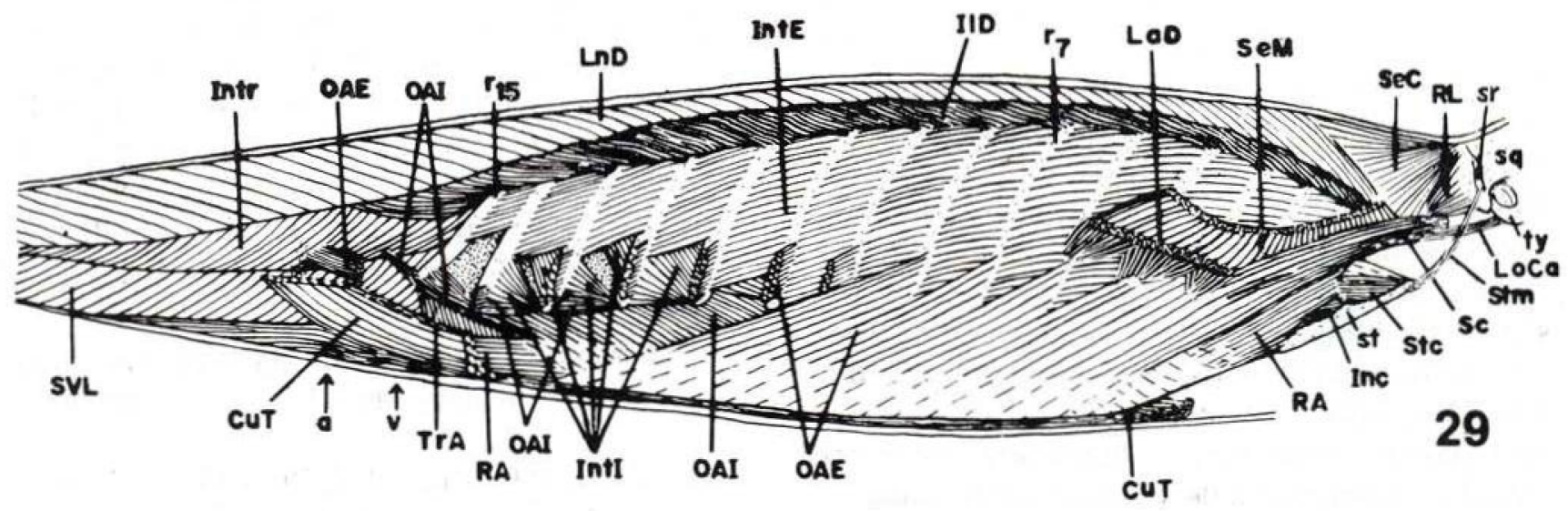

Fig. 29 - Right lateral view of neck, trunk, and base of tail; pectoral girdle and limb, most of cutaneus truncl, and posterior parts of latissimus dorsi ond obliquus abdominis externus removed. 
M. STERNOCOSTALIS (Stc: Figs. 6, 26, 27, 29) :

(Murie, 1880: pl. 8: fig. 2: "sterno-costal".)

ORIGIN: Tendinous and fleshy from entire anterior edge of first costal cartilage, just to joint with rib.

INSERTION: Tendinous on lateral edge of manubrium.

REMARKS: Fairly fleshy sheet with suggestion of a longitudinal division. Essentially an anterior continuation of intercartilaginei. A shining aponeurosis arises from whole distal half of anterior edge of first rib (up to and including distinct bulge on anterior edge of rib) and passes to edge of manubrium, closing space between latter and rib. It is crossed by another set of aponeurotic fibers running anteroposteriorly. In INPA-PB 14 these aponeuroses were deep to and separable from the sternocostalis, but in INPA-PB 9 they lay in about the same plane. The latter condition more resembled that seen in Dugong (Domning, 1977a).

DIAPHRAGM :

(Murie, 1872: 154, figs. 30, 37, 44, 49, 50.)

Nearly horizontal in position. Muscular portion attaches to medial sides of ribs about one-eighth or less of way from their distal ends. Attachment to rib 15 is only indirect, by a tendinous extension of fibers; thin tendinous sheet also continues posterior edge of diaphragm aft onto suface of sacrococcygei ventrales lateralis and medialis, which it crosses on sharply oblique line from distal end of rib 14 to centrum of thoracic 15. Muscular fibers run strongly anteromediad posteriorly, more nearly transversely anteriorly. Diaphragm is approximately half tendinous, the tendinousmuscular boundary lying more medially at posterior end, where it crosses dorsal side of kidney near latter's center; forward of fourth rib, this boundary turns anterolaterad. Diaphragm is closely adherent to pericardium, but only the latter attaches directly to sternum and costal cartilages. Pulmonary ligament attaches to dorsal side of diaphragm close to midline to as far back as thoracic vertebra 12 . The diaphragm had the highest myoglobin content of all muscles of $T$. inunguis examined by Blessing (1972) .

\section{MUSCLES OF THE ABDOMEN}

M. CUTANEUS TRUNCI (CuT: Figs. 1-4, $6,26,29,36,37,41$ ) :

(Stannius, 1845: 34-35; Krauss, 1872: 263, 268: ?"Muskel X", in part; Murie, 1872: 163-164, figs. 8-10, 30, 46, 49, 50: "panniculus carnosus, P.c" in part, including "P.c*", "P.c**", and "P.c**"; Petit, 1925: 251-253, figs. 55, 56, 58: "pannicule charnu"; Saban, 1975: 233-234, 241-244, figs. 1, 3: "panniculus carnosus".)

ORIGIN: First, from side of face as continuation of platysma pars jugularis, crossing dorsal part of scapula. This portion is joined on its superficial ventral side just abaft axilla by slip (Murie's "P.C" ) arising from superficial fascia at elbow. Further abaft axilla, lateral part of cutaneus is joined medially by sheet (Murie's "P.C"*") arising from surface of pectoralis major, adjacent to midline and slightly overlapped by sphincter colli profundus pars auris.

INSERTION: Passes aft from above attachments as single broad sheet of parallel fibers extending from ventral midline (where it lies adjacent to its fellow) out to (initially) beyond tips of ribs; abaft flipper, lateral edge of muscle descends posteroventrad across flank. Muscle is continuous dorsally with superficial aponeurosis of trunk, but its fibers do not pass into latter. Deep side of muscle tightly adherent to obliquus abdominis externus. Passing around genital opening and anus, cutaneus sheet divides at about level of anus; lateral portion turns posterolaterad and ends in superficial aponeurosis on side of base of tail, while medial half continues posteromediad and turns inward to fleshy and tendinous insertion with its fellow on ventral ends of chevrons 3-8. In female, a few fibers (Murie's "levator ani"; 1872: 162, fig. 50) pass posteromediad into connective tissue behind vulva.

REMARKS: Murie notes an insertion of the caudal portion only onto the sixth chevron.

\section{OBLIQUUS ABDOMINIS EXTERNUS}

(OAE: Figs, 2, 3, 6, 26, 29, 37):

(Murie, 1872: 155, figs. 8, 9, 30, 44, 50.)

ORIGIN: Fleshy from posterolateral sides of ribs 3-14 very near their distal ends, and by 
fleshy slip (continuous with scalenus, q.v.) from rib 2. Not conspicuously pinnate.

INSERTION: By aponeurosis onto outer surface of rectus abdominis, passing posteromediad, and fleshy onto surface of intertransversarius back to level of postthoracic 5 .

REMARKS: Murie found origins "from the third to the last rib inclusive".

\section{OBLIQUUS ABDOMINIS INTERNUS}

(OAl: Figs. 2, 26, 29):

(Murie, 1872: 155, fig. 9.)

ORIGIN: Fleshy from tips of ribs 4-15. A few fibers arise from surface of intertransversarius abaft tip of rib 15. Fibers from each rib form flat bundle more or less distinct from adjacent ones.

INSERTION: Fibers run forward at acute angle to rectus abdominis and pass into thin aponeurosis forming part of its sheath. Separate, robust bundles of fibers join tips of ribs 14 and 15,13 and 14 , and 12 and 13 , and more anteriorly merge with intercostales interni; whether these be not instead considered part of the latter is somewhat arbitrary.

REMARKS: Murie found origins "from the third to the last rib".

M. TRANSVERSUS ABDOMINIS (TrA: Fig. 29) :

(Stannius, 1845: 34; Murie, 1872: 154, fig. 9: "transversalis"; Petit, 1925: 253-254, fig. 56:

"transverse de l'abdomen".)

oRIGIN: Fleshy from medial sides of ribs 3-15 near their distal ends (distal to diaphragm).

INSERTION: By aponeurosis (lying against wall of abdominal cavity) to ventral midline via deep sheath of rectus abdominis. Extends back to level of rib 15; remaining space between transversus abdominis and sacrococcygeus ventralis spanned by thin tendinous sheet.

M. RECTUS ABDOMINIS (RA: Figs. 3, 26, $27,29,36,37,40,41,44$ ):

(Murie, 1872: 155-156, figs. 9, 37, 46, 50; Petit, 1925: 252-253, figs. 55-57: "grands drotts de l'abdomen"; Freund, 1930: 437, figs. 6, 8.)

ORIGIN: Tendinous and fleshy from posterolateral edge of sternum and posterior edge of costal cartilage 3 ; also by tendinous and fleshy slip from tip of rib 1 (external to costal cartilages). In INPA-PB 9, also had fleshy origins from middle parts of costal cartilages 1-2.

INSERTION: Runs aft parallel to its fellow, the penis in the male lying in space between and below them. Tapers abruptly to fleshy insertion on lateral side of ischium. Superficial side of rectus sheath tightly adherent to cutaneus trunci.

\section{MUSCLES OF THE TAIL.}

The $\mathrm{mm}$. sacrococcygei dorsales lateralis et medialis (Murie's "levatores caudae externus et internus", 1872: 144, figs. 8,39 ) are continuous with and inseparable from the longissimus and transversospinalis systems, respectively, and have already been described with the epaxial muscles.

\section{INTERTRANSVERSARIUS COCCYGEUS (Intr: Figs. 1-3, 29, 37):}

(Stannius, 1845: 35-36: "transversarii"; Stannius, 1849: 22; Murie, 1872: 146-147, figs. 8, 39, 44, 50: "lumbo-caudalis"; Slijper, 1946: 74: "intertransversarius caudae dorsalis".)

A thick fusiform bundle extending prominently along side of tail, overlapped anterodorsally by posterior end of iliocostalis dorsi, which adheres closely to its surface. Attachment of cutaneus aponeurosis is continuous along dorsal edges of iliocostalis and intertransversarius, back to about level of sixth postthoracic vertebra.

ORIGIN: Anteriorly, arises deep to rib 15, in partial fusion with sacrococcygei ventrales lateralis and medialis at rear of abdominal cavity. Has strong lateral tendinous attachment to posteromedial side of rib 15 at level of attachment of iliocostalis to that rib; also tendinous and fleshy origins from tips of transverse processes of postthoracics 1-8. Strong aponeurosis sheaths medial side of muscle; fibers also arise from this aponeurosis between and ventral to transverse processes of vertebrae, which lie along dorsal edge of muscle. Some fibers also arise from superficial aponeurosis of trunk, which covers muscle laterally. 
INSERTION: Fibers pass posteroventrad onto both sides of internal tendon lying in ventral part of muscle. This tendinous sheet emerges from ventral edge of muscle onto its medial side at about level of postthoracic 6 , merges with aponeurosis lying on muscle's medial side, and passes posterodorsad onto ventral sides of transverse processes of postthoracics 8 to 13 or 14 . Fibers diminish in volume posteriorly, and tendon finally becomes exposed on ventrolateral side of muscle as well, at level of postthoracic 9; fibers peter out entirely just forward of postthoracic 11 .

REMARKS: Murie reported this muscle as beginning at the "sacral or first true caudal vertebra" ( $=$ postthoracic 4 ?) and extending "along the next eight processes", abaft which it terminated in a tendon on the surface of the sacrococcygeus ventralis lateralis; this seems likely to be in part erroneous. I cannot explain the remarkable and rather cryptic statement of Stannius $(1845,1849)$ that both a "transversarius inferior" and a "transversarius superior" are present, the latter passing forward across all the ribs, outboard of (and so evidently distinct from) the "sacrolumbalis" (= iliocostalis), and attaching to each of the ribs!

\section{SACROCOCCYGEUS VENTRALIS LATER-}

ALIS (SVL: Figs. 2, 3, 29, 36, 37):

(Murie, 1872: 145-146, figs. 8, 9, 37, 39, 44, 50:

"sacro-coccygeus".)

ORIGIN : Fleshy from ventral sides of transverse processes of third to about twentieth postthoracics. Fused with sacrococcygeus ventralis medialis anterior to postthoracic 6 , and continuous here with fibers inserting on superficial side of aponeurosis of latter muscle (q.v.).

INSERTION: By aponeurosis onto tips of third and following chevrons and ventral sides of caudal vertebrae nearly to tip of tail; fleshy part of muscle distinct to about postthoracic 20 or 21 . Insertion covered anteriorly by cutaneus trunci.

M. SAGROCOCCYGEUS VENTRALIS MEDIALIS (SVM: Fig. 3):

(Murie, 1872: 146-147, figs. 9, 37, 39, 44: "infracoccygeus" + "quadratus lumborum".)
ORIGIN: Fleshy from ventral sides of centra and transverse processes of postthoracics 1-19. and from sides of all chevrons; tendinous from medial side of rib 15 and posterior edges of ventral sides of thoracics 14 (near midline) and 15 (more laterally), passing ventrally to intercostal retia.

INSERTLON : By superficial aponeurosis (deep to and separable from aponeurosis of sacrococcygeus ventralis lateralis, and with more longitudinally-aligned fibers) onto tips of third and following chevrons. Development of cordlike tendons is less evident in the hypaxial aponeuroses than in the epaxial. Forward of postthoracic 7 , muscle fibers also insert on superficial side of this aponeurosis, medially to rest of muscle's fleshy part visible in ventral view, and reaching almost to midline; these are inseparable from fibers of sacrococcygeus ventralis lateralis.

REMARKS: Murie's "quadratus lumborum" (1872: 146-147, fig. 44), extending from the last two thoracic vertebrae and last rib to the first chevron bone, corresponds to the anteromost part of the muscle described here. Stannius (1845: 35), however, found the hypaxial muscles in $T$. inunguis extending forward only "to the region of the last lumbar vertebra". His remaining comments on the hypaxial muscles are not sufficiently clear to be of use.

As in $T$. manatus, a deep posterior hypaxial muscle ("flexor haemalis") such as I described for Dugong (Domning, 1977a) is absent.

\section{MUSCLES OF THE SHOULDER}

M. TRAPEZIUS (Trp: Figs. 1, 2, 4, 5, 32): (Murie, 1872: 156, fig. 8.)

ORIGIN : Anteriorly, by aponeurosis from dorsal midline beginning $1-2 \mathrm{~cm}$ abaft nuchal line; fibers reach almost to midline. Posteriorly, by aponeurosis arising from thoracic aponeurosis a few centimeters from vertebral border of scapular cartilage. Posterolateromost fibers roughly parallel with scapular spine; posterolateral border of muscle, which is tendinous, lies approximately on an extension of direction of scapular spine. 
INSERTION: Tendinous on whole scapular spine. Posterior fibers all converge on tuber spinae; deep side of muscle here marked by radiating shining fasciae. Faint tendinous band also visible on superficial side, intersecting spine at tuber spinae at angle of about $30^{\circ}$. Posterior to tuber spinae, trapezius not attached to scapula, surfaces of scapular muscles, or tendinous band crossing surface of infraspinatus (see discussion of latter under m. deltoideus) .

M. RHOMBOIDEUS (Rh: Figs. 6, 24, 30, $33,35)$ :

(Murie, 1872: 156, figs. 8, 13.)

ORIGIN: In INPA-PB 8, formed one continuous unit, but in INPA-PB 14 arose as two narrow, distinct flat bands: Anterior band, by flat tendon from dorsal midline, superficial to posterior part of splenius; fibers began about $1 \mathrm{~cm}$ from midline. Posterior band slightly broader, arising from aponeurosis on surface of semispinalis capitis, posteroventral to anterior band.

INSERTION: Anterior band had fleshy insertion on middle and posterior part of scapular cartilage and (very slightly) vertebral border of scapula, and, more anteriorly, by a few fibers onto medial surface of serratus magnus. Posterior band inserted on medial side of scapula and cartilage and vertebral edge of cartilage near posterior vertebral angle.

M. SERRATUS MAGNUS (SeM: Figs. 6, 25, $29,30,32,33,35$ ):

(Murie, 1872: 153, figs. 13, 29.)

ORIGIN: Anteriorly, tendinous (inseparable from scalenus) from dorsal parts of transverse processes of cervicals 3-5 and possibly 6 (aprarently from cervicals 2-5 In INPA-PB 8 , and in INPA-PB 6 extending to atlas together with scalenus); fleshy and tendinous from proximal half of posterior edge of rib 1 (separated from scalenus by cleft through which emerges a vascular rete); and fleshy from middle of rib 2. Posteriorly, tendinous from distal parts of ribs 3-6, and fleshy from surfaces of intercostales externi between ribs; from rib 2 back, again inseparable from dorsal edge of scalenus.
These anterior and posterior parts are not separable at either origin or insertion.

INSERTION: Fleshy onto medial sides of scapula and cartilage, anteriorly reaching vertebral border but posteriorly lying ventral to rhomboideus insertion; a few fibers insert on lateral side of posterior corner of cartilage. Fibers of posterior half of muscle converge on posterior corner of scapula; intersection of ventral edge of insertion with posterior edge of scapula marked by "teres major protuberance" on posterior edge.

M. CEPHALOHUMERALIS (Ch: Figs. 1, 3, $5,24,26,35)$ :

(Murie, 1872: 156-157, figs. 13, 29: "cephalohumeral".)

ORIGIN: Tendinous from superficial aponeuroses covering side of squamosal between zygomatic process and sigmoid ridge; no direct attachment to bone.

INSERTION: Descends as long narrow band, its posteromedial side in contact with front of shoulder, to insert tendinously on lateral part of anterior surface of brachiocephalicus at level of head of humerus. These two muscles are separated about $2 \mathrm{~cm}$ above their junction by a large nerve passing perpendicular to their fibers.

REMARKS: In $T$. manatus, Murie found this muscle with "a fleshy origin from the entire length of the prominent ridge of the outer occipital" and "inserted on the inner and anterior side of the neck of the humerus by a very short, but strong, tendon" - rather at variance with the conditions in $T$. inunguis; but see below.

M. BRACHIOCEPHALICUS (BrC: Figs. 6 , $11-13,24,26,28,33,35)$ :

(Murie, 1872: 157, fig. 13: "levator claviculae (?)".)

ORIGIN: Fleshy from posteroventral side of squamosal, along line from ventral end of sigmoid ridge (just lateral to insertion of sternomastoideus) to posteroventral edge of squamosal and onto exoccipital just behind stylohyoid attachment; some fibers may arise from proximal end of stylohyoid. 
INSERTION: Descends front of shoulder with cephalohumeralis and inserts tendinously on surfaces of brachialis and deltoideus at latter's insertion; also has fleshy and tendinous insertion on humerus mediodistal and adjacent to insertion of deltoideus.

REMARKS: Murie found the cephalohumeralis rather than the brachiocephalicus to insert directly on the humerus in $T$. manatus; the same is true of Dugong (Domning, 1977a). Possibly this varies intraspecifically; in any case it seems to make no functional difference which muscle the distal segment is considered to belong to. It is the tendinous insertion of one of these muscles onto the surface of the other that Murie suggested to be a vestige of a clavicle. Although the names "cephalohumeralis" and "brachiocephalicus" are often used synonymously, I employ them both here for convenience in referring to the two proximal branches.

M. LATISSIMUS DORSI (LaD: Figs. 1, 5, $6,24,26,29,30,33,35)$ :

(Stannius, 1849: 14, 16; Murie, 1872: 153, figs. 8, 9, 13; Bahrdt, 1933: 237, fig. 22.)

ORIGIN: Dorsal part arises by aponeurosis from flank just abaft scapula, deep to and dorsally overlapped by posterion trapezius. Ventral part arises from flank in fairly distinct flat bundles by tendons from ribs 4-6 near their distal ends. Dorsal and ventral parts separated for most of muscle's length by longitudinal cleft through which emerge nerves and a vascular rete.

INSERTION: Passes forward as broad triangular sheet, dorsally covering posterior angle of scapula and crossing origin of teres major, and unites with latter on lower half of its lateral surface, separated from it on deep side by small vascular rete. Ventral part joins dorsal at about same level, and both insert together with teres major (q.v.) by strong tendon onto humerus.

REMARKS: Stannius found the latissimus arising from ribs 3-7 in $T$. inunguis; Murie, from ribs $4-8$ in $T$. manatus. In contrast to all manatees, the latissimus of Dugong arises from the cutaneus trunci and inserts with the pectoralis minor rather than the teres major (Domning, 1977a).
M. PECTORALIS MAJOR (PMa: Figs. 3, 5, $6,26,33,35)$ :

(Murie, 1872: 157-158, figs. 9, 13, 30; Bahrdt, 1933: 238, fig. 22.)

ORIGIN : Fleshy from ventral side of manubrium, lateral to sphincter colli profundus pars auris, from origin of sternomastoideus to posterior end of xiphoid process, and from surface of rectus abdominis sheath just abaft sternum.

INSERTION: By very strong tendon into rugose pit about $1 / 3$ of way from distal end of medial side of humerus, distal and slightly anterior to insertion of teres major and latissimus dorsi, and anterior to coracobrachialis insertion. Posterior part of pectoralis major slightly separable distally; it narrows and becomes tendinous before joining rest of tendon of insertion. From distal edge of this tendon, a sheet of fascia extends onto antebrachial fascia on medial side of anterior edge of forearm, but has no attachment to radius as in $T$. manatus.

REMARKS: An aponeurotic extension to the radius, similar to that described for $T$. manatus by Murie, has been observed in Dugong (Domning, 1977a) but not in $T$. senegalensis. $T$. inunguis also lacks the partly separable deep division of the pectoralis major found in Dugong.

M. PECTORALIS MINOR (PMi: Figs. 3, 6 , 26, 27, 33, 35) :

(Murie, 1872: 157, figs. 9, 13, 30.)

ORIGIN: Fleshy from tendinous covering of ventral surface of sternocostalis; from first costal cartilage at its junction with sternum; from medial parts of cartilages 2 and 3 ; and from surface of rectus abdominis abaft cartilage 3, at about level of after end of origin of pectoralis major.

INSERTION: Fleshy and tendinous onto humerus at mediodistal corner of supraspinatus insertion, just anterolateral to bicipital groove, which is crossed by pectoralis minor. Tendon of pinnate insertion exposed on deep side of muscle.

REMARKS: Murie states that in $T$. manatus it inserts "into the head of the humerus". In Dugong it shares a common insertion with the 
latissimus dorsi and part of the pectoralis major (Domning, 1977a). Note that in using the terms "pectoralis major" and "pectoralis minor" I am merely following Murie's designation of the muscles according to relative size and position, and not taking a position on their homologies with the pectoral muscles of other mammals.

\section{MUSCLES OF THE FORELIMB}

Note that Bahrdt (1933: fig. 24) provides schematic cross-sectional illustrations of the forelimb of $T$. senegalensis.

M. DELTOIDEUS (D: Figs. i, 5, 24, 26, 30, 32, 33) :

(Murie, 1872: 158, fig. 8; Bahrdt, 1933: 237, fig. 22.)

ORIGIN: Fleshy from scapular spine, from tip of acromion to tuber spinae.

INSERTION: By strong tendon onto deltoid with origin of brachialis, and covered by tendon of insertion of brachiocephalicus. A longitudinal tendinous band is visible on middle of niuscle's deep surface, extending several centimeters proximad from insertion. An aponeurosis extends from muscie's distal edge over lateral surfaces of brachialis and lateral head of triceps and towards forearm.

REMARKS: A flat tendinous band crosses the surface of the infraspinatus (attached to latter only by loose fascia) from the rugosity at the anterior end of the teres major origin to the edge of the deltoideus near the tuber spinae; no fibers take origin from this, however. (See also discussion under Origin of teres major.) This band is also present in Dugong (Domning, 1977a), but there it serves for parts of both the origin of the deltoideus and the insertion of the trapezius. In the manatee, with its elongated acromion process, it appears as if the scapular attachments of these two muscles have slid anteroventrad along the spine, leaving the tendinous band vacant hehind. It has not been recorded in $T$. manatus or $T$. senegalensis. In $T$. manatus, Murie found the deltoideus bifurcating at its insertion and embracing the brachialis (1872: 160; not embracing the "biceps" as he inadvertently states on p. 158), with its posterior branch continuing "towards the elbow"; the latter branch evidently corresponds to the aponeurosis described above. Bahrdt did not observe these conditions in $T$. senegalensis, nor did 1 in Dugong.

M. SUPRASPINATUS (Sup: Figs. 24, 30, 32, 33, 35) :

(Murie, 1872: 156, fig. 13.)

ORIGIN: Fleshy from supraspinous fossa of scapula and anterior side of spine except its ventralmost part, and nearly to tip of acromion process. Dorsal to spine, there is no clear division between supraspinatus and infraspinatus. Some supraspinatus fibers arise from anterior edge and anteromost part of medial side of scapula.

INSERTION: Passes distad as thick convexforward sheet enclosing coracoid process on latter's lateral, anterior, and medial sides. Has broad sheetlike internal tendon and several deeper internal tendinous bundles, which insert with muscle fibers onto tuberosity anterior to head of humerus. Supraspinatus and infraspinatus separable near insertions, former slightly overlapping anterior edge of latter.

M. INFRASPINATUS (Inf: Figs. 1, 5, 24, 30, 32):

(Murie, 1872: 156, fig. 8.)

ORIGIN: Fleshy from infraspinous fossa of scapula and dorsal part of posterior side of spine. A few superficial fibers arise from underside of deltoideus near its origin. Some of the most anterior bundles have separate fleshy origin from posterior side of acromion process beneath and close to deltoideus.

INSERTION : Pinnate on tendon exposed along lower distal part of muscle, and on deeper, more dorsal flat internal tendon parallel to the first. Both tendons visible on deep side near their insertion, with a few muscle fibers, onto tuberosity lateral to head of humerus.

M. SUBSCAPULARIS (Su: Figs. 33, 35): (Murie, 1872: 156, figs. 9, 13.)

ORIGIN: Fleshy from most of medial side of scapula above narrowest part of neck, except 

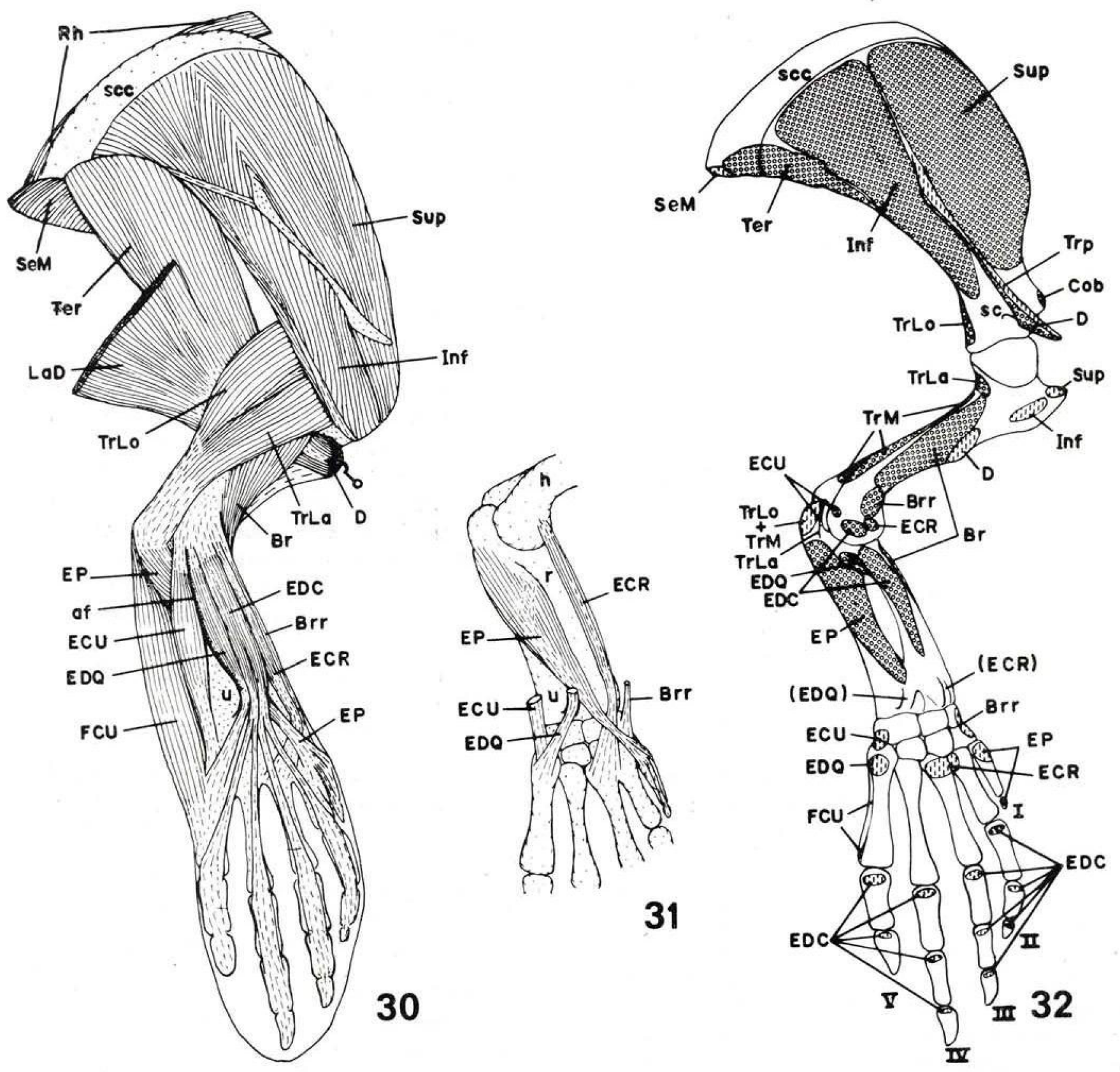

Figs. 30-32 - Lateral views of right forelimb: 30, muscles of shoulder and forelimb: trapezlus, most of deltoldeus, and antebrachial fascia removed; posterior line of attachment of latter shown (af); 31 , detail of extensor pollicis and extensor carpi radialis: 32, bones of pectoral girdle and limb, showing muscle attachments and grooves for tendons of extensor muscles (abbreviations in parentheses). 


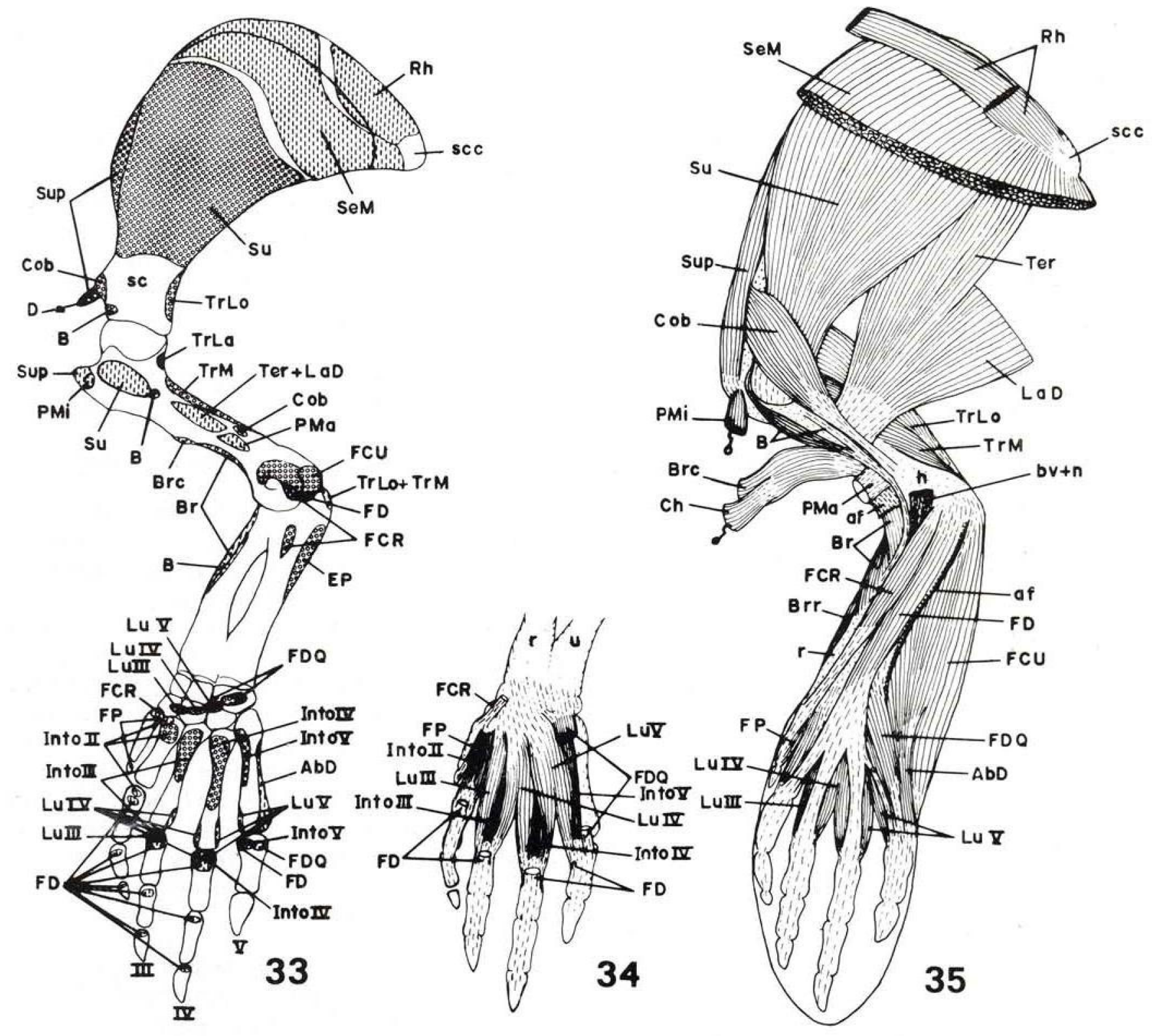

Figs. 33-35 - Medial views of right forelimb: 33 , bones of pectoral girdle and limb, showing muscle attachments: 34 , muscles of palm; 35 , muscles of shoulder and forelimb, with most of brachial rete and nerves (bv\&n) and antebrachial fascia (af) removed; posterior line of attachment of latter shown. 
vertebral border and posterior angle (where serratus magnus inserts) and anteromost edge (where part of supraspinatus arises), and from posterior edge just distal to teres major origin.

INSERTION: Fleshy and tendinous on lesser (medial) tuberosity of humerus.

M. TERES MAJOR (Ter: Figs. 1, 5, 24, 30, $32,33,35)$ :

(Stannius, 1849: 14; Murie, 1872: 156, figs. 8, 13; Bahrdt, 1933: 237, fig. 22.)

ORIGIN: Fleshy from lateral sides of posterodorsal corner of scapula and posterior edge of scapular cartilage, bounded anteriorly by origin of infraspinatus and attachment of tendinous band crossing latter's surface (see under deltoideus). and posteriorly by "teres major protuberance" and posterior edge of scapula. In INPA-PB 8, attachment of abovementioned tendinous band on both left and right sides formed an extremely prominent, anterolaterally-pointing knoblike process, to the medial side of whose bare summit the tendinous band to the tuber spinae was attached. Teres major took fleshy origin from posteroventral side of this process as well as from posterior corner of scapula and scapular cartilage. Subscapularis also had fleshy attachment to distalmost part of posteroventral side of process, and infraspinatus had fleshy attachment to anterior side of process. Other shoulder muscles were normal. I have observed a similar development in the skeleton of only one other $T$. inunguis (INPAPB 103), an approximately 2.6-meter male from the Rio Juma, Amazonas, in which a wide flat process arches up from the anterodistal edge of the teres origin and points toward the tuber spinae.

INSERTION: Fuses with latissimus dorsi (q.v.) and inserts with it by very strong tendon into rugose pit on middle of medial side of humerus. Pectoralis major inserts into a more distal and smaller portion of this pit, separated from proximal portion by a low diagonal ridge running posterodistad across the pit. absent.
M. CORACOBRACHIALIS (Cob: Figs. 32, 33, 35) :

(Murie, 1872: 159-160, fig. 13: "biceps, B"; Murie, 1880: 32; Bahrdt, 1933: 237, figs. 22, 24: "biceps, innere Strang".)

ORIGIN: Tendinous and fleshy from medial side of coracoid process of scapula, though tendon covers anterior side of process as well. Fibers arise pinnately from small tendinous area on deep side of muscle.

INSERTION: As it crosses insertion of subscapularis, muscle widens, forming single broad fusiform belly inserting pinnately on narrow tendon to posteromedial side of humerus, attaching about $2 / 3$ of way to distal end of bone and just posterior to distal part of pectoralis major insertion.

M. BICEPS BRACHII (B: Figs. 33, 35) :

(Murie, 1872: 159-160, fig. 13: "biceps, B2"; Murie, 1880: 32, pl. 8: fig. 3; Bahrdt, 1933: 237, figs. 22, 24: "biceps, äussere Strang".)

ORIGIN: By very long, slender tendon from anterior and anteromedial rim of glenoid cavity (distal to origin of coracobrachialis), which passes through bicipital groove of humerus. Has single, very slender belly. Just at distal end of belly, tendon of insertion is joined by a separate tendon of origin, which arises from humerus immediately posterodistal to subscapularis insertion and crosses tendon of insertion of teres and latissimus, deep to coracobrachialis and posterior and parallel to belly of biceps. This posterior tendon has no muscular fibers. Its point of origin is marked by a distinct rugosity in adults.

INSERTTON: By single tendon (lying along, and distally adherent to, posteromedial edge of brachialis) onto medial edge of proximal end of radius. Insertion covered by anterior edge of antebrachial vascular rete and a large nerve.

REMARKS: This curious structure of the biceps has not been observed in any other sirenian. The posterior accessory tendon appears to serve as a "check ligament" to restrict extension of the elbow. It should be emphasized that a small (relative to dugongids) 
but very well-developed bicipital groove is characteristic of $T$. inunguis, in sharp contrast to $T$. senegalensis, where it is but faintly marked, and $T$. manatus, where it is totally absent. The biceps in the latter species is fused proximally with the coracobrachialis, which led Murie to consider them a single double-bellied muscle. The manner of origin of the biceps in $T$. senegalensis is unknown.

M. TRICEPS BRACHII:

(Murie, 1872: 158, fig. 13: "triceps"; Murie, 1880: pl. 8: fig 3; Bahrdt, 1933: 236-237, figs. 22, 24: "triceps".)

Has three divisions, an anconeus, as in other sirenians, being absent.

- LONG HEAD (TrLo: Figs. 5, 30, 32, $33,35)$ :

(Murie, 1872: 158, fig. 13: "scapular head; T"; Bahrdt, 1933: 236: "third" head.)

ORIGIN: Fleshy from triangular area on posterior side of distal end of scapula.

INSERTION: Passes into broad thin tendon (continuous with, and overlapping medial part of, tendon of lateral head) in distal third of humerus, and inserts on posterolateral side and (by much stronger and thicker part of tendon) tip of olecranon. At distal end of muscle's fleshy part, some lateral fibers anastomose with lateral head and insert via its tendon.

- LATERAL HEAD (TrLa: Figs. 5, 30, 32, 33) :

(Murie, 1872: 158, fig. 13: "middle head; $T^{2}$ ";

Bahrdt, 1933: 236: "second" head.)

ORIGIN: Fleshy and tendinous from distal side of neck of humerus.

INSERTION: Extends distad as flat sheet covering medial head, and separated from it by 3 large nerves passing diagonally laterodistad and by some small blood vessels. Has thin tendon along lateral edge. Passes into broad thin tendon in distal quarter of humerus, and inserts on posterolateral side of olecranon; also extends still further distad as fascia covering proximal end of extensor carpi ulnaris and rest of antebrachium.

- MEDIAL HEAD (TrM: Figs. 32, 33, 35): Murie, 1872: 158, fig. 13: "short head; $\mathrm{T}^{3}$ "; Bahrdt, 1933: 236: "first" head.)
ORIGIN : Fleshy from posterior side of humerus, from neck to olecranon fossa, medial to and separated slightly from area of origin of brachialis; bounded medially by insertions of teres, latissimus, and coracobrachialis. Muscle thicker on medial edge, thins laterad; fibers trend mediodistad.

INSERTION: Fleshy and tendinous on lateral, anterior, and medial sides of olecranon; a set of superficial tendinous bands join at apex of olecranon to form tendon of insertion which adheres to deep side of tendon of lateral head.

M. BRACHIALIS (Br: Figs. 30, 32, 33, 35): (Murie, 1872: 160, figs. 8, 13: "brachialis ananticus"; Murie, 1880: 32, pl. 8: fig. 3; Bahrdt, 1933: 237 , figs. 22,24 .)

ORIGIN: Fleshy from lateral side, and distal half of anterior side, of humerus, from neck to ectepicondyle; bounded posteromedially by medial head of triceps and anteromedially by deltoideus, brachiocephalicus, and pectoralis major attachments.

INSERTION: Fleshy on proximal half of anterior side of radius; also pinnate on superficial shining fascia at distal end of muscle's medial side, continuous with antebrachial fascia over flexor carpi radialis. Muscle partly divisible on medial side near insertion.

REMARKS: In $T$. senegalensis, Bahrdt found the brachialis arising by a "flat and wide tendon" from the capsular ligament of the head of the humerus; it inserted fleshily on the distal end of the radius, in contrast to $T$. manatus and $T$. inunguis. In Dugong there are separate proximal and distal insertions, the latter tendinous (Domning, 1977a).

M. BRACHIORADIALIS (Brr: Figs. 30-32, 35) :

(Murie, 1872: 158, fig. 8: "supinator longus"; Bahrdt, 1933: 238; figs. 22, 23, 24.)

ORIGIN: Fleshy and tendinous from anteroproximal side of ectepicondyle of humerus, at laterodistal end of origin of brachialis. Medial side of muscle closely adherent proximally, but not fused, to brachialis. 
INSERTION: By single tendon (exposed on distal half of muscle's anterior side) through anteromost groove on anterolateral side of distal end of radius, onto anterior sides of carpals; seems to stop just short of metacarpal I.

\section{EXTENSOR CARPI RADIALIS (ECR :}

Figs. 30-32):

(Murie, 1872: 158-159, fig. 8: "extensores carpi radiales longior and brevior"; Bahrdt, 1933: 238-239; figs. 22, 23, 24: "extensor radialis longus und brevis".)

ORIGIN : Fleshy and tendinous from ectepicondyle of humerus, distal to origin of brachioradia!is. Has shining fascia on deep side near origin.

INSERTION: Onto tendon (exposed down middle of muscle for about $3 / 4$ of its length) which passes through middle groove of radius, under tendon of extensor pollicis, and onto posterior half of proximal end of metacarpal II and proximal end of metacarpal III.

REMARKS: Tendon of insertion lies parallel to that of brachioradialis rather than being obliquely crossed by it and extensor pollicis. as stated by Murie (1872: 159). He probably meant that extensor pollicis crosses brachioradialis and extensor carpi radialis. Latter, together with extensor digitorum communis and extensor digiti quinti, is completely covered by antebrachial fascia.

\section{EXTENSOR DIGITORUM COMMUNIS}

(EDC: Figs. 30-32):

(Murie, 1872: 159, fig. 8: "extensor communis digitorum"; Bahrdt, 1933: 239, figs. 22, 24.)

ORIGIN: Tendinous from ectepicondyle of humerus behind extensor carpi radialis, and from joint capsule; fleshy and tendinous from posterolateral side of radius down to just beyond distal end of interosseous space.

INSERTION: Complexly pinnate on two principal (anterior and posterior) tendons, which are exposed distally on surface of muscle. These pass through anterior groove of ulna; eacb divides in two, the anterior pair inserting on digits $\mathrm{II}$ and III, the posterior on IV and V. Insertions are on proximal ends of phalanges. In INPA-PB 8 and 9 there was also a very thin tendon inserting on proximal end of phalanx of digit I; on left side of no. 8 another thin tendon from anterior edge of extensor digitorum communis tendon inserted partly onto tendon of extensor pollicis, with a deeper branch onto the radial carpal. A carpal branch was also well developed in INPA-PB 6.

REMARKS: Murie mentions an origin from the ulna in $T$. manatus not observed in the other species. Bahrdt mentions only the epicondylar attachment in $T$. senegalensis.

M. EXTENSOR DIGITI QUINTI (EDO: FIgs. 30-32):

(Murie, 1872: 159, fig. 8: "extensor minimi digiti"; Bahrdt, 1933: 239, figs. 22, 24.)

ORIGIN: Fleshy and tendinous from distal side of capsule of elbow joint, from lateral side of junction of radius and ulna, and from posterolateral side of proximal end of radius, where it is closely adherent on its proximal deep side to extensor digitorum communis. No fibers reach proximad of joint capsule; only possible attachment to humerus is via superficial antebrachial fascia.

INSERTION: By tendon (exposed laterally on muscle's distal end) through posterior groove of ulna, turning sharply aft to insert on proximal end of metacarpal $\mathrm{V}$; does not reach phalanges.

REMARKS: In $T$. senegalensis, Bahrdt found the origin on the ectepicondyle of the humerus. In both other manatee species, as well as Dugong (Domning, 1977a), the tendon of insertion extends to the proximal phalanx of digit $V$. Antebrachial fascia is attached to posterolateral side of ulna along posterior edge of extensor digiti quinti and deep to extensor carpi ulnaris .

\section{EXTENSOR CARPI ULNARIS (ECU :}

Figs. 30-32) :

(Murie, 1872: 159, fig. 8; Bahrdt, 1933: 239-240, figs. 22, 24.)

ORIGIN: From surface of flat tendon from posterodistal corner of ectepicondyle of humerus; tendon also has weaker posterior branch from side of olecranon beneath lateral and medial heads of triceps. 
INSERTION: Passes distad as strong, very prominent band, overlapping posterior side of extensor digiti quinti proximally and not covered by antebrachial fascia. Fibers insert on deep side of broad tendon which passes beneath that of extensor digiti quinti and onto lateral sides of ulnar carpal (cuneiformpisiform) and adjacent proximal end of metacarpal V.

REMARKS: Murie and Bahrdt fail to mention an origin from the olecranon, though the latter's fig. 22 does show a bifurcate tendon. Murie found the insertions on the unciform (hamate), magnum (capitate), and metacarpal V. In stating that "its fibres... mingle with those of the carpi radialis", Murie probably meant instead "with those of the flexor carpi ulnaris."

\section{EXTENSOR POLLICIS (BREVIS ET} LONGUS) (EP: Figs. 30-33):

(Murie, 1872: 159, fig. 8: "extensores primi and secundi internodii pollicis"; Bahrdt, 1933: 240, fig. 23.)

ORIGIN : Fleshy from entire lateral and anterolateral sides of ulna except its bare posterodistal area, including lateral side of olecranon distal to insertion of medial head of triceps; from interosseous membrane; and even from proximal parts of posterior edge and medial side of ulna. In INPA-PB 8, some fibers also arose from posterolateral side of proximal end of radius. Proximal end of muscle crossed by shining tendinous bands passing posterodistad.

INSERTION: Pinnate onto superficial shining fascia passing into flat tendon, which runs anterodistad through posterior groove of radius, beneath extensor digitorum communis tendons and across tendons of extensor carpi radialis and brachioradialis. Tendon partly divided at insertion, anterior part going to anterior and posterior part to lateral side of proximal end of metacarpal I; an extension of posterior part passes as thin tendon to phalanx of digit I (not observed in INPA-PB 9).

REMARKS: Murie, but not Bahrdt, found a partial division of this muscle into two parts; neither observed an extension to the phalanx. The part which Murie found arising from the interosseous space (his "secundi internodii pollicis"; probably $=$ extensor pollicis brevis) most likely corresponds to the separate muscle of the dugong which I called the ?abductor pollicis longus (Domning, 1977a), and which has not been otherwise observed in Trichechus.

I did not find a pronator teres, nor any radial insertion of the flexor carpi radialis that might represent it. However, Bahrdt (1933: 240 , figs. 22, 24) found it well developed in T. senegalensis, and Murie (1872: 160, fig. 13: "pronator radii teres") observed it in one $T$. manatus, though in a second (1880: $32, \mathrm{pl} .8$ : fig. 3) it was fused with the flexor carpi radialis, which had a radial insertion. It was distinct though vestigial in one Dugong (Domning, 1977a) .

\section{FLEXOR CARPI RADIALIS (FCR: Figs.} 33-35):

(Murie, 1872: 160, fig. 13; Murie, 1880: 32, pl. 8: fig. 3; Bahrdt, 1933: 240, figs. 22, 24.)

ORIGIN: Tendinous from anterodistal side of entepicondyle of humerus. Proximal end sheathed in shining fascia on both sides; deep fascia has small attachment to medial side of proximal end of ulna.

INSERTION: Complexly pinnate, ending in wide, strong tendon on proximal ends of metacarpals I and II, and (in INPA-PB 9) distal carpal. Distal part of muscle covered in shinıng fascia.

REMARKS: Has no radial origin (as in Dugong) or insertion (as in $T$. manatus). In Dugong it attaches to the distal carpal as well as to the metacarpals (Domning, 1977a), while in $T$. senegalensis Bahrdt mentions only insertions on both proximal and distal anterior carpals.

\section{PALMARIS LONGUS :}

(Murie, 1872: 160-161, figs. 13, 14; probably not equivalent to "palmaris longus" of Murie, 1880: 32-33, pl. 8: fig. 3, or Bahrdt, 1933: 240, figs 22,24 .)

ORIGIN: From entepicondyle of humerus together with flexor carpi radialis, by thin aponeurosis covering posterior surface of latter's proximal end. More distally visible as thin fusiform belly between flexor carpi radialis and flexor digitorum. 
INSERTION: By thin supefricial tendon onto surface of palmar muscles in fork between flexor digitorum tendons to digits II and III.

REMARKS: Observed only on left side of INPA-PB 9. Murie (1872) reported a distinct "palmaris longus" lying abaft and "enwrapping" the tlexor carpi ulnaris, and inserting on metacarpal $\mathrm{V}$, in one $T$. manatus. In a second specimen (1880) he thought the palmaris longus might be represented by what he alternatively termed the "flexor brevis minimi digiti"; this I regard as an ?abductor digiti quinti. The name "palmaris longus" may be applicable to both Murie's first case and the present one, as this muscle is highly variable, for example in humans. When not distinct in sirenians, it is perhaps simplest to regard it as absent rather than fused with the flexor carpi ulnaris, as past authors (including Domning, 1977a) have assumed.

\section{FLEXOR DIGITORUM (SUPERFICIALIS ET PROFUNDUS) (FD: Figs. 33-35):}

(Murie, 1872: 160, fig. 13: "flexor sublimis" + "flexor profundus"; Murie, 1880: 32-33, pl. 8: figs. 3, 4; Bahrdt, 1933: 240, figs. 22, 24: "flexor sublimis + profundus", )

ORIGIN : Tendinous from distal side of entepicondyle of humerus; proximal end sheathed in shining fascia on both sides. Muscle overlapped and enclosed posteriorly by flexor carpi ulnaris. In the right flipper only of INPA-PB 9, some fibers arose from antebrachial fascia between flexor digitorum and flexor carpi ulnaris, and a partly separable deep anterior part had fleshy origin from anterodistal end of ulna. In INPA-PB 117, a small bundle of fibers arose from posteromedial side of distal end of radius and joined anterior side of muscle's distal end.

INSERTION: Pinnate on strong internal tendon which divides over proximal parts of metacarpals; branches to digits II-IV insert on proximal ends of phalanges. A small, thin, flat tendon diverges at a sharp angle from posterior edge of tendon to digit IV, about $1 / 3$ of way distad along metacarpal IV, and inserts at distal end of metacarpal $V$ onto tendinous covering of proximal phalangeal joint. In INPA-
PB 9 this small tendon ended on surface of posterior palmar muscles. On right side of INPA-PB 8, a deep anterior part of muscle sent tendon to digit II, while the stronger tendons to III and IV were from a superficial part; on left side these parts were not separable and the tendon to II was very thin, like that to V. In INPA-PB 117 the muscle was likewise more clearly subdivided than in INPA-PB 14; it was nearly divisible on posteromedial side at about middle of forearm, the smaller posterior part sending a powerful tendon to digit IV and a very tiny one to anterior side of $\mathrm{V}$. Anterior part sent two small parallel branches to II and a strong pair of parallel tendons (one divided tendon) to III, and also sent a few fibers onto tendon to IV at level of proximal parts of metacarpals. In INPA-PB 6 the tendon to $V$ was absent.

REMARKS: In $T$. manatus Murie found tendons only to digits II-IV, but Bahrdt shows a well-developed branch to $\mathrm{V}$ in $T$. senegalensis. In all manatees the division into superficial and deep portions seems to be slight and variable at best, in contrast to the well-marked division observed in Dugong (Domning, 1977a).

A flexor pollicis longus was not observed; Murie (1872: 160; 1880: 32-33) and Bahrdt (1933: fig. 24) took it to be fused with the flexor digitorum. It is also absent in Dugong (Domning, 1977a).

M. FLEXOR CARPI ULNARIS (FCU: Figs. $5,30,32,33,35$ ) :

(Murie, 1872: 160-161, figs. 13, 14; Murie, 1880: 32-33, pl. 8: fig. 3; Bahrdt, 1933: 240, figs, 22, 24.)

ORIGIN: Tendinous and fleshy from posteromedial protuberance of entepicondyle of humerus. Has prominent tendon exposed along proximal third of its anteromedial edge, which proximally overlaps flexor digitorum.

INSERTION: Broadens rapldly into thick triangular sheet, inserting by aponeurosis at its base along whole posterolateral edge of metacarpal. V, but chiefly by tendon at distal end of metacarpal. In INPA-PB 6, however, was confined to proximal part of metacarpal, as shown by Murie (1872) . 
REMARKS: No trace of a division observed that might correspond to a palmaris longus as described by Murie (1872) (see discussion of latter muscle, above).

\section{?M. ABDUCTOR DIGITI QUINTI (AbD :}

Figs. 33, 35) :

(Murie, 1872: 161: "flexor brevis minimi digiti"; figs. 13, 14: "abductor minimi digiti"; Murie, 1880: 34, pl. 8: fig. 3: "palmaris longus" and/or "flexor brevis minimi digiti".)

ORIGIN : Fleshy from distal part of antebrachial fascia, continuous proximally with flexor carpi ulnaris, but more distally forming separate bundle running parallel to metacarpal $V$ across medial side of insertion of flexor carpi ulnaris. At this bundle's posteroproximal edge, where the two muscles begin to separate, a tendinous patch is exposed on medial surface of abductor digiti quinti.

INSERTION: Fleshy and tendinous along whole posterior edge of metacarpal $\mathrm{V}$ (medial to flexor carpi ulnaris), and on posteromedial side of its distal end.

REMARKS: The labelling of this and the following muscle in Murie's (1872) illustrations conflicts with his text and later work (1880); here, as in the case of Dugong (Domning, 1977a), I have named them in accordance with the relative positions of similar muscles in the human hand, though the homologies are of course uncertain. Their forms in $T$. manatus and $T$. inunguis show no significant differences.

?M. FLEXOR DIGITI QUINTI BREVIS (FDQ:

Figs. 33-35):

(Murie, 1872: 161: "abductor minimi digiti"; figs. 13, 14: "flexor brevis minimi digiti"; Murie, 1880: 34, pl. 8: figs. 3, 4: "abductor minimi digiti".)

ORIGIN: Tendinous from fascia covering ulnar carpal. Anterior part of tendon of origin is a short flat band extending anteroproximad beneath flexor digitorum.

INSERTION: By short, flat tendon onto palmar side of proximal end of proximal phalanx $\mathrm{V}$, posterior to lumbricalis $\mathrm{V}$.

REMARKS: See foregoing muscle. In one T. manatus, Murie (1880: 34, pl. 8: figs. 3,4 ) observed a separate muscle arising from the ulna or ulnar carpal and inserting on the radial edge of digit $\mathrm{V}$, which he tentatively termed an "opponens minimi digiti". This was absent in my specimens, or fused with the undivided flexor digiti quinti brevis.

?M. FLEXOR POLLICIS BREVIS (FP: Figs. 33-35) :

(Murie, 1880: 34, pl. 8: figs. 3, 4: "flexor brevis pollicis or... adductor pollicis".)

ORIGIN: Tendinous from fascia over junction of proximal ends of metacarpals I and II; forms very small bundle anterior and similar to interosseus II.

INSERTION: Tendinous on posteromedial side of phalanx 1 .

REMARKS: Absent in Murie's first specimen of $T$. manatus (1872), and in Dugong (Domning, 1977a) .

MM. LUMBRICALES (Lu III-V: Figs. 33-35) : (Murie, 1872: 161, figs. 13, 14, 15: "superficial interossei"; Murie, 1880: 33, pl. 8: figs. 3, 4: "superficial interossei" + "lumbricalis".)

In three distinct divisions, attaching to digits III-V:

- III (Lu III) :

ORIGIN: Tendinous and fleshy from wrist fascia over proximal end of metacarpal II.

INSERTION: Tendinous on anterior side of proximal end of proximal phalanx III. In INPAPB 8, some fibers inserted on distal part of metacarpal II. Forms narrowly exposed but thick muscle mass between metacarpals II and III.

- IV (Lu IV) :

ORIGIN: Fleshy and tendinous from fascia over proximal end of metacarpal III.

INSERTION: Fills crevice between metacarpals III and IV; divides distally, part going to posterior sides of distal end of metacarpal and proximal end of proximal phalanx of digit III, and part to anterior sides of metacarpal and phalanx IV; insertions tendinous and fleshy on metacarpals and tendinous on phalanges.

\section{- V (Lu V):}

ORIGIN: Fleshy and tendinous from fascia over proximal end of metacarpal IV; overlapped posteriorly by flexor digiti quinti brevis.

INSERTION: Fleshy belly (largest of the three lumbricales) divides distally between 
metacarpals IV and V, its parts inserting fleshily and tendinously on posterior and anterior sides of distal ends of metacarpals IV and $V$, respectively, possibly with tendinous extensions to proximal ends of proximal phalanges IV and V. In INPA-PB 117, some fibers inserted on thin tendon of flexor digitorum to proximal phalanx $\mathrm{V}$.

REMARKS: See under interossei, below.

MM. INTEROSSEI (Into II-V: Figs. 33, 34): (Murie, 1872: 161, fig. 15: "deep" or "dorsal interossei"; Murie, 1880: 33-34, pl. 8: fig. 4.)

I divide these into four groups, according to the digits (II-V) on which they insert. All have some shining fascia on their surfaces, and lie deep to the lumbricales.

\section{- II (Into II):}

ORIGIN: In three fairly separable bundles: anteromost from posterior side of proximal end of metacarpal I (fleshy); others tendinous from base and fleshy from palmar side of proximal end of metacarpal II.

INSERTION: Tendinous on metacarpo-phalangea! joint II.

\section{- III (Into III):}

ORIGIN: Tendinous from base and fleshy from proximal half of palmar side of metacarpal III. Has anterior and posterior divisions and is large but very narrowly exposed between lumbricales III and IV.

INSERTION: Tendinous on metacarpo-phalangeal joint III.

\section{- IV (Into IV):}

ORIGIN: Tendinous from base and fleshy from proximal half or more of palmar side of metacarpal IV. Has well-separated anterior and posterior divisions, narrowly exposed between lumbricales IV and V.

INSERTION: Tendinous on metacarpo-phalangeal joint IV.

\section{- V (Into V):}

ORIGIN: Tendinous and fleshy from anterior side of base, and fleshy from proximal half of anteromedial side, of metacarpal $\mathrm{V}$; undivided.
INSERTION: Tendinous on anteromedial side of metacarpo-phalangeal joint $\mathrm{V}$.

REMARKS: The arrangement of lumbricales described above is almost identical to that of the "superficial interossei" found in T. manatus by Murie (1880), and I regard these as equivalent despite Murie's finding, in the same specimen, of "a single distinct lumbrical muscle" from the wrist-fascia to the fourth digit; this I consider merely a chance subdivision of the adjacent "superficial interossei". Substantially the same pattern was also encountered in Dugong (Domning, 1977a), except that there the lumbricales did not attach to the ulnar sides of the digits as they seem to predominantly do in Trichechus. Murie's first $T$. manatus (1872) showed an even more complex arrangement of "superficial interossei" than the second (1880). The "deep interossei" of Murie likewise correspond in general to the "interossei" I have described in $T$. inunguis and Dugong; however, the detailed attachments of all these muscles differ slightly in each sirenian, and there seems to be little hope of homologizing their individual parts with muscles in the human hand. Thus I have adopted the simple convention of regarding the superficial palmar muscles of sirenians as as lumbricales and the deeper layer as interossei, recognizing a considerable degree of individual variation in both.

\section{MUSCLES OF THE PELVIC AND GENITAL REGION (FEMALE)}

M. ISCHIOCOCCYGEUS (Isc: Figs. 3, 36, $37,40,41,44)$ :

(Krauss. 1872: 263, 268: ?"Muskel X", in part; Murie, 1872: 161-162, figs. 9, 46, 50: "ischio-" and/or "ilio-coccygeus"?; Freund, 1930: 438, figs. $6,7,8$ : "ischiococcygeus"?)

ORIGIN: Fleshy from posteroventral part of lateral side of ischium, posteroventral to insertion of rectus abdominis.

INSERTION: Fibers pass aft and immediately blend with those of overlying cutaneus trunci passing posteromediad to chevron bones.

REMARKS: This corresponds to the ischiococcygeus of Dugong (Domning, 1977a). It is unclear from Murie's description of the "ischio- 

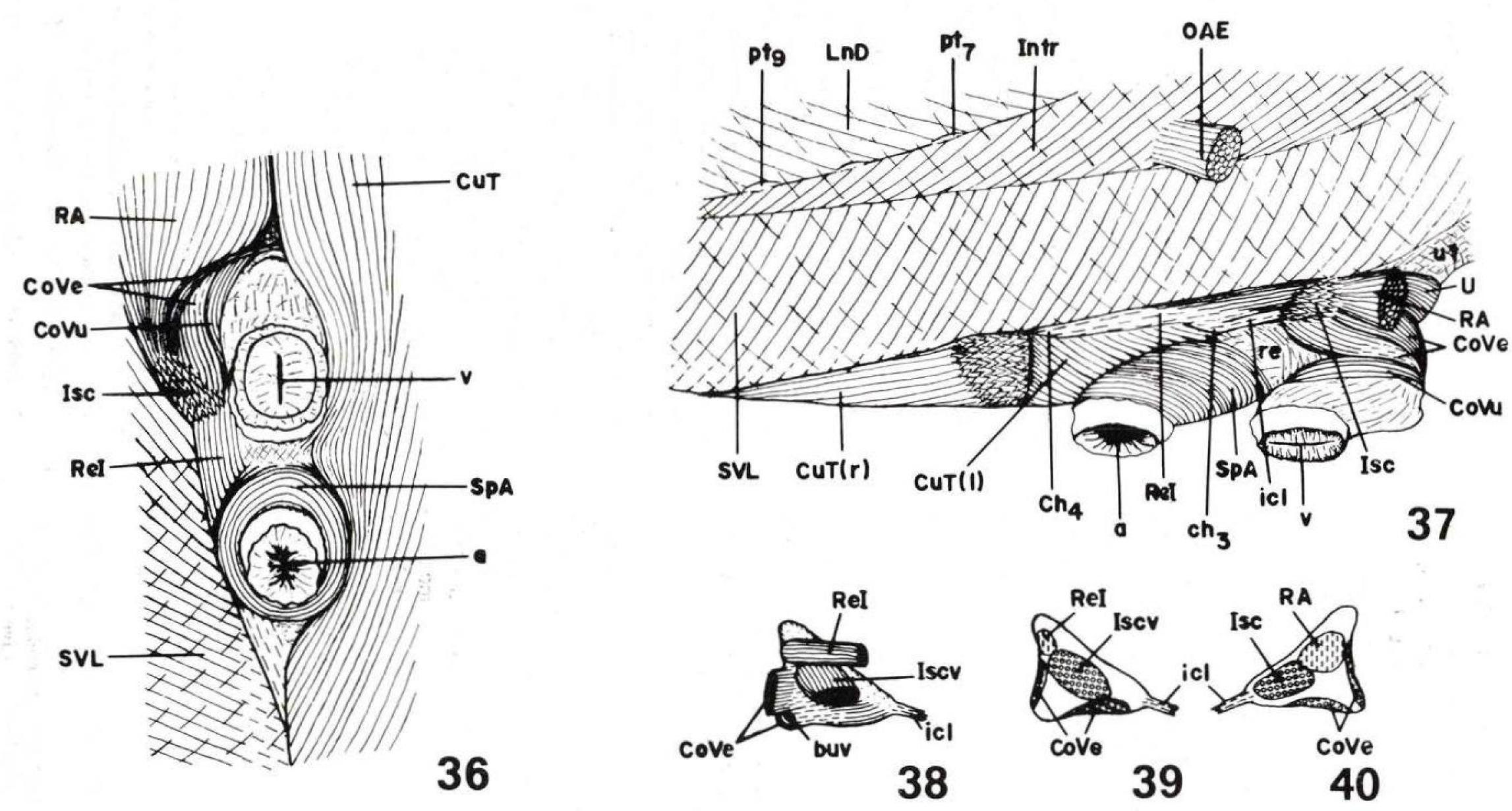

Figs. 36-40 - Female pelvic and genital muscles : 36 , ventral view of perineal region, cutaneus trunci removed on right side: 37 , right lateral view of perineal
region and ventrolateral part of base of tail, most of right cutaneus trunci and abdominal muscles removed, posteromost part of right cutaneus trunci and part $\vec{b}$ of left visible; 38, medial view of right ischium and attached muscles; 39 , medial view of right ischium, showing muscle attachments; 40, lateral view of same. 
or ... ilio-coccygeus" in $T$. manatus, and Freund's of the "ischiococcygeus" in $T$. inunguis, whether they were observing this muscle or the retractor ischii $(q \cdot v \cdot)$.

Murie's "levator ani" (1872: 162, fig. 50) is here described as part of the cutaneus trunci $(q \cdot v \cdot)$.

\section{RETRACTOR ISCHII (Rel: Figs. 3, 36-39,} 41-43):

(Stannius, 1845: 9; Stannius, 1849: 35: "retractor ischii" or "ischio-caudalis"; Krauss, 1872: 278: ?"levator recti"; Murie, 1872: 161-162, figs. 9, 46, 50: "ischio-" and/or "ilio-coccygeus"?; Freund, 1930: 438, figs. 6, 7, 8: "ischiococcygeus"?)

ORIGIN: Tendinous and fleshy from tips of chevrons 3 and 4 .

INSERTION: Crosses sacrococcygeus ventralis lateralis as thin but distinct band and inserts fleshily on medial side of ischium, at anterior edge near dorsal corner.

REMARKS: This clearly corresponds to the "thin and weak" muscle which Stannius found arising from the chevrons of "the first two caudal vertebrae" in $T$. inunguis. (Murie, incidentally (1872: 162), misinterpreted the footnote in which Stannius makes this statement to be a quotation from Rapp (1837). As he made the same error in regard to the scalenus (1872: 152), Murie had evidently not seen Rapp's work at first hand.) This muscle also corresponds to the retractor ischii of Dugong (Domning, 1977a), where it is better developed. As noted above, it is uncertain whether the muscle of $T$. manatus which Murie (1872) took to be its equivalent was not in fact the ischiococcygeus of this description, and the same holds true for the "ischiococcygeus" of $T$. inunguis described by Freund (1930): though both seem more likely to have been the retractor ischii, as the ischiococcygeus is not distinctly separable from the cutaneus trunci.

M. CONSTRICTOR VULVAE (CoVu: Figs. 36, 37):

(Murie, 1872: 162, fig. 50: "sphincter vaginae";

Freund, 1930: 438: "constrictor vulvae"; figs. 6, 7, 8: "sphincter vaginae".)
Forms fleshy band, flattened in nearly horizontal plane, around side of vulva medial and ventral to constrictor vestibuli; fellows do not meet in midline either forward or aft. Almost touches sphincter ani posteriorly.

\section{CONSTRICTOR VESTIBULI (CoVe: Figs.} 36-40) :

(Krauss, 1872: 277-279: "ischio-cavernosus" + "muscle resembling levator penis"; Murie, 1872: 162-163, fig. 50: "erector clitoridis" + "transversus perinaei"; Freund, 1930: 438, figs. 6, 7, 8.)

ORIGIN: In two distinct and separate parts: anterodorsal part, a broad band with fleshy origin from anterior edge of ischium; posteroventral part, a similar band with fleshy origin from ventral edge and medial side of ischium.

INSERTION: Anterodorsal part: with fellow onto median raphe, anteriorly overlying posteroventral part and constrictor vulvae. Posteroventral part: into connective tissue on anterior side of vulva, together with and dorsal to constrictor vulvae. On medial side of posteroventral part, and enclosed with it in a tendinous wrapper, is the bulbus vestibuli (corpus cavernosum vestibuli of Freund, 1930). which was erroneously considered a muscular division of the constrictor vestibuli by Murie (1872) and Domning (1977a).

REMARKS: The anterodorsal part is almost certainly Murie's "transversus perinaei", even though his illustration shows the latter arising abaft rather than forward of the "erector clitoridis". The anterodorsal part also corresponds to that which I mistook for the urethralis in Dugong (Domning, 1977a).

\section{URETHRALIS (U: Fig. 37) :}

(Freund, 1930: 438-439, figs. 7, 8.)

ORIGIN: Fairly thick band arising from lateeral side of uterus, to which it is tightly adherent, and passing around anterior side of cervix and urethra, dorsal to constrictor vulvae and posterodorsal to constrictor vestibuli.

INSERTION: Meets fellow in midline anterior to urethra. 

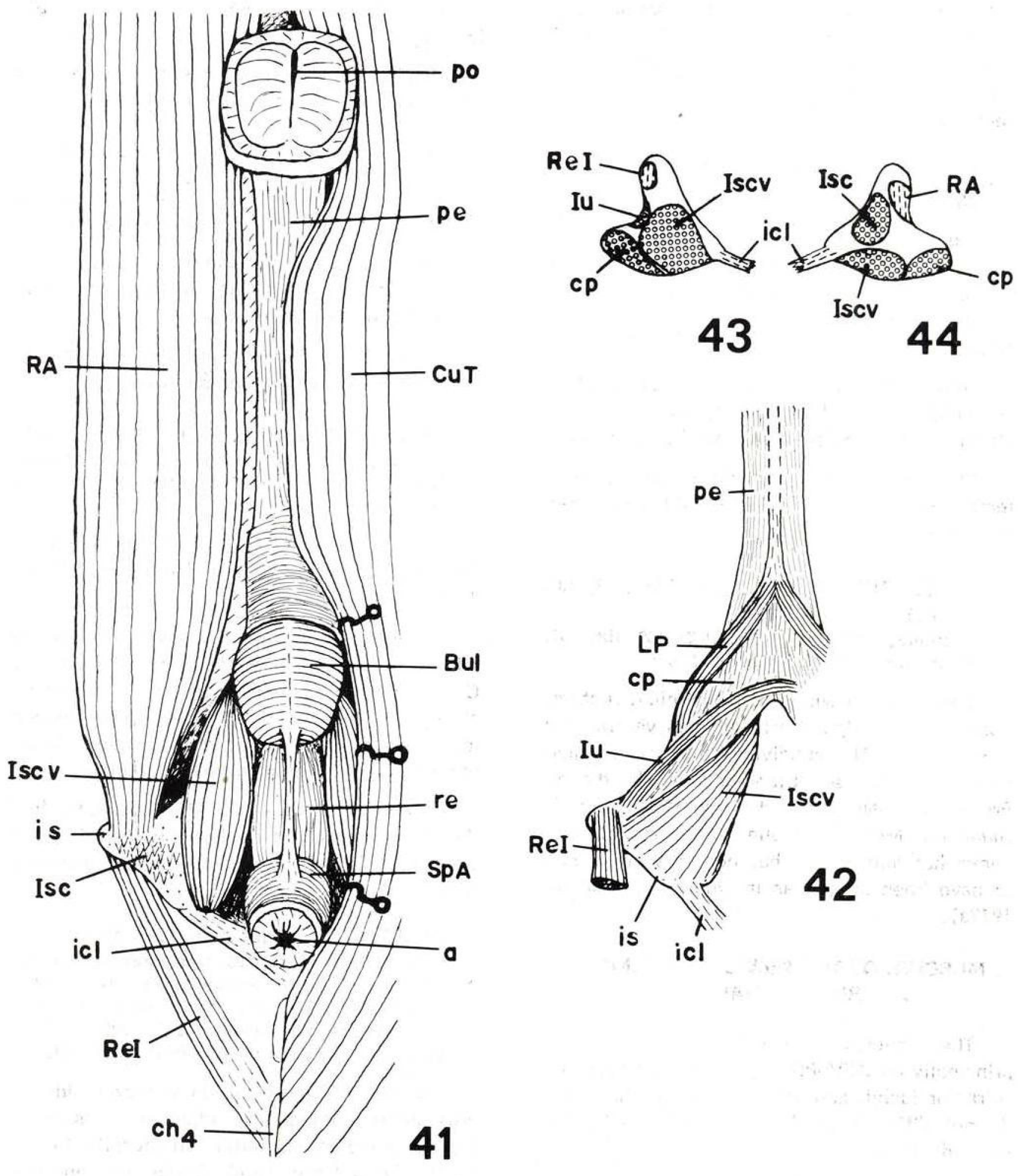

Figs. 41-44 - Male pelvic and genital muscles: 41, ventral view of perineal region, cutaneus trunci retracted on left side and removed on right; sheath of rectus abdominis removed; 42, dorsal (medial) view of left ischium and posterior part of dorsum of penis, showing attached muscles; 43, medial view of right ischium, showing attachments of muscles and crus penis (cp): 44, laterial view of same. 
REMARKS: Overlooked by Murie and myself; the muscle of Dugong which I identified as the urethralis (Domning, 1977a) was the anterodorsal part of the constrictor vestibuli.

\section{?M. ISCHIOCAVERNOSUS (IscV: Figs.} $38,39)$ :

ORIGIN: Fleshy from medial side of ischium as fairly thick mass of fibers adherent to ischium, and distinguishable ventrally from constrictor vestibuli by its more vertical fiber direction.

INSERTION: Runs ventrad and slightly posterad onto wall of uterus, dorsal to constrictor vulvae and posteroventral to urethralis.

REMARKS: Not previously observed in a female sirenian; Freund (1930: 438) considered it absent in $T$. inunguis.

M. SPHINCTER ANI (SpA: Figs. 3, 36, 37, 41):

(Stannius, 1849: 41; Murie, 1872: 162, figs. 37, 50; Freund, 1930: 439, figs. 6, 7, 8.)

Forms single wide band encircling rectum; posterodorsal edge nearly touches ventral end of chevron 3. Not subdivided into internal and external parts as Stannius found, though Freund apparently found it undivided in $T$. inunguis. Murie's account of $T$. manatus is somewhat ambiguous, but here also it seems to have been single, as in Dugong (Domning, 1977a).

\section{MUSCLES OF THE PELVIC AND GENITAL REGION (MALE)}

The following descriptions are based principally on INPA-PB 9. The ischiococcygeus, retractor ischii, and sphincter ani of the male do not differ from those of the female, described above.

M. ISCHIOCAVERNOSUS (IscV: Figs. 41-44) :

(Stannius, 1845: 9; Stannius, 1849: 41; Vrolik, 1852: 77; KFauss, 1872: 259, 260, 262; Murie, 1872: 163, fig. 37; Kaudern, 1917: 209, fig. B; Petit, 1925: 258-259, fig. 57: "ischio-caverneux (erectores penis) ${ }^{n}$.)
ORIGIN: Fleshy from medial and ventrolateral sides of ischium.

INSERTION: Fleshy on crus of penis, tightly enveloping its medial and ventral sides.

M. BULBOCAVERNOSUS (Bul: Fig. 41):

(Krauss, 1872: 263; Murie, 1872: 163, fig. 37; Kaudern, 1917: 209, fig. B; Petit, 1925: 259: "bulbo-caverneux (acceleratores urinae)".)

ORIGIr: Fleshy from side of bulbus urethrae, forming thick layer of transverse fibers enclosing it on ventral side.

INSERTION: With its fellow on raphe in midventral line of bulbus urethrae.

M. ISCHIOURETHRALIS (lu: Figs. 42, 43): (Krauss, 1872: 259, 262, 271: "wurmförmiger Muskel"; Kaudern, 1917: 210, fig. B: "retractor penis accessorius".)

ORIGIN : Fleshy from anterior edge of ischium, forming long thin band parallel and dorsal to crus penis.

INSERTION: Continuous with fellow in midline, passing around front of urethra. Connected to dorsum of penis by tendinous sheet. In INPA-PB 108 it was partly divided longitudinally, the posterior division being tendinous on its median posterior edge.

REMARKS: Petit (1925: 257) failed to find this in $T$. senegalensis, but did identify it in Dugong, calling it a "levator penis accessorius".

M. LEVATOR PENIS (LP: Fig. 42) :

(Vrolik, 1852: 77, fig. 23: "terugtrekker van den penis" = retractor penis; Krauss, 1872: 259-260, 262, 267, 268, 270, 271; Murie, 1872: 163: "retractores penis"; Kaudern, 1917: 209-210, figs. B, C, D: "retractor penis"; Petit, 1925: 257.)

ORIGIN: Fleshy from dorsolateral side of crus penis immediately adjacent to ischium, but not attaching to latter. In juvenile (INPAPB 9), formed thin band similar, and anterior and parallel to, ischiourethralis; much broader and very powerful in adult (INPA-PB 108).

INSERTION: Joins fellow over junction of crura to form single tendon which penetrates dorsum of penis and extends along dorsum into pars libera penis, inserting into corpus 
fibrosum. In adult (INPA-PB 108), insertion was partly pinnate on a complex median group of tendinous bands, of which the posterior bands were transverse (joining the two muscles) and the anterior passed anteromediad to form the large single median tendon of insertion.

REMARKS : Vrolik, Krauss, and Kaudern found this muscle to be broad, like that of the adult examined here, though the specimens of at least the first and last authors were immature. Kaudern found the tendon of insertion double and asymmetrically developed.

A retractor penis extending along the ventral side of the penis has not been reported in sirenians. I observed a distinct, stout band, mostly fibrous but apparently with some muscle fibers, extending from the anterior surface of the sphincter ani onto the ventral side of the bulbocavernosus and continuous with the latter's median raphe; this, however. probably does not deserve to be called a muscle but only represents the "central tendinous point" of the perineum.

I did not observe the "muscles rétracteurs du fourreau", apparent derivatives of the cutaneus trunci inserting on the anterior wall of the sheath near the genital opening, which were reported by Petit (1925: 257, fig. 58) .

Stannius (1849: 41) mentioned a paired muscle "arising from the processus spinosus of the second caudal vertebra" and inserting "on the base of the penis". As this is apparently not the retractor ischii, which he mentions separately on p. $35, \mathrm{I}$ am at a loss to identify it. 


\section{INTERSPECIFIC DIFFERENCES}

The muscular systems of all three species of Trichechus appear to be quite similar; more so, even, than might appear from the scanty literature. As most descriptions have been based on single specimens, it is not surprising that individual variations have at times appeared to be true interspecific differences when in reality the ranges of variation in each species are similar or identical. In other cases apparent differences have resulted from imperfectly preserved material, oversights of the anatomist, or mere differences of nomenclature. I have discussed these cases insofar as possible in the Remarks included with the foregoing descriptions; besides these, I am confident that most of the remaining "interspecific" differences which could be gleaned from these descriptions would likewise prove illusory on closer examination. Here I will comment only on the handful of differences which appear to me to constantly separate the species of manatees. Indeed, on the basis of the incomplete data available, I feel confident in affirming such differences in the cases of only two muscles, each directly associated with osteological differences which likewise consistently separate the species.

M. rectus capitis lateralis: Murie (1872, 1880) makes no mention of any difficulty encountered in separating this muscle from the semispinalis capitis in $T$. manatus, and they are certainly very distinct in Dugong (Domning, 1977a). In $T$. inunguis, therefore, I was very surprised to find them completely continuous at their cranial insertions, the fanlike rectus radiating broadly from the transverse process of the atlas rather than forming a subcylindrical, parallel-sided bundle. Correlated with this is a difference in bone structure at the insertion; in the former two species the dorsolateral border of the exoccipital (which there receives the insertion of the semispinalis capitis) is smoothly rounded and featureless (the primitive condition for sirenians), whereas in $T$. inunguis it is broadened into an overhanging rugose flange, the rugosity continuing around the lateral border of the posterior surface as far as the ventral end of the exoccipital. Virtually this whole rugose area, including the flange, is occupied by the rectus rather than the semispinalis; the latter's insertion is essentially confined to the supraoccipital. It is plain that in $T$. inunguis the rectus has been modified from its primitive function of bending the head laterally, and strengthened to serve also as an extensor of the atlantooccipital joint in conjunction with the semispinalis. The condition of these muscles in $T$. senegalensis has not been described, though there is often a slight development of an overhanging exoccipital flange in this species.

$M$. biceps brachii: As already noted, this is quite distinct from the coracobrachialis in $T$. inunguis (as well as Dugong), while in $T$. manatus the two are fused proximally and lie closely adjacent throughout their lengths. This accords with the latter species' total lack of a bicipital groove on the humerus, which lack has sometimes been mistakenly thought to characterize all manatees in contrast to dugongids. $T$. inunguis, however, has a welldeveloped bicipital groove, though a very small one by dugongid standards. Most unfortunately the proximal parts of the biceps and coracobrachialis were not preserved in Bahrdt's (1933) specimen of $T$. senegalensis, but here again the African species seems to be somewhat intermediate between the other two, as it has a faintly developed bicipital groove. The biceps of $T$. inunguis, however, is chiefly remarkable for the accessory tendon of origin, described above. Its attachment on the humerus is clearly marked in adults by a small rugosity at the distal end of the lesser tuberosity. I have not observed this rugosity in $T$. manatus, in which the accessory tendon is evidently absent. As this tendon acts to limit 
extension of the elbow, it is wortn noting that the distal limb segments are proportionately much longer in $T$. inunguis than in the other species (Bahrdt, 1933; Hatt, 1934), and accordingly encounter greater water resistance in forward strokes of the flipper, for instance while being feathered on recovery strokes.

Dugong differs from one or more of the species of Trichechus in many minor details of muscle structure and attachments which cannot be recapitulated here, but which are set forth in the present work and in my description of Dugong (Domning, 1977a). Here I will merely list the outstanding qualitative features which characterize Dugong in contrast to Trichechus: Presence of a platysma pars scapularis, musculi auriculares, a sphincter colli profundus pars palpebralis, a retractor labiorum, a separate rectus capitis dorsalis major, a flexor haemalis, separate extensores pollicis brevis et longus, and separate flexores digitorum superficialis et profundus; absence of a rectus capitis ventralis; absence of portions of the cutaneus trunci crossing the scapula and extending onto the forelimb, and passage of cutaneus fibers posterodorsad into the thoracic aponeurosis; a divided serratus magnus; attachment of the trapezius and deltoideus to the tendinous band crossing the infraspinatus; origin of the latissimus dorsi from the cutaneus trunci and its insertion together with the pectoralis minor rather than the teres major; and more anterior origin of the sacrococcygeus ventralis. The present study has also shown that some supposed differences between the genera, which I had inferred from Murie's account, do not exist; for example, the intertransversarius coccygeus and the caudal extension of the cutaneus trunci are developed to similar degrees in Trichechus and Dugong. This may yet prove to be the case with some of the above-listed features as well. 


\section{MYOLOGY OF DUGONG: CORRIGENDA}

In the course of this study several misinterpretations in my description of Dugong Domning, 1977a) have become evident. These may be briefly listed here. The lateralis nasi seems to be chiefly a depressor of the floor of the narial passage rather than a manipulator of the snout. Most of the supposed "zygomaticomandibularis" should probably be considered a superficial temporalis, and most of the "orbicularis oris" seems to correspond to the sphincter colli profundus pars oris of the present work. The supposed "aryepiglotticus" was evidently the palatopharyngeus. The "?abductor pollicis longus" seems to correspond to Murie's "extensor secundi internodii pollicis", probably equivalent to the extensor pollicis brevis. The palmaris longus is more likely absent than fused with the flexor carpi ulnaris. The supposed "urethralis" was in fact the anterodorsal part of the constrictor vestibuli, the true urethralis having been overlooked; the supposed short medial slip of the constrictor vestibuli was not a muscle but rather the bulbus vestibuli. 


\section{FUNCTIONAL ANATOMY}

Functional analysis of the manatee's entire myology is beyond the scope of this paper, which is intended as a source of morphological data for future studies. However, some observations made in the course of the dissections call for discussion going beyond pure description; this is presented below.

\section{BRISTLES OF THE UPPER LIP}

A key element in the manatee's feeding apparatus is the distinct set of large, stiff, white bristles found at the anteromedial corner of each of the lobes of the upper lip. These have been well illustrated for $T$. manatus by Vrolik (1852: fig. 5), Murie (1872: fig. 7), and Garrod (1877: pl. 28: figs. 1, 2), and for $T$. inunguis by Stannius (1845: fig. 2). As noted by Pereira (1944: 38, 40), these bristles can be withdrawn into the skin or extended at will to serve in grasping and manipulating food. The mechanism of this action has apparently never been studied and would probably repay a microscopic examination, though its main features seem sufficiently clear in gross dissection: The roots of the extrusible bristles are surrounded by muscle fibers slightly darker than those of the rest of the snout. Such fibers as were grossly visible appeared to run lateroventrad; however, external pressure applied in any direction to this region in a dead specimen causes the bristles to extrude to a startling degree. On relaxation of the pressure (or of the muscle fibers, in a live animal) the bristles are elastically retracted into their sheaths.

\section{OPENING OF THE NOSTRILS}

There has been some confusion in the literature over the mechanism of opening and closing the nostrils in sirenians; however, a clear and correct description of the process has been given by Genschow (1934: 433-435, fig. 24). The floor of the narial passage is strongly convex dorsad and lightly pigmented for about $5 \mathrm{~cm}$ inside the nostril of a juvenile animal; i.e., a distance equivalent to the foreand-aft length of the portion of the lateralis nasi arising from the side of the rostrum. This muscle's vertical fibers insert into the floor of the passage throughout this distance and act to depress it, perhaps assisted by the maxillonasolabialis. Upon relaxation of the lateralis nasi, this entire portion of the floor of the narial passage, and not just the small part visible at the nostril itself, springs back against the roof elastically, closing the passage. As in cetaceans and pinnipeds, there are no muscles which serve to close the nostrils; this is done entirely automatically by elastic tissue. and only the opening is voluntary. The latter seems to be the chief function of the lateralis nasi, contrary to my earlier supposition (Domning, 1977a) that it helped to manipulate the snout and upper lip.

\section{JAW MUSCLES}

Turnbull (1970) has provided both a simple, standardized framework for basic analysis of mammalian jaw mechanics and a large amount of data on jaw musculature of diverse mammals for comparative purposes, with which we can briefly examine some features of the manatee's jaw apparatus.

Jaw muscle weights of four juvenile $T$. inunguis are given in Table 3 . With these, and with the muscle maps of Figs. 10-15, we can estimate the static useful power (E) of any muscle or set of muscles helping to close the jaw, from Turnbull's formula

$$
E=M \times F_{L} \times F_{X} \times r
$$

where $M$ is the weight of the muscle group expressed as a percentage of the total jawclosing musculature; $F_{L}$ is a correction factor 
for the muscle's angle of pull on its effort lever arm, projected into the (parasagittal) plane of jaw closure; $F_{X}$ is a correction factor for the divergence from the vertical, in a

TABLE 3. Weights and percentages of masticatory muscles in juvenile Trichechus inunguis; left and right sides combined.

\begin{tabular}{|c|c|c|c|}
\hline Musele & $\begin{array}{l}\text { Weight } \\
\text { (g) }\end{array}$ & $\%$ & $\begin{array}{r}\% \text { (omitting } \\
\text { digostricus) }\end{array}$ \\
\hline \multicolumn{4}{|l|}{ INPA-PB 6: } \\
\hline Masseter & 9.3 & 16.6 & 17.7 \\
\hline Zygomaticomandibularis & 4.1 & 7.3 & 7.8 \\
\hline Temporalis & 27.0 & 48.1 & 51.4 \\
\hline (Superficial temporalis) & $(9.0)$ & $(16.0)$ & $(17.1)$ \\
\hline (Deep temporalis) & $(18.0)$ & $(32.1)$ & $(34.3)$ \\
\hline Pterygoideus internus & 7.7 & 13.7 & 14.7 \\
\hline Pterygoideus extenus & 4.4 & 7.8 & 8.4 \\
\hline Digastricus & 3.6 & 6.4 & $\ldots$ \\
\hline Totals & 56.1 & 99.9 & 100.0 \\
\hline \multicolumn{4}{|l|}{ INPA-PB 8: } \\
\hline Masseter & 16.3 & & \\
\hline Zygomaticomandibularis & 6.6 & & \\
\hline Temporalis & $\ldots$ & & \\
\hline Pterygoideus internus & 13.2 & & \\
\hline Pterygoideus externus & 5.2 & & \\
\hline Digastricus & 9.8 & & \\
\hline \multicolumn{4}{|l|}{ INPA-PB 9: } \\
\hline Masseter & 12.4 & 16.9 & 19.2 \\
\hline Zygomaticomandibularis & 4.0 & 5.5 & 6.2 \\
\hline Temporalis & 34.6 & 47.2 & 53.6 \\
\hline (Superficial temporalis) & (11.7) & $(16.0)$ & (18.1) \\
\hline (Deep temporalis) & $(22.9)$ & $(31.2)$ & $(35.5)$ \\
\hline Pterygoideus internus & 8.9 & 12.1 & 13.8 \\
\hline Pterygoideus externus & 4.6 & 6.3 & 7.1 \\
\hline Digastricus & 8.8 & 12.0 & $\cdots$ \\
\hline Totals & 73.3 & 100.0 & 99.9 \\
\hline \multicolumn{4}{|l|}{ INPA-PB 169: } \\
\hline Masseter & 14.7 & 17.3 & 18.5 \\
\hline Zygomaticomandibularis & 6.5 & 7.7 & 8.2 \\
\hline Temporalis & 40.4 & 47.6 & 50.9 \\
\hline (Superficial temporalis) & $(14.6)$ & $(17.2)$ & $(18.4)$ \\
\hline (Deep temporalis) & $(25.8)$ & $(30.4)$ & $(32.5)$ \\
\hline Pterygoideus internus & 12.6 & 14.8 & 15.8 \\
\hline Pterygoideus externus & 5.3 & 6.2 & 6.7 \\
\hline Digastricus $=$ & 5.4 & 6.4 & $\cdots$ \\
\hline Totals & 84.9 & 100.0 & 100.1 \\
\hline
\end{tabular}

vertical transverse plane, of the muscle's direction of pull; and $r$ is the ratio of the muscle's effort lever arm to the resistance lever arm of the system. The rationale, derivation, use, and limitations of this formula are explained in more detail by Turnbull (1970: 281-296) .

10 analyze the manatee's jaw-closing musculature, we first divide the weights of the adductor muscles in Table 3 into three groups: the weights of the temporalis $(\mathrm{Mt})$, of the masseter plus zygomaticomandibularis $(\mathrm{Mm})$, and of the pterygoideus internus (Mpti). As the pterygoideus externus of the manatee is not an adductor, it is excluded here, although Turnbull included it in his analyses of other mammals. (Only the muscle-weight data on INPA-PB 6, 9, and 169 are complete enough to use here.).

Next, maps of the attachments of each of these muscle groups are constructed in lateral view (Figs. 45-47). Functional centers of resistance to jaw-closing in the rostral and molar regions (corresponding to Turnbull's incisor-canine and premolar-molar regions, respectively) are visually estimated and lines are drawn connecting these points with the temporal condyle; these are the resistance lever arms for orthal motion around the condyle. The functional midpoints of the origin and insertion fields for each muscle group are estimated and plotted, taking into account the form, structure, and average fiber direction of the muscles. A line from the functional midpoint of each insertion field to the condyle is the muscle's effort lever arm. The angle between this and a line joining the origin and insertion midpoints is measured with a protractor, and the resulting value is compared with Turnbull's diagram (1970: fig. 41) to determine the value of the correction factor $F_{L}$ for that muscle group. The effort and resistance lever arms are measured directly from the diagrams to calculate $r$. The average directions of muscle pull are likewise projected into a transverse vertical plane (Fig. 48 ), and their divergences from the vertical measured and compared with Turnbull's diagram to obtain the values of $F_{X}$. The values of these factors for the adductor muscles are given in the top part of Table 4 . 

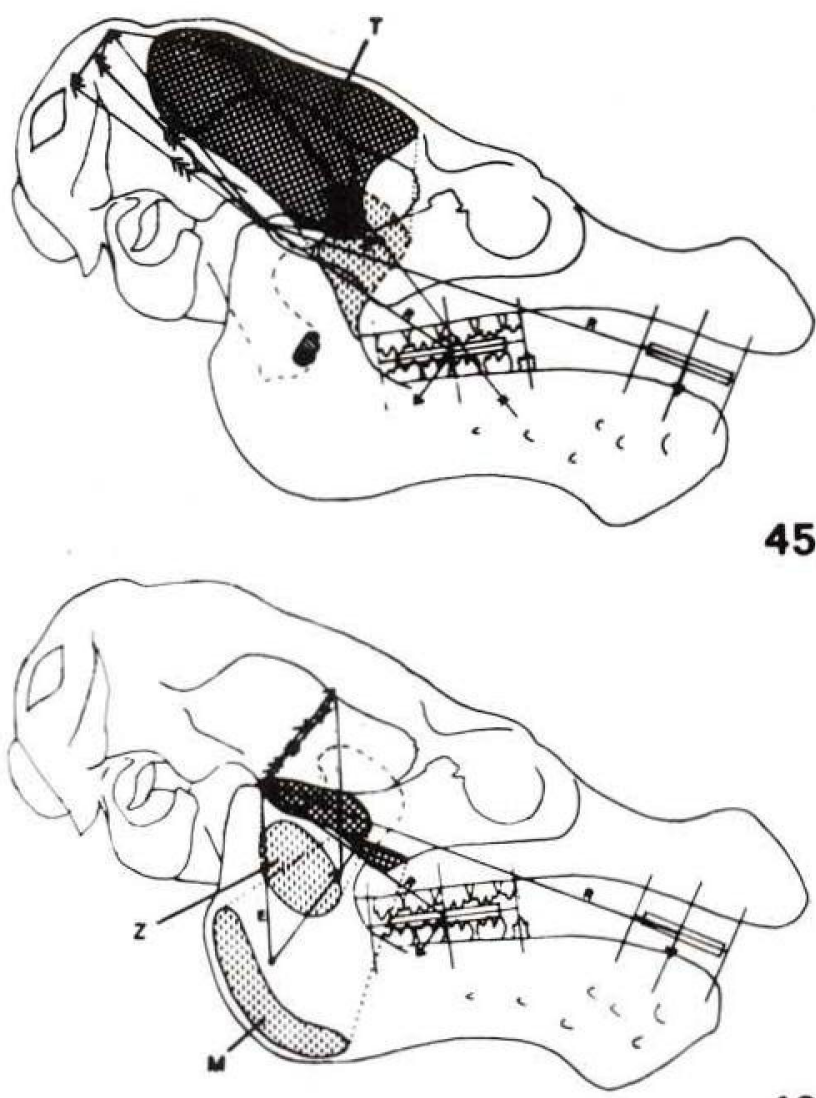

46

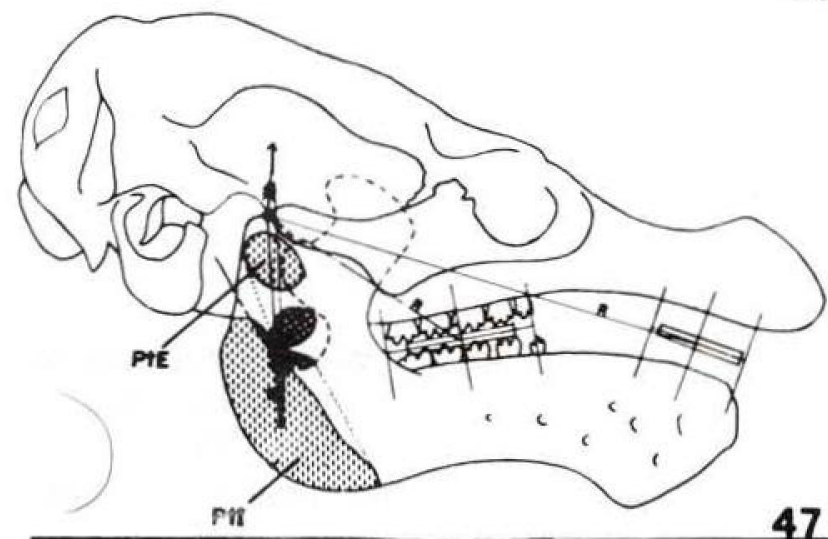

Figs. $45-47$ - Lateral views of skull and mandible of juvenile Trichechus inunguis, for analysis of jaw-closing forces (see text). Resistance lever arms (R) shown for rostral and molar regions; resistance vectors (solid-headed arrows) are proportioned to estimated useful power of each muscle group. Dots indicate estimated functional midpoints of origin and insertion fields of temporalis (Fig. 45), masseter + zygomaticomandibularis (Fig. 46), and pterygoideus internus (Fig. 47). Lines from insertion midpoints to jaw joint are effort lever arms (E). Polygons show resolution of forces at jaw joint: effort vectors (open-headed arrows) are proportional to weight of muscle group; feathered arrows mark unresolved translational force vectors. Dotted lines show outlines of muscles. Dashed lines show outlines of concealed coronoid and pterygoid processes. Cross-hatched area in Fig. 45 is pterygoid-mandibular articular surface: extension of temporalis effort vector through molar resistance field marked by $X$. Outline and attachments of pterygoideus externus shown in Fig. 47 but vector analysis of this muscles not shown. Unresolved vector of pterygoldeus internus is proportional to Mpti only, since Epti $\rightleftharpoons$ O.O.
In Table 5 are given the values of $\mathrm{M}$ for each muscle group in each specimen, as percentages of the total weight of the three groups together. These values are used with those from Table 4 to calculate the useful power $(E)$ according to the above formula; each $E$ is then converted again to a percentage of the sum of all Es. These figures express the proportion of the total jaw-closing force contributed by each muscle group, which may be greater or less than that group's share of the total adductor muscle weight. The difference, shown in the next two columns of Table 5 , results from the relative advantageousness of the group's angle of pull on its lever arm and the mechanical advantage of the lever arm itself. The results of similar calculations are shown for both the molar and the rostral resistance fields.

It must be emphasized that the estimate of useful power thus obtained applies only to orthal motion of the jaw. Especially in an animal like the manatee, this is not the only or even the most important aspect of jaw motion; so the values of $E$ in Table 5 hardly begin to reflect the true functions of the muscles. This is most obvious from the zero values obtained for Epti, indicating that the pterygoideus internus, one of the major jaw muscles, plays no significant role at all in rotating the jaw parasagittally about the condyle. Chewing in the manatee, as in most other "ungulates", appears to have a large transverse component; accordingly I have adapted Turnbull's method to analyze the muscle actions in the occlusal plane.

In Fig. 49A the average directions of muscle pull are projected into the horizontal plane, as was done for the sagittal plane in Figs. 45-47. Here, however, we are concerned with the muscles producing transverse motion, so the weights of the pterygoideus externus (Mpte) from Table 3 are included. The percentage values of $M$ are accordingly recalculated and shown in Table 6. Again using the condyle as the assumed center of rotation of the mandible, effort and resistance lever arms are plotted and values of $r$ and $F_{L}$ measured as before (Table 4, third part; only the molar region is considered). To obtain $F_{X}$, the 
TABLE 4. Constants for use in calculation of jaw-closing useful power in juvenile Trichechus inunguis.

\begin{tabular}{|c|c|c|c|c|c|c|}
\hline $\begin{array}{l}\text { Muscle } \\
\text { Group }\end{array}$ & $\begin{array}{l}\text { Angle of pull } \\
\text { on lever arm } \\
\text { (parasagittal) }\end{array}$ & $\mathbf{F}$ & $\begin{array}{c}\text { Angle of pull } \\
\text { on lever arm } \\
\text { transverse) }\end{array}$ & $\mathbf{F}$ & $\begin{array}{c}\mathbf{r} \\
\text { (molar) } \\
\text { region) }\end{array}$ & $\begin{array}{c}\mathbf{r} \\
\text { (rostral } \\
\text { region) }\end{array}$ \\
\hline \multicolumn{7}{|c|}{$\begin{array}{l}\text { ORTHAL MOTION: } \\
\text { FULCRUM AT TEMPORAL CONDYLE }\end{array}$} \\
\hline $\mathbf{T}$ & $44^{\circ}$ & 0.71 & $49^{\circ}$ & 0.71 & 0.54 & 0.28 \\
\hline $\mathbf{M}+\mathbf{Z}$ & $40^{\circ}$ & 0.71 & $38^{a}$ & 0.71 & 0.79 & 0.40 \\
\hline PtI & $5^{a}$ & 0.00 & $36^{\circ}$ & 0.71 & 0.92 & 0.47 \\
\hline \multicolumn{7}{|c|}{ FULCRUM AT PTERYGOID-MANDIBULAR JOINT } \\
\hline $\mathrm{T}$ & $71^{\circ}$ & 1.00 & $17^{\circ}$ & 0.27 & 0.91 & \\
\hline $\mathbf{M}+\mathbf{Z}$ & $5^{\circ}$ & 0.00 & $40^{\circ}$ & 0.71 & 0.47 & \\
\hline PtI & $20^{\circ}$ & 0.27 & $29^{\circ}$ & 0.50 & 0.66 & \\
\hline PtE & $13^{\circ}$ & 0.27 & $38^{a}$ & 0.71 & 0.63 & \\
\hline \multicolumn{7}{|c|}{$\begin{array}{l}\text { TRANSVERSE MOTION: } \\
\text { FULCRUM AT TEMPORAL CONDYLE }\end{array}$} \\
\hline $\mathrm{T}$ & $84^{\circ}$ & 1.00 & $41^{\circ}$ & 0.71 & 1.46 & \\
\hline $\mathbf{M}+\mathbf{Z}$ & $89^{\circ}$ & 1.00 & $55^{\circ}$ & 0.87 & 0.16 & \\
\hline PtI & $5^{\circ}$ & 0.00 & $49^{\circ}$ & 0.71 & 0.27 & \\
\hline PtE & $50^{\circ}$ & 0.71 & $59^{a}$ & 0.87 & 0.15 & \\
\hline \multicolumn{7}{|c|}{$\begin{array}{l}\text { FULCRUM AT POINT B, POSTEROMEDIAL TO } \\
\text { PTERYGOID PROCESS }\end{array}$} \\
\hline $\mathrm{T}$ & $67^{\circ}$ & 0.87 & $41^{\circ}$ & 0.71 & 1.08 & \\
\hline $\mathbf{M}+\mathbf{Z}$ & $62^{\circ}$ & 0.87 & $55^{\circ}$ & 0.87 & 0.61 & \\
\hline PtI & $30^{\circ}$ & 0.50 & $49^{\circ}$ & 0.71 & 0.48 & \\
\hline PtE & $29^{\circ}$ & 0.50 & $59^{\circ}$ & 0.87 & 0.64 & \\
\hline
\end{tabular}

directions of pull are projected into the vertical transverse plane (Fig. 48A); but their angles with a horizontal line are measured, rather than with a vertical line as was done before. The resulting values of $E$ are given on the left side of Table 6 . Once again we obtain a zero value for Epti; moreover, the directions of $\mathrm{Em}$ and Epte on the active side are such that they would counteract $\mathrm{Et}$ and tend to move the mandible laterad rather than mediad as is normally the case in transverse chewing. So we are still far from a realistic approximation of the manatee's jaw mechanics.

One of the characteristic features of sirenian jaw structure, and a highly unusual one among mammals, is the extremely massive pterygoid process. The anterolateral and ventrolateral (palatine) surface of this pillarlike process is actually an articular surface of sorts, lying parallel to a corresponding surface on the posteromedial and dorsomedial side of the coronoid arch of the mandible, with a cushion of fascia between (Figs. 45, 48, 50) . If a skull and mandible are properly manipulated, it is at once apparent that the mandible can be retracted against the pterygoid processes and then rotated about a median point lying somewhat abaft the processes, in a manner strongly resembling normal transverse jaw movement. In fact, actual chewing is almost certainly asymmetrical; the mandible is probably in close contact with the pterygoid process only on the active side, so that the center of rotation is offset toward that side. From careful manipulation it appears that point B in Figs . 48 and 49 may be close to the true center of rotation.

If the calculations are redone using this point rather than the condyle as the fulcrum (Tables 4, bottom; 6, right), a much more 
TABLE 5. Jaw-closing useful power (efficiency) data for juvenile Trichechus inunguis, calculated for orthal motion with fulcrum at temporal condyle.

\begin{tabular}{|c|c|c|c|c|c|c|c|c|c|c|}
\hline $\begin{array}{l}\text { Muscle } \\
(\mathrm{M}) \text { as }\end{array}$ & $\begin{array}{c}\text { Mass } \\
\%\end{array}$ & & 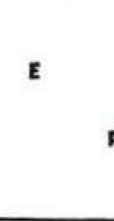 & $\begin{array}{l}\text { MOLAR RE } \\
\% \text { total } \\
\text { adductor } \\
\text { power (comp. } \\
\text { w/muscle } \\
\text { mass) }\end{array}$ & $\begin{array}{l}\text { TANCE REGK } \\
\text { Change in } \\
\% \text { from } \\
\text { direct mus- } \\
\text { cle propor- } \\
\text { tion } \%\end{array}$ & $\begin{array}{l}\text { Propor- } \\
\text { tionote } \\
\text { change }\end{array}$ & E & $\begin{array}{c}\text { ROSTRAL R } \\
\% \text { total } \\
\text { odductor } \\
\text { power (comp. } \\
\begin{array}{c}\text { w muscle } \\
\text { mass) }\end{array}\end{array}$ & $\begin{array}{l}\text { ISTANCE REG } \\
\text { Change in } \\
\% \text { from } \\
\text { direct mus- } \\
\text { cle propor- } \\
\text { tion } \%\end{array}$ & $\begin{array}{l}\text { Propor- } \\
\text { tionate } \\
\text { change }\end{array}$ \\
\hline \multicolumn{11}{|c|}{ INPA-PB 6: } \\
\hline Mt & $=56.1$ & Et & $=15.3$ & 58.0 & +1.9 & $3 \%$ gain & 7.9 & 58.5 & +2.4 & $4 \%$ gain \\
\hline $\mathrm{Mm}$ & $=27.9$ & $\mathrm{Em}$ & $=11.1$ & 42.0 & +14.1 & $51 \%$ gain & 5.6 & 41.5 & +13.6 & $49 \%$ gain \\
\hline Mpti & $=16.0$ & Epti & $i=0.0$ & 0.0 & -16.0 & $100 \%$ loss & 0.0 & 0.0 & -16.0 & $100 \%$ loss \\
\hline Totals & 100.0 & & 26.4 & 100.0 & & & 13.5 & 100.0 & & \\
\hline \multicolumn{11}{|l|}{ INPA-PB 9: } \\
\hline Mt & $=57.8$ & Et & $=15.7$ & 59.0 & +1.2 & $2 \%$ gain & 8.2 & 59.9 & +2.1 & $4 \%$ gain \\
\hline $\mathrm{Mm}$ & $=27.4$ & $\mathrm{Em}$ & $=10.9$ & 41.0 & +13.6 & $50 \%$ gain & 5.5 & 40.1 & +12.7 & $46 \%$ gain \\
\hline Mpti & $=14.9$ & Epti & $i=0.0$ & 0.0 & -14.9 & $100 \%$ loss & 0.0 & 0.0 & -14.9 & $100 \%$ loss \\
\hline Totals & 100.1 & & 26.6 & 100.0 & & & 13.7 & 100.0 & & \\
\hline \multicolumn{11}{|c|}{ INPA-PB 169: } \\
\hline Mt & $=54.4$ & Et & $=14.8$ & 56.5 & +2.1 & $4 \%$ gain & 7.7 & 57.0 & +2.6 & $5 \%$ gain \\
\hline $\mathrm{Mm}$ & $=28.6$ & $\mathrm{Em}$ & $=11.4$ & 43.5 & +14.9 & $52 \%$ gain & 5.8 & 43.0 & +14.4 & $50 \%$ gain \\
\hline Mpti & $=17.0$ & Epti & $i=0.0$ & 0.0 & -17.0 & $100 \%$ loss & 0.0 & 0.0 & -17.0 & $100 \%$ loss \\
\hline Totals & 100.0 & & 26.2 & 100.0 & & & 13.5 & 100.0 & & \\
\hline
\end{tabular}

believable set of figures results. Though dominated by the masseter group, the pterygoidei do play detectable roles, and all pull the mandible mediad with the ipsilateral side active, as expected. Overshadowing all of these, however, is the enormous contribution of the contralateral temporalis, which appears to be the most important factor in transverse chewing, in accord with the fact that the temporales alone constitute more than half the adductor muscle weight, a most unexpected condition for an "ungulate" with transverse chewing. It must of course be remembered that no one diagram can show all the important functions of any of these muscles; the masseter, for instance, has major roles in both orthal and transverse movements, and the contralateral pterygoideus externus and ipsilateral temporalis are probably important in the recovery stroke.

The significance of the hypothesized position of the fulcrum can be further demon- strated by vector analysis of the forces acting at the fulcrum. In Fig. 49, the temporalis, masseter, and pterygoideus effort vectors, scaled to the weights of the respective muscle groups (but not corrected for the muscle alignment factors), are summed sequentially, with the hypothetical fulcrum ( $A$ or $B$ ) serving as origin of the temporalis vector in each case. Both vector sums leave large unresolved forces (marked by feathered arrows) tending to translate the fulcrum posteromediad. With the fulcrum at $A$ there is no means of resisting this force; but with the fulcrum at $B$, an extension (marked by $\mathrm{X}$ ) of the corresponding force vector through point B almost precisely intersects the pterygoid-mandibular articulation perpendicular to its surface. This shows that this joint is properly located to resist translation of the center of rotation, and independently confirms the assumption that the pterygoid process and mandible are closely appressed on the active side in transverse chewing. 
With respect to orthal motion, if we resolve the parasagittal forces at the jaw joint as is done in Figs. 45 and 46 , we find large unresolved posterodorsad forces of the temporalis which are only partly counteracted by the masseter-zygomaticomandibularis. In mammals such as carnivores, a force of this sort would be resisted by a stout postglenoid process. In sirenians, however, the postglenoid process is very small and located behind a distinct mandibular fossa, much as in humans, and it seems not to come into contact with the mandible or play any apparent role in chewing. Thus, since the unresolved force of the temporalis cannot be resisted at the temporal joint, it must be resisted either at the pterygoidmandibular joint or at the only other point of contact between the skull and mandible, i.e., the food between the teeth.

Under the former assumption, the contraction of the temporalis would first retract the mandible, sliding the condyle back into the mandibular fossa and bringing the coronoid arch against the pterygoid process, as noted earlier in regard to manipulation of the bones. Subsequent contraction would rotate the jaw upward around the pterygoid-mandibular joint as fulcrum, as shown in Fig. 50. If we resolve the forces acting at this joint, using values of E calculated with this point considered as fulcrum (Table 4, second part; Table 7!, we find the unresolved force aligned posterodorsad, nearly parallel to the long axis of the pterygoid process and against the pterygoidmandibular joint surface - clearly a favorable arrangement for resisting the force. This force also has a laterad component (not illustrated) tending to separate the pterygoid process and mandible, but thanks to the solidly fused mandibular symphysis this component is either cancelled by the equivalent force on the opposite side (if the jaw muscles on both

TABLE 6. Masticatory useful power (efficiency) data for juvenile Trichechus inunguis, calculated for molar resistance region and transverse motion.

\begin{tabular}{|c|c|c|c|c|c|c|c|c|c|}
\hline \multirow[b]{2}{*}{$\begin{array}{l}\text { Muscle Mass } \\
(M) \text { as \% }\end{array}$} & \multicolumn{5}{|c|}{ FULCRUM AT TEMPORAL CONDYLE } & \multicolumn{4}{|c|}{ FULCRUM AT POINT B } \\
\hline & \multicolumn{3}{|c|}{$\begin{array}{l}\% \text { totol } \\
\text { odductor } \\
\text { power (eomp. } \\
\text { w/muscle } \\
\text { moss) }\end{array}$} & $\begin{array}{l}\text { Change in } \\
\% \text { from } \\
\text { direct mus- } \\
\text { cle propor- } \\
\text { tion } \%\end{array}$ & $\begin{array}{l}\text { Propor- } \\
\text { tionate } \\
\text { change }\end{array}$ & $\mathbf{E}$ & $\begin{array}{l}\% \text { total } \\
\text { adductor } \\
\text { power (eomp. } \\
\text { w/muscle } \\
\text { moss) }\end{array}$ & $\begin{array}{l}\text { Change in } \\
\% \text { from } \\
\text { direct mus- } \\
\text { cle propor- } \\
\text { tion } \%\end{array}$ & $\begin{array}{l}\text { Propor- } \\
\text { tionate } \\
\text { change }\end{array}$ \\
\hline \multicolumn{10}{|l|}{ INPA-PB 6: } \\
\hline Mt $=51.4$ & Et & $=53.3$ & 92.4 & +41.0 & $80 \%$ gain & 34.3 & 67.4 & +16.0 & $31 \%$ gain \\
\hline $\mathrm{Mm}=25.5$ & $\mathrm{Em}$ & $=3.6$ & 6.2 & -19.3 & $76 \%$ loss & 11.8 & 23.2 & -3.1 & $12 \%$ loss \\
\hline Mpti $=14.7$ & Epti & $=0.0$ & 0.0 & -14.7 & $100 \%$ loss & 2.5 & 4.9 & -9.8 & $67 \%$ loss \\
\hline Mpte $=8.4$ & Epte: & $=0.8$ & 1.4 & -7.0 & $83 \%$ loss & 2.3 & 4.5 & -3.9 & $46 \%$ loss \\
\hline Totals & & 57.7 & 100.0 & & & 50.9 & 100.0 & & \\
\hline \multicolumn{10}{|l|}{ INPA-PB 9: } \\
\hline Mt $=53.6$ & Et & $=55.6$ & 93.0 & +39.4 & $74 \%$ gain & 35.8 & 69.0 & +15.4 & $29 \%$ gain \\
\hline $\mathrm{Mm}=25.4$ & Em & $=3.5$ & 5.9 & -19.5 & $77 \%$ loss & 11.7 & 22.5 & -2.9 & $11 \%$ loss \\
\hline Mpti $=13.8$ & Epti & $=0.0$ & 0.0 & -13.8 & $100 \%$ loss & 2.4 & 4.6 & -9.2 & $67 \%$ loss \\
\hline Mpte $=1.1$ & Epte & $=0.7$ & 1.2 & -5.9 & $83 \%$ loss & 2.0 & 3.9 & -3.2 & $45 \%$ loss \\
\hline Totals & & 59.8 & 100.1 & & & 51.9 & 100.0 & & \\
\hline \multicolumn{10}{|l|}{ INPA-PB 169: } \\
\hline$M t=50.9$ & Et & $=52.8$ & 92.5 & +41.6 & $82 \%$ gain & 34.0 & 66.8 & +15.9 & $31 \%$ gain \\
\hline $\mathrm{Mm}=26.7$ & $\mathrm{Em}$ & $=3.7$ & 6.5 & -20.2 & $76 \%$ loss & 12.3 & 24.2 & -2.5 & $9 \%$ loss \\
\hline Mpti $=15.8$ & Epti & $=0.0$ & 0.0 & -15.8 & $100 \%$ loss & 2.7 & 5.3 & -10.5 & $66 \%$ loss \\
\hline Mpte $=6.7$ & Epte & $=0.6$ & 1.1 & -5.6 & $84 \%$ loss & 1.9 & 3.7 & -3.0 & $45 \%$ loss \\
\hline Totals & & 57.1 & 100.1 & & & 50.9 & 100.0 & & \\
\hline
\end{tabular}


sides contract together) or resisted by the contralateral pterygoid process (if the muscles on only one side contract). Using the pterygoid-mandibular joint as fulcrum might seem to have the additional advantage of lowering the functional jaw joint almost to the level of the tooth row, giving the temporalis a great mechanical advantage as in carnivores; this. however, is more than cancelled out by the reduced mechanical advantage in the transverse plane (FX, Table 4), so that the absolute useful power of the temporalis is reduced despite its gain relative to the other adductors. Moreover, the pterygoideus internus opposes rather than assists the temporalis, and the large unresolved force of the temporalis is wasted in compression of the pterygoid process.
These problems are avoided if the point of skull-mandible contact is considered to be the food itself, as described by Gingerich (1971). In this model, the contraction of the temporalis retracts the mandible as above, but this force is resisted by the food rather than the pterygoid process; thus virtually the entire force of the temporalis is used directly in mastication without any lever systems being involved. This is indicated in Fig. 45 by the extension (marked by $\mathrm{X}$ ) of the temporalis effort vector through the molar resistance field; compare fig. 3 of Gingerich (1971). The mandible acts merely as a link between the temporalis (acting at the coronoid process) and the teeth. This is made possible by the sliding jaw joint, which has a very similar structure in sirenians and in man (the example

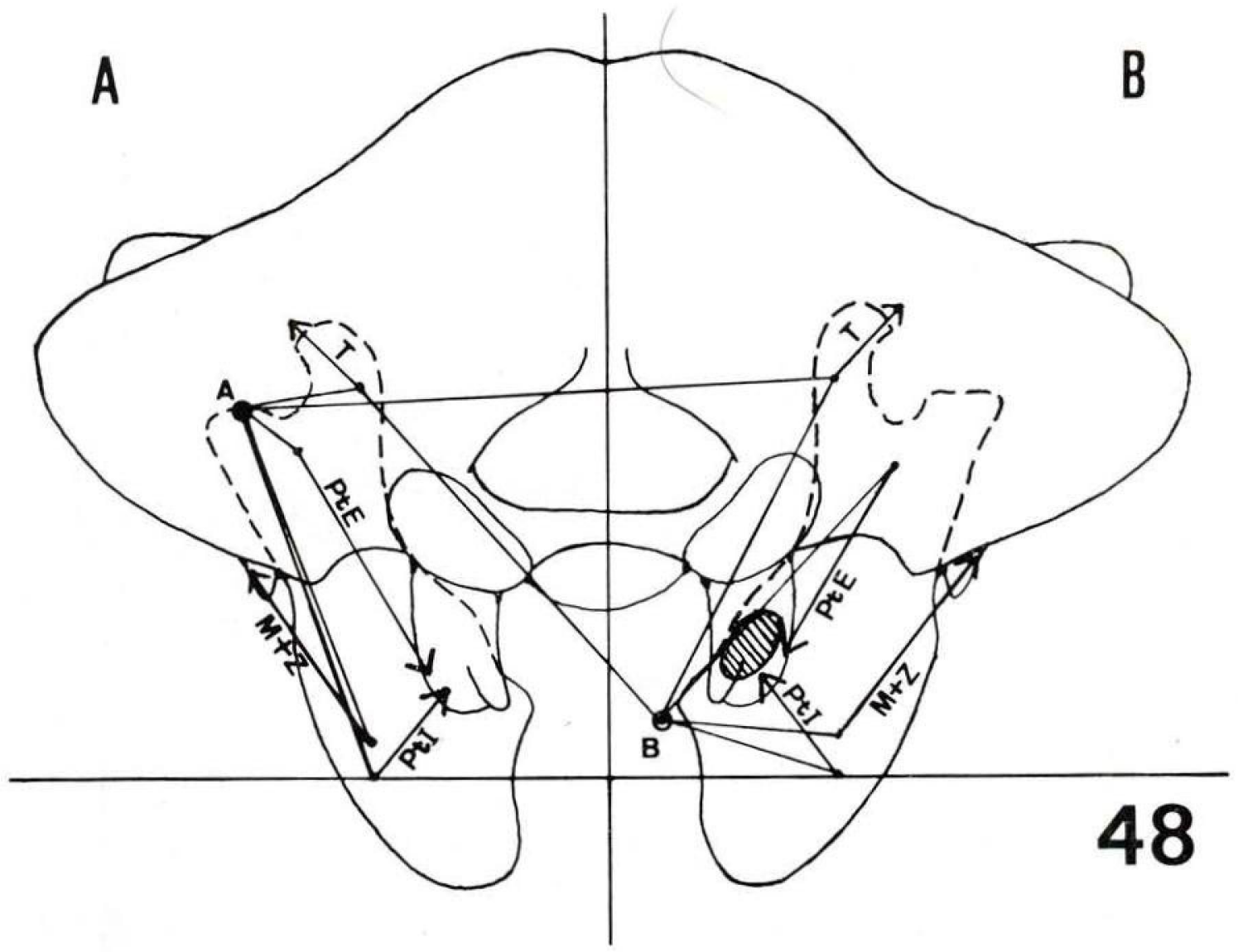

Fig. 48-Posterior view of articulated skull and mandible, for analysis of orthal and transverse jaw movements. On each side, arrows connect functional midpoints of attachment fields of temporalis, masseter + zygomaticomandibularis, pterygoideus internus, and pterygoideus externus and show average directions of pull. On side A, effort lever arms are drawn to the temporal condyle $(A)$ as fulcrum; on side $B$, to a point $(B)$ ventromedial to pterygoid process, here considered the center of rotation in transverse chewing. Effort lever arms are shown for both ipsilateral and contralateral temporales. Bertical and horizontal lines are used to measure muscles' angles of pull and estimate $F_{X}$ (see text). Cross-hatched area is pterygoid-mandibular articular surface. Dashed lines show outlines of concealed ascendling rami of mandible. 


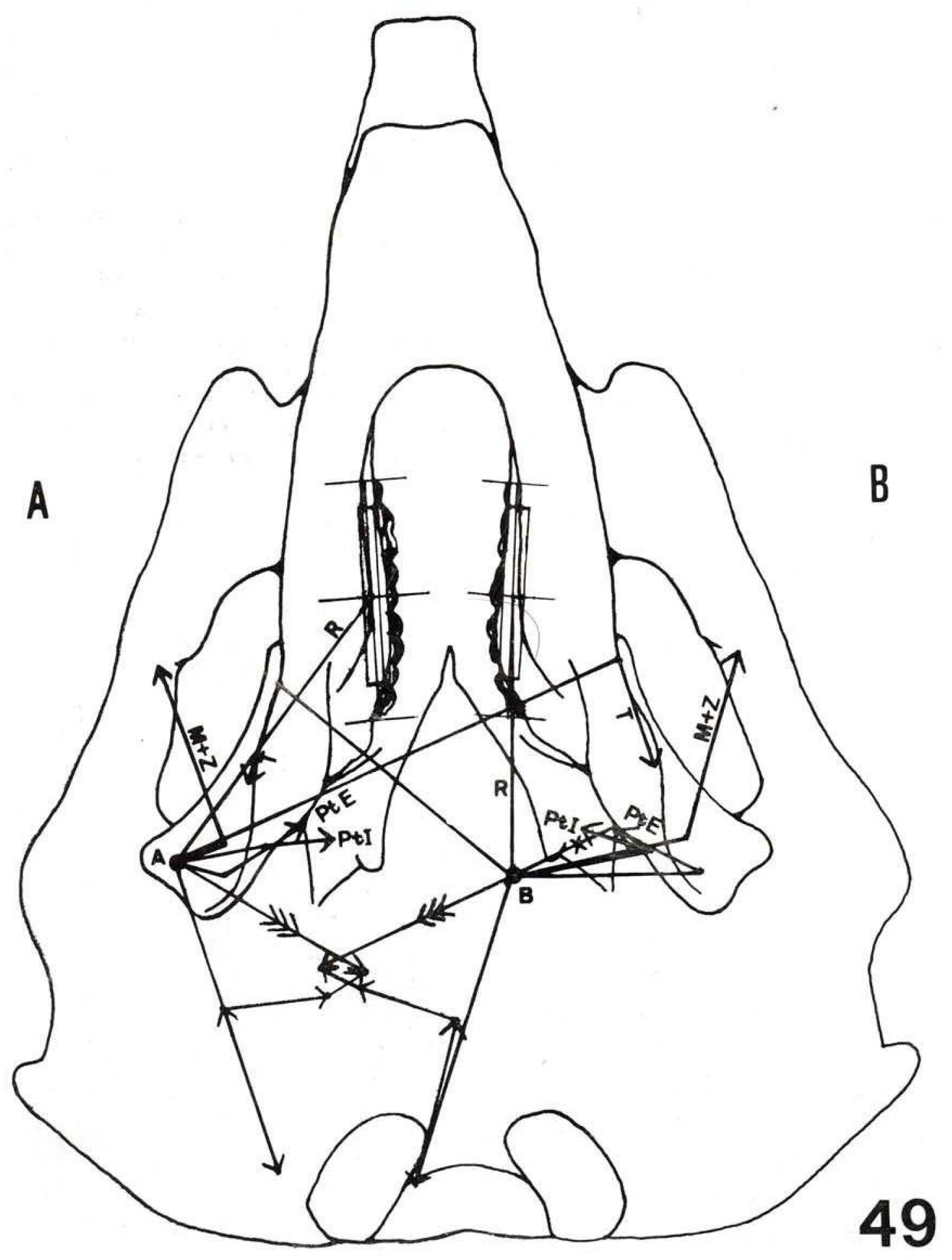

Fig. 49. - Ventral view of articulated skull and mandible, illustrating two hypotheses of transverse jaw movement. On each side, arrows connect functional midpoints of attachment fields of temporalis, masseter + zygomaticomandibularis, pterygoideus internus, and pterygoideus externus and show average directions of pull. On side $\mathrm{A}$, resistance $(R)$ and effort lever arms are drawn to the temporal condyle (A) as the hypothetical fulcrum; on side $B$, to a point (B) posteromedial to pterygoid process. In lower part of figure, effort vectors, proportioned to muscle weights, for each of the two hypothetical lever systems are summed, with origins at the fulcra; unresolved translational force vectors are marked by feathered arrows, and an extension through point $B$ of the vector on side $B$ is marked by $X$. Force vector resolutions for individual muscle groups not shown. 
TABLE 7. Jaw-closing useful power (efficiency) data for juvenile Trichechus inunguis, calculated for molar resistance region and orthal motion with fulcrum at pterygoid-mandibular joint. Pterygoideus internus included for comparison though it does not act as an adductor; see Fig. 50.

\begin{tabular}{|c|c|c|c|c|}
\hline $\begin{array}{l}\text { Muscle Mass } \\
\text { (M) as \% }\end{array}$ & $\mathbf{E}$ & $\begin{array}{l}\% \text { total adductor } \\
\text { power (comp. w/ } \\
\text { muscle mass) }\end{array}$ & $\begin{array}{c}\text { Change in } \% \\
\text { from direct muscle } \\
\text { proportion } \%\end{array}$ & $\begin{array}{c}\text { Proportionate } \\
\text { change }\end{array}$ \\
\hline \multicolumn{5}{|l|}{ INPA·PB 6: } \\
\hline $\mathrm{Mt}=51.4$ & $\mathrm{Et}=14.8$ & 86.5 & +35.1 & $68 \%$ gain \\
\hline $\mathrm{Mm}=25.5$ & $\mathrm{Em}=0.0$ & 0.0 & -25.5 & $100 \%$ loss \\
\hline Mpti $=14.7$ & Epti $=1.3$ & 7.6 & -7.1 & $48 \%$ loss \\
\hline Mpte $=8.4$ & Epte $=1.0$ & 5.8 & -2.6 & $31 \%$ loss \\
\hline Totals $\quad 100.0$ & 17.1 & 99.9 & & \\
\hline \multicolumn{5}{|l|}{ INPA-PB 9: } \\
\hline $\mathrm{Mt}=53.6$ & Et $=13.2$ & 86.3 & +32.7 & $61 \%$ gain \\
\hline $\mathrm{Mm}=25.4$ & $\mathrm{Em}=0.0$ & 0.0 & -25.4 & $100 \%$ loss \\
\hline Mpti $=13.8$ & Epti $=1.2$ & 7.8 & -6.0 & $43 \%$ loss \\
\hline Mpte $=7.1$ & Epte $=0.9$ & 5.9 & -1.2 & $17 \%$ loss \\
\hline Totals & 15.3 & 100.0 & & \\
\hline \multicolumn{5}{|l|}{ INPA-PB 169: } \\
\hline $\mathrm{Mt}=50.9$ & $E t=12.5$ & 85.0 & +34.1 & $67 \%$ gain \\
\hline $\mathrm{Mm}=26.7$ & $\mathrm{Em}=0.0$ & 0.0 & -26.7 & $100 \%$ loss \\
\hline $\mathrm{Mpti}=15.8$ & Epti $=1.4$ & 9.5 & -6.3 & $40 \%$ loss \\
\hline Mpte $=6.7$ & Epte $=0.8$ & 5.4 & -1.3 & $19 \%$ loss \\
\hline Totals & 14.7 & 99.9 & & \\
\hline
\end{tabular}

used by Gingerich). It is also in accord with the fact that the initially-formed wear facets on the teeth, especially as seen in juvenile animals, lie in posterodorsad-sloping planes, indicating a large amount of jaw movement in this direction.

This appears to be the most likely mechanism of orthal motion, in which the temporalis provides the main adductive force and the pterygoideus externus acts to slide the jaw joint downward and forward on the return stroke. The pterygoideus internus and masseter-zygomaticomandibularis seem to play no role, unless the latter serve to rotate the mandible about the condyle at the beginning of a bite. The anterad lengthening of the coronoid process seen in Trichechus in contrast to other sirenians is advantageous to the temporalis under any of the above models. and is evidently an adjustment to the unusual length of the tooth row in this genus.
It is in transverse chewing that the masseter and pterygoideus internus probably play their principal roles, though in subordination to the contralateral temporalis, as described above. The pterygoideus internus is probably much more efficient than Table 6 would suggest, as it can to some degree act directly (anteromediad) against the food, in a manner analogous to the temporalis in orthal motion. The contralateral temporalis adds to this a larger posteromediad component. It is questionable whether the posteromediad resultant can be completely absorbed by the food; if not, it would be resisted at the pterygoid-mandibular joint as demonstrated above, and this seems to be the besi explanation of the massive pterygoid process.

These hypotheses of sirenian jaw mechanics need to be tested further by examination of the orientation of wear surfaces on the teeth, in order to independently locate the 
center of mandibular rotation (cf. Kay and Hiiemae, 1974). For determining its location in the horizontal plane, at least, Dugong might be an ideal animal, as its teeth have flat occlusal surfaces marked by striations which should be concentric to the center of rotation. The entire picture also needs to be reevaluated in more detail than space here permits, and in less artificially simplified fashion; in particular, the role of the zygomaticomandibularis, which is undoubtedly distinct from that of the masseter, needs to be clarified. The present results should be regarded as no more than a first approximation.

How, then, do the jaw mechanics of the manatee compare with those of the other mammals described by Turnbull (1970)? I had earlier (Domning, 1977a) supposed that Dugong and other sirenians would fit into the "ungulate-grinding" category (Specialized Group II) of Turnbull. This is now seen, at least for Trichechus, to be very far from the truth. In terms of adductor muscle mass (M), the manatee is most comparable to the forms of Turnbull's Generalized Group, especially the primates (including Homo). In terms of useful power (E), however, it more resembles the carnivores (Specialized Group I), and indeed is more extreme in this direction than any carnivore because of the negligible contribution of the pterygoidei to orthal jaw-closing about the condyle. Clearly the Sirenia must be placed in a separate, specialized group of their own, which can be characterized as

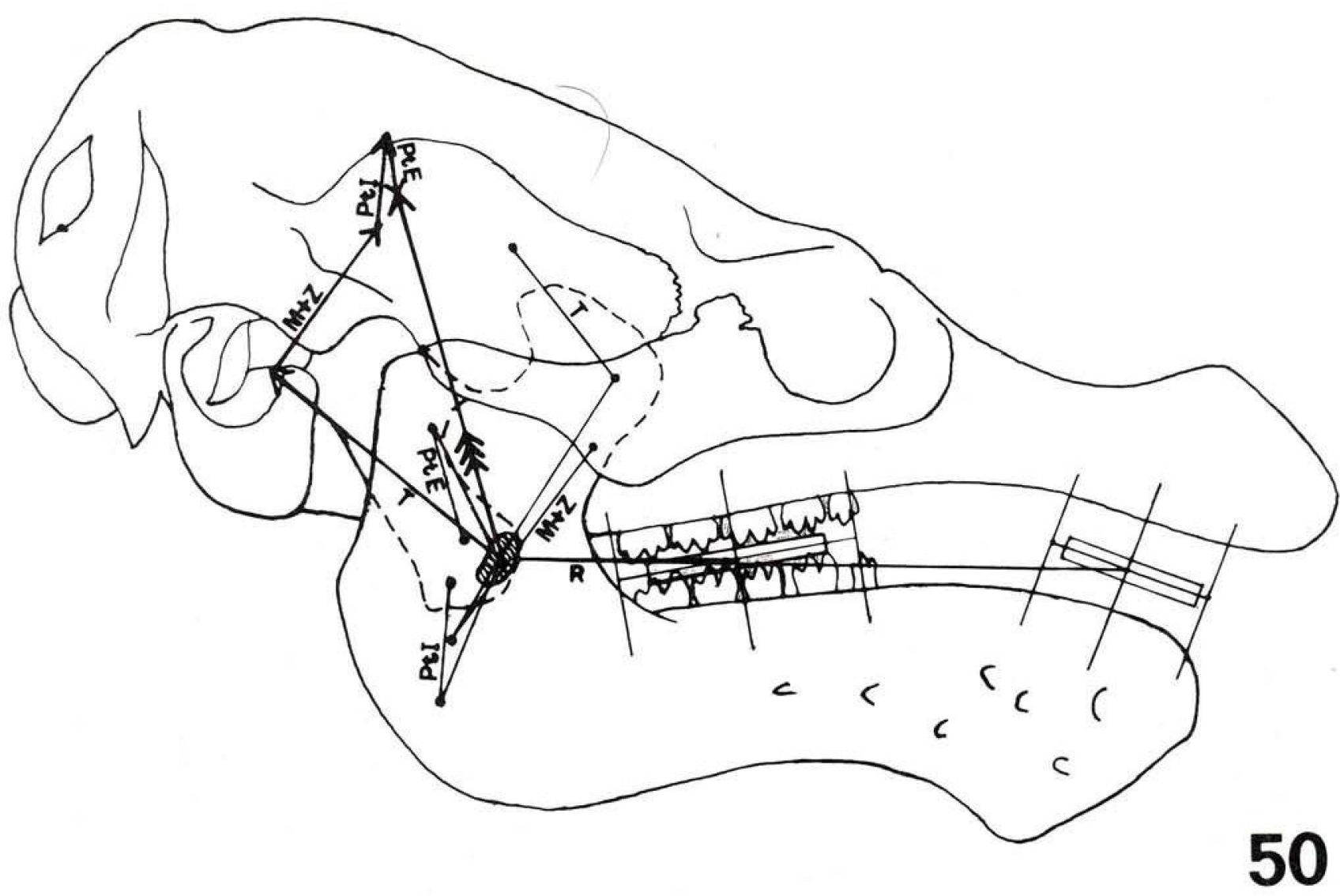

Fig. 50 - Lateral view of skull and mandible, illustrating effort and resistance lever arms of jaw muscles and resultant forces for molar resistance region in orthal movement when fulcrum is considered to lie at pterygoid-mandibular articulation (cross-hatched area). Summed vectors (open-headed arrows) shown are unresolved forces produced at fulcrum by each muscle group, determined as in Figs. 45-47; feathered arrow marks resultant vector of total unresolved force at fulcrum. 
follows: the temporalis is very large (constituting more than half of the adductor muscle mass), and gains significantly in useful power over the other muscles; the masseter and zygomaticomandibularis are well-developed, and important both in orthal chewing when the condylar joint acts as fulcrum, and in transverse chewing; the pterygoideus internus is probably important mainly in transverse chewing; the pterygoideus externus serves not as an adductor but more probably in an auxiliary role, such as in recovery strokes; a pterygoid-mandibular articulation is developed and probably of major importance in transverse chewing, where it serves to absorb otherwise unresolved resultant forces.

\section{NECK MUSCLES}

(Note: Wet weights of some neck, limb, and other muscles which were taken in the course of this study are presented in Table 8; however, vector analysis of these muscle systems will not be attempted at this time).

TABLE 8. Weights of some muscles of juvenile Trichechus inunguis (grams). Left and right sides combined; asterisk (") marks weights which pertain to only one side; $\mathrm{e}=$ estimated.

\begin{tabular}{lc}
\hline \multicolumn{1}{c}{ Muscle } & INPA-PB 6 \\
\hline \multicolumn{2}{c}{} \\
Platysma pars jugularis + & \\
$\quad$ cutaneus trunci & 523.2 \\
Sphincter colli profundus & \\
pars auris & 115.5 \\
Mandibularis & 2.6 \\
Mentalis & 4.7 \\
Sternohyoideus & $2.9 \mathrm{e}$ \\
Thyrohyoideus & 0.70 \\
Geniohyoideus & 2.6 \\
Splenius & 19.2 \\
Semispinalis capitis & 50.3 \\
Semispinalis & 139.8 \\
Longissimus dorsi & 353.0 \\
Iliocostalis dorsi & 50.0 \\
Rectus capitis dorsalis & \\
$\quad$ intermedius & $10.3 \mathrm{e}$ \\
Rectus capitis dorsalis minor & $6.5 \mathrm{e}$ \\
Rectus capitis lateralis & 7.0 \\
Rectus capitis ventralis & 1.0 \\
Sternothyroideus & $3.3 \mathrm{e}$ \\
\hline
\end{tabular}

Muscle

INPA-PB 6 INPA-PB 9

Scalenus (superficial)

7.2

Scalenus (deep).

1.1

Longus capitis

6.8

Longus colli

2.3

Intercostales externi and interni

Intercartilaginei

2.4

Sternocostalis

Diaphragm

2.5

89.7

Obliqui abdominis externus and internus

73.4

Transversus abdominis

Rectus abdominis

82.6

79.2

Intertransversarius coccygeus

Sacrococcygeus ventralis lateralis

Sacrococcygeus ventralis medialis

Trapezius

Rhomboideus

Serratus magnus

Latissimus dorsi

Pectoralis major

Pectoralis minor

Deltoicleus

Supraspinatus

Infraspinatus

Subscapularis

Teres major

Coracobrachialis

Biceps brachii

Triceps brachil, long head

Triceps brachii, lateral head

Triceps brachil, medial head

Brachialis

Brachioradialis

Extensor carpi radialis

Extensor digitorum communis

Extensor digiti quinti

Extensor carpi ulnaris

Extensor pollicis

Flexor carpi radialis

Palmaris longus

Flexor digitorum

Flexor carpi ulnaris

Abductor digiti quinti

Flexor digiti quinti brevis

Flexor pollicis brevis

Lumbricalis III

Lumbricalis IV

Lumbricalis $\mathrm{V}$

Interosseus II

Interosseus III

Interosseus IV

Interosseus $\mathrm{V}$
40.6

$75.8 e$

$239.5 \mathrm{e}$

36.6

$6.9^{*}$

$20.7^{*}$

22.6

35.2

12.6

16.1

28.3

23.0

52.0

19.9

6.2

$25.0^{*}$

$13.6^{*}$

44.0

26.4

60.8

$16.2^{*}$

$0.7-1.9$

$9.0 \quad 11.8$

$4.1 \quad 4.6$

$3.5 \quad 5.0$

$9.6 \quad 12.3$

$2.4 \quad 1.9$

$1.9 \quad 1.7$

$2.8 \quad 3.5$

$1.7 \quad 1.4$

$1.5 \quad 1.9$

$1.8 \quad 2.3$

$2.3 \quad 1.8$

0.1 *

$6.2 \quad 8.3$

$5.7 \quad 3.7^{\circ}$

$1.8 \quad 0.3^{*}$

$0.7 \quad 0.2^{*}$

$0.2 \quad 0.1^{*}$

$0.7 \quad 0.3^{*}$

$1.3 \quad 0.4^{\circ}$

$1.8 \quad 1.0^{\circ}$

$1.20 .5^{\circ}$

$1.10 .6^{\circ}$

$1.10 .8^{\circ}$

$0.4 \quad 0.4^{\circ}$ 
The Amazonian manatee is characterized by several striking features of the occipital region of the skull. There is a well-developed sigmoid ridge on the squamosal, as in other living and in primitive sirenians. The supraoccipital, however, is swollen to a unique degree, so that its posterior surface is roughly perpendicular to the dorsal side of the cranium, in contrast to the $50^{\circ}-60^{\circ}$ parietal-supraoccipital angles seen in other manatees. A distinct, rugose and posteriorly overhanging flange is developed on the dorsolateral border of the exoccipital, and shallow fossae just dorsal to the occipital condyles are often present on one or both sides. The former feature is developed, though to a much lesser degree, in some $T$. senegalensis, and not at all in $T$. manatus; while the latter feature is not seen in other manatees although it is better developed in Dugong than in $T$. inunguis. The development of supracondylar fossae, which receive the dorsal edges of the atlas cotyles at maximum extension of the atlantooccipital joint, is accompanied by a very slight but distinct anterodorsal and inward curvature of the dorsal part of the occipital condyle, whereas in sirenians lacking supracondylar fossae, such as $T$. manatus, the dorsal part of the condylar articular surface is nearly vertical and its dorsal edge stands well out from the surface of the occiput. (These differences are epitomized in the fact that an adult skull of $T$. inunguis can always be balanced upright on its occiput on a horizontal surface, in contrast to $T$. manatus and most $T$. senegalensis.).

The sigmoid riuge serves for the insertion of the splenius, which turns the head laterally. The supraoccipital bears the insertions of the semispinalis capitis and rectus capitis dorsalis muscles, levators of the head; its thickened condition in $T$. inunguis (seen in the adult but not the young) suggests an unusually high degree of activity of these muscles, producing stress on the bone surface and causing deposition of additional bone. The exoccipital border receives part of the insertion of the semispinalis capitis in Dugong (Domning, 1977a) and apparently in $T$. manatus, but in $T$. inunguis it receives the rectus capitis lateralis instead, as noted above. As the latter muscle arises only from the atlas, the ex- tension of the neck produced by the muscles inserting on the exoccipital border has, in $T$. inunguis, become restricted to the atlantooccipital joint. The details of this joint just noted, together with the development of a prominent flange at the rectus lateralis insertion, further corroborate the emphasis on atlantooccipital extension which has evolved in $T$. inunguis. We may further note that the longissimus capitis, which turns the head laterally in Dugong and $T$. manatus, is completely absent in $T$. inunguis.

Elsewhere (Domning, 1977b) I have proposed the hypothesis that degree of rostral deflection in sirenians is inversely proportional to degree of specialization for feeding on floating or other near-surface vegetation. The living species of Trichechus provide an opportunity to test this hypothesis, as they differ significantly (at the .001 level) in degree of deflection of the rostrum from the palatal plane, with mean values of $38.2^{\circ}$ in T. manatus (observed range $=24^{\circ}-52^{\circ}, \mathrm{N}=72$ ), $30.4^{\circ}$ in $T$. inunguis (OR $=25^{\circ}-36^{\circ}, N=35$ ), and $25.8^{\circ}$ in $T$. senegalensis (OR $=15^{\circ}-40^{\circ}, \mathrm{N}=20$ ).

Trichechus manatus is known to feed both in fresh water, where it takes plants located anywhere between the bottom and the surface (Hartman, 1971), and in salt water, where the available food plants are for the most part seagrasses growing on the bottom (Hartman, 1974). In the Amazon basin, where submerged aquatic plants are relatively scarce (Sioli, 1968), $T$. inunguis feeds predominantly on the "floating meadows" and other natant and nearsurface vegetation (Pereira, 1944). The food habits of $T$. senegalensis are practically unknown, but should be more similar to those of $T$. inunguis than $T$. manatus due to its largely riverine habitat.

At least for the former two species, then, there appears to be a correlation between rostral deflection and location of principal food plants, $T$. manatus being quite generalized while $T$. inunguis is more specialized for surface-feeding. The condition of the neck joint and muscles clearly support this conclusion, indicating that the Amazonian manatee's adaptations to surface-feeding include habitual sharp bending upward of the head to reach floating plants. As $T$. inunguis normally 
assumes an oblique rather than horizontal attitude of the body axis while feeding at the surface (personal observation), the mecharism I proposed for elevation of the head in Hydrodamalis, involving reduced rather than increased extension of the atlantooccipital joint and permitting the body axis to remain horizontal (Domning, 1977b), need not be invoked here. It remains to be seen whether $T$, senegalensis, with a very slight rostral deflection but a more manatus-like occiput, is merely intermediate between the other two manatee species or is divergently specialized.

A large exoccipital flange is also found in the extinct Hydrodamalis and its Late Miocene ancestors, where I interpreted it, by analogy with Dugong, as an expanded attachment for the semispinalis capitis (Domning, 1977b). I went on to suggest that this was an adaptation for more effective lateral bending of the neck. In Hydrodamalis, however, unlike $T$. inunguis, the sigmoid ridge, and presumably the splenius, were very reduced, so that compensating modification of another muscle, such as the semispinalis capitis, to take over part of its function might be reasonably expected. If, however, the exoccipital flange in hydrodamalines was occupied by the rectus capitis lateralis as in $T$. inunguis, this would only strengthen my argument that Hydrodamalis, like $T$. inunguis, was specialized for surface-feeding. The fact that it lacked supracondylar fossae and a swollen supraoccipital, and the fact that supracondylar fossae are present in Dugong (a highly specialized bottom-feeder). only emphasize that adaptation to "surfacefeeding" (for example) has proceeded in different ways in different lineages. Certainly the "surface-feeding" of Hydrodamalis, a large animal in a high-energy environment, imposed different functional requirements than that of $T$. inunguis, a small animal feeding in quiet waters. Specialization of sirenians to such a nich is a complex phenomenon in which the roles and relative importance of the anatomical modifications are not yet fully understood.

\section{- FORELIMB MUSCLES}

Like other anatomical and functional differences between the species of Trichechus, the differences seen in the forelimb have not received adequatc attention, although one major study (Bahrdt, 1933) has documented some of the skeletal and ontogenetic aspects. It has been recognized (e.g. by Hatt, 1934) that the forelimbs (particularly the metacarpals and phalanges) of $T$. inunguis are proportionately longer than in the other species, and of course lack nails. The presence of a bicipital groove on the humerus of $T$. inunguis was demonstrated long ago by Cuvier (1809: pl. 19: fig. 17; the specimen illustrated, though said to be "from Cayenne", has been recognized to be $T$. inunguis at least since Stannius, 1845: 25-26) This, however, was forgotten by later writers e.g., Howell, 1930: 228; Simpson, 1932: 490; Domning, 1977a: 31), who apparently assumed from the conditions in $T$. manatus that all manatees lack a bicipital groove. Bahrdt (1933: 200, 202, 204) noted that it is present though very weakly developed in $T$. senegalensis, and, moreover, even observed it in a 13.6 $\mathrm{cm}$ embryo of $T$. manatus (1933: 198), which suggests that its absence in adults is a derived condition. The possible significance of these differences, however, has never been explored.

The contrast in proportions of limb segments between $T$. inunguis and the other species is startling: compare the illustrations of $T$. inunguis and $T$. senegalensis in figs. 9 and 11 of Bahrdt (1933). Even in these immature specimens, the digits of $T$. inunguis are strikingly elongated and make the limb truly finlike, bearing little resemblance to the stubby fingers of $T$. senegalensis (likewise $T$. manatus). The humerus and forearm, respectively, in this $T$. inunguis make up $31 \%$ and $22 \%$ of the total limb length, compared to $39 \%$ and $27 \%$ in the $T$. senegalensis (Bahrdt, 1933 269). As the latter animal was smaller and presumably younger than the former, and as the proximal limb segments increase in relative length during growth (Bahrdt, 1933:206), the difference might be even greater at maturity.

If an analogy can be made with terrestrial mammals, the long distal elements of $T$. inunguis certainly give its flipper a "cursorial" appearance compared to the more "gravigrade" limb proportions of the other species. But we need not go so far afield; Howell (1930: 232) 
has shown that in aquatic mammals in general the proximal limb segments tend to become shortened with increasing aquatic specialization. If we then take as a working hypothesis the proposition that the flipper of $T$. inunguis is in some sense a more refined swmming organ than those of other manatees, we can try to interpret the other observed differences in this light.

In addition to the bicipital groove, the proximal humerus of $T$. inunguis is distinguished by a greater tuberosity which extends well proximad of the head of the humerus. This process provides the supraspinatus, the principal extensor of the forelimb, with a much more effective lever arm than it has, for example, in $T$. manatus, where the greater tuberosity hardly extends proximad of the head. Moreover, the insertion of the infraspinatus has become elongated proximomediad to a point almost or quite level with the proximal side of the head and almost reaching the supraspinatus insertion, thereby giving the infraspinatus additional advantage in extending the humerus as well as rotating it laterally. All this would lead us to expect strong movements of extension at the shoulder joint of $T$. inunguis, Coupled with the drag produced by the elongated manus, this would tend in turn to force passive extension of the elbow. It is, however, precisely in $T$. inunguis that we find the peculiar accessory tendon of the biceps, whose apparent action as a "check ligament" to resist extension of the elbow has already been noted. Such forceful extensional movements would most likely be recovery strokes, made with the flipper feathered, and alternating with backward propulsive strokes made with the elbow abducted, the humerus being simultaneously adducted, elevated (flexed), and medially rotated. The muscular portion of the biceps, stretched over the bicipital groove during this power stroke, might aid in quickening the recovery strake by its elasticity.

In $T$. manatus, on the other hand, these features are lacking. so we might expect extension of its shoulder to be less forceful, though why the bicipital groove should be lost is unclear; perhaps the biceps has become specialized as an adductor.
Thus the conditions in $T$. inunguis result in a more oarlike flipper with its fulcrum at the shoulder joint and with extra stiffening to counter drag on recovery strokes; and this is clearly a step in the direction of greater aquatic specialization. Why $T$. inunguis should use the flippers for such forward propulsion more than the other species, however, is far from clear. One possibility is that $T$. inunguis, in a habitat with few bottom plants, seldom has occasion to travel for any distance in close proximity to the bottom, or, consequently, to use the flippers for traction on the bottom; accordingly its flippers have adapted to a more "pelagic" life. T. manatus, on the other hand, may more frequently propel itself by pushing against the bottom, as Hartman (1971) has described. The difference may thus lie not in the degree of use of the flippers for propulsion, but in the absence or presence of a solid substrate. This could explain both the stubby, "gravigrade" digits and the retention of nails in $T$. manatus and $T$. senegalensis, the latter structures serving to protect the edge of the flipper against abrasion; it might also call for the extra strength in adduction that the specialized biceps of $T$. manatus may provide. This hypothesis, of course, suffers from the dearth of knowledge of the ecology of $T$. senegalensis, as well as the fact that nails are lacking in Dugong, which travels extensively along the bottom in feeding.

In Dugong, we find a shoulder structure very different from that of the manatees, and, as I suggested previously (Domning, 1977a: 31), the dugong has apparently evolved a strong emphasis on parasagittal movements of the limb. The long insertion and separate cephalic portion of the trapezius and the peculiar platysma pars scapularis, together with the rhomboideus and divided serratus magnus, seem well adapted to rotate the elongated and falciform scapula and scapular cartilage on the side of the rib cage. Apart from the extra leverage of the trapezius' attachment to the elongated acromion process, Trichechus has no such specializations for scapular rotation; even its scapular cartilage is much abbreviated, despite the similarity in shape of the scapula itself to that of Dugong. The olecranon of Dugong is much better de- 
veloped than that of Trichechus, giving the triceps much greater leverage in extending the elbow. The biceps is large and muscular, clearly playing an active rather than a passive role in movements of the limb. The much more distal insertion of the pectoralis minor makes it an adductor rather than an abductor and gives it a role in forward propulsion. The latissimus dorsi, by inserting with the pectorales rather than the teres major, may be able to rotate the humerus medially through a greater arc during a propulsive stroke; perhaps more importantly, its origin from the cutaneus trunci rather than the ribs may extend its effective fiber length over much of the length of the trunk, giving it a tremendous fore-and-aft excursion at its insertion. The manatee, on the other hand, may be better adapted for abductive and adductive movements; its elongate acromion porcess may aid the deltoideus in its role as an abductor and possibly an extensor, and the broadened manubrium suggests an increase in the adductive power of the pectoralis major.

Thus it is clear that the dugong is better equipped than the manatees for fore-and-aft sweeping movements of the whole limb, including the scapula. This accords with its greater degree of overall specialization for swimming (Domning, 1977a: 28-30). Its limb proportions, however, are more comparable to those of $T$. senegalensis and $T$. manatus than $T$. inunguis, the humerus and radius respectively forming $36 \%$ and $24 \%$ of the forelimb length (measured from photograph of adult specimen in Kaiser, 1974: pl. 60); so it is also clear that not all the factors influencing the form of the sirenian flipper have yet been taken into account. The need for systematic cbservations on the behavior and locomotion of live sirenians, in both field and laboratory. remains as great as ever; without such data the questions posed by the anatomist will remain unanswered. 


\section{RESUMO}

Os músculos esqueléticos do peixe-boi da Amazônia (Trichechus inunguis) são descritos, ilustrados e comparados com prévias descrições dos sistemas musculares dos peixes-bois e do dugong. Mapas das ligaçöes dos músculos aos ossos, e dados sobre os pesos dos músculos da queixada, da nadadeira etc. são incluídos. Notam-se diferenças entre as espécies de peixes-bois com respeito aos músculos rectus capitis lateralis e biceps brachii, e também entre os peixes-bois e o dugong. Corrigem-se algumas interpretações errôneas na ćescrição (Domning, 1977) da miologia do Dugong. Descrevem-se o mecanismo de protrução das cerdas do lábio superior, e o mecanismo de abertura das narinas; estas são fechadas involuntariamente por tecido elástico. Análise com vetores dos músculos da queixada da Trichechus inunguis indica que os sirênios não podem ser colocados em nenhuma das categorias adaptivas demarcadas por Turnbull (1970). Ao contrário, eles constituem um grupo divergentamente especializado, que se caracteriza, em parte, por possuir um músculo temporalis muito grande e vantajosamente situado, constituindo mais que metade do peso dos músculos adutores, e por uma articulação entre o processo pterigoídeo e a mandíbula. Esta articulação serve, provavelmente, para apoiar a mandíbula na mastigação transversal. O centro de rotação da mandíbula na mastigação transversal parece ficar posteromedial ao processo pterigoideo no lado ativo; o temporalis do outro lado fornece a maioria da força necessária para esta rotação. Particularidades dos músculos e articulações do pescoço favorecem a hipótese que o $T$. inunguis é mais especializado do que o $T$. manatus para se alimentar perto da superfície da água. A nadadeira do $T$. inunguis é mais especializada para nadar do que a do $T$. manatus, mas não apresenta o grau de adaptação encontrado no Dugong, para movimentos parasagitais do ombro. 


\section{LITERATURE CITED}

BAHRDT, HUNS JOACHIM

1933 - Beiträge zur Entwicklungsgeschichte der Sirenenflosse. Jena. Zs. Naturw., 68(1) : 193-276.

BLESSING, MANFRED $\mathrm{H}$.

1972 - Studies on the concentration of myoglobin in the sea-cow and porpoise. Comp. Biochem. Physiol. A, Comp. Physiol., 41(3) : 475480

CUVIER, Georges

1890 - Sur l'ostéologie du lamantin, sur la place que le lamantin et le dugong doivent occuper dans la méthode naturelle, et sur les os fossiles de lamantins et de phoques. Ann. Mus. Hist, Nat., 13: 273312. PI. 19.

DOMNING, DARYL P.

1977a - Observations on the myology of Dugong dugon (Müller). Smithson. Contrib. Zool., $226: \mathrm{iii}+57$.

1977b - An ecological model for Late Tertiary sirenian evolution in the North Pacific Ocean. Syst. Zool., 25(4) : 352-362.

FrEUND, Ludwig

1930 - Beiträge zur Morphologie des Urogenitalsystems der Säugetiere. I. und II. Der weibliche Urogenitalapparat von Manatus, Zs. Wiss. Biol. Abt. A, Morph. Oekol. Tiere, $17(3): 417-440$.

GARROD, A.H.

1877 - Notes on the manatee (Manatus americanus) recently living in the Society's gardens. Trans. Zool. Soc. London, 10(3) : 137-145. Pls. 28-30.

GENSCHOW, JOACHIM

1934 - Ueber den Bau und die Entwicklung des Geruchsorganes der Sirenen. Zs. Wiss. Biol. Abt. A, Morph. Oekol, Tiere, 28(4) : 402444.

GINGERICH, PHILIP D.

1971 - Functional significance of mandibular translation in vertebrate jaw mechanics. Postilla, \#152: 1-10.

GUDERNATSCH, J.F.

1909 - Zur Anatomie und Histologie des Verdauungstraktes der Sirenia. II. Die Zunge von Manatus latirostris Harl. Morph. Jahrb., 40: 184-194. $1 \mathrm{pl}$.

HARTMAN, D.S.

1971 - Behavior and ecology of the Florida manatee, Trichechus manatus latirostris (Harlon), at
Crystal River, Citrus County. Ph. D. dissertation, Cornell Univ., Ithaca, New York, USA.

1974 - Distribution, status, and conservation of the manatee in the United State. Report filed with the National Fish and Wildlife Laboratory, Gainesville, Florida, USA.

HATT, ROBERT T.

1934 - A manatee collected by the American Museum Congo Expedition, with observations on the Recent manatees. Bull. Amer. Mus., Nat, Hist., 66(4) : 533-566. PI. 27.

Howell, AlFred Braziter

1930 - Aquatic mammals : Their adaptations to life in the water. Springfield, III., C. C. Thomas: $x i i+338$

KaISER, HaNS E.

1974 - Morphology of the Sirenia: A macroscopic and X-ray atlas of the osteology of Recent species. Basel, S. Karger : viii +76.64 pls.

KAY, R.F. \& HIIEMAE, K.M.

1974 - Jaw movement and tooth use in Recent and fossil primates. Am. J. Phys. Anthrop., $40: 227-256$

KAUDERN, WALTER

1917 — Studien über die männlichen Geschlechtsorgane von Sirenia, Hyracoidea, und Proboscidea. Zool. Jahrb., Abt. Anat., 40: 203-244.

Krauss, F.

1872 - Die Beckenknochen des surinamischen Manatus, Arch. Anat. Physiol. wiss. Med., 1872: 257-292. Pls. 9-10.

MURIE, JAMES

1872 - On the form and structure of the manatee (Manatus americanus). Trans, Zool. Soc. London, 8(3) : 127-202. Pls. 17-26.

1880 - Further observations on the manatee. Trans. Zool. Soc. London, 11(2): 19-48. Pls. 5-9.

OWEN, RICHARD

1838 - [On the anatomy of the dugong.] Proc. Zool. Soc. London, $6: 28-45$.

Pereira, MaNoel Nunes

1944 - O peixe-boi da Amazônia. Bol. Minist Agric. (Rio de Janeiro), 33(5): 21-95.

PETIT, G.

1925 - Recherches anatomiques sur l'appareil génito-urinaire male des Siréniens. Arch. Morph. Gen. Exper,, no. 23': iv + 326.

PETIT, G. \& Rochon-Duvigneaud, A.

1929 - L'oeil et la vision de l'Halicore dugong Erxl. Bull. Soc, Zool. France, 54(2): 129138. 
PÜTTER, AUgust

1902 - Die Augen der Wassersäugetiere. Zool Jahrb., Abt. Anat., 17(1/2): 99-402. Pls. 2-4.

QUIRING, D.P. \& HARLAN, C.F.

1953 - On the anatomy of the manatee. J. Mammal., $34(2)$ : 192-203.

RAPP, W.L. VON

1837 - Die Cetaceen zoclogisch-anatomisch dargestellt. Stuttgart \& Tübingen, J. P. Cotta : vi +182.8 pls.

ROBINEAU, DANIEL

1969 - Morphologie externe du complexe osseux temporal chez les Siréniens. Mém. Mus. Nat. Hist. Nat., Sér. A (Zool.), (2)60(1): $1-32$.

\section{SABAN, ROGER}

1975 - La musculature peaucière de la tête chez un jeune lamantin du Sénégal (Trichechus sєnegalenssi Link 1795; Mammifère, Sirénien). Zentralblatt Veter. Med., Reihe C, Anat. Histol. Embryol., 4(3) : 232-248.

SIMPSON, G.G.

1932 - Fossil Sirenia of Florida and the evolution of the Sirenia. Bull. Amer. Mus. Nat. Hist., 59(8) : 419-503.
SIOLI, HaRald

1958 - Principal biotopes of primary production in the waters of Amazonia. Proc. Symp. Recent Adv. Trop. Ecol., 591-600.

SLIJPER, E.J.

1946 - Comparative , biologic-anatomical investigations on the vertebral column and spinal musculature of mammals. Verh. K. Nederl. Akad. Wet., Afd. Natuurk., (2)42(5): 1-128.

Stannius, Hermann F.

1845 -- Beiträge zur Kenntniss der amerikanischen Manati's. Rostock, Adler's Erben: 1-37. 2 pls.

1849 - Beschreibung der Muskeln des Tümmlers (Delphinus phoceena). Müllers Arch. Anat., 1848: $1-41$.

TURNBULL, WILLIAM D.

1970 - Mammalian masticatory apparatus. Fieldiana (Geology), 18(2) : 147-356.

VOSSELER, J.

1924/5 - Pflege und Haliung der Seekühe (Trichechus) nebst Beiträge zu ihrer Biologi. Pallasia (Dresden), 2(2) : 58-67, 113-133, pls. 5-6 : 2(3): $167-180,213-230$.

VROLIK, WILLEM T.

1852 - Bijdrage tot de natuur- en ontleedkundige kennis van den Manatus Americanus. Bijdragen tot de Dierkunde, 1: 53-80, 6 pls.

(Aceito para publicaçäo em 19/05/78) 


\section{LIST OF ABBREVIATIONS}

\section{Muscles}

$\begin{array}{ll}\mathrm{AbD} & \text { ?Abductor digiti quinti } \\ \mathrm{ArT} & \text { Arytenoideus transversus } \\ \mathrm{Au} & \text { Sphincter colli profundus ?pars } \\ & \text { auris } \\ \mathrm{B} & \text { Biceps brachii } \\ \mathrm{Br} & \text { Brachialis } \\ \mathrm{Brc} & \text { Brachiocephalicus } \\ \mathrm{Brr} & \text { Brachioradialis } \\ \mathrm{Bu} & \text { Buccinatorius } \\ \mathrm{Bul} & \text { Bulbocavernosus } \\ \mathrm{Ch} & \text { Cephalohumeralis } \\ \mathrm{Cob} & \text { Ccracobrachialis } \\ \mathrm{CoVe} & \text { Constrictor vestibuli } \\ \mathrm{CoVu} & \text { Constrictor vulvae } \\ \mathrm{CrD} & \text { Cricoarytenoideus dorsalis } \\ \mathrm{CrL} & \text { Cricoarytenoideus lateralis } \\ \mathrm{Crp} & \text { Cricopharyngeus } \\ \mathrm{Crt} & \text { Cricothyroideus } \\ \mathrm{CuT} & \text { Cutaneus trunci } \\ \mathrm{D} & \text { Deltoideus } \\ \mathrm{Di} & \text { Digastricus } \\ \mathrm{ECR} & \text { Extensor carpi radialis } \\ \mathrm{ECU} & \text { Extensor carpi ulnaris } \\ \mathrm{EDC} & \text { Extensor digitorum communis } \\ \mathrm{EDQ} & \text { Extensor digiti quinti } \\ \mathrm{EP} & \text { Extensor pollicis (brevis et } \\ & \text { longus) } \\ \mathrm{FCR} & \text { Flexor carpi radialis } \\ \mathrm{FCU} & \text { Flexor carpi ulnaris } \\ \mathrm{FD} & \text { Flexor digitorum (superficialis et } \\ & \text { profundus) } \\ \mathrm{FDQ} & \text { ?Flexor digiti quinti brevis } \\ \mathrm{FP} & \text { ?Flexor pollicis brevis } \\ \mathrm{Fr} & \text { Frontalis } \\ \mathrm{Gr} & \text { Genioglossus } \\ \mathrm{Gh} & \text { Geniohyoideus } \\ \mathrm{He} & \text { Hyoepiglotticus } \\ \mathrm{Hg} & \text { Hyoglossus } \\ \mathrm{Hp} & \text { Hyopharyngeus } \\ \mathrm{IID} & \text { Iliocostalis dorsi } \\ \mathrm{Inc} & \text { Intercartilaginei externi } \\ \mathrm{Inf} & \text { Infraspinatus } \\ & \end{array}$

$\begin{array}{ll}\text { IntE } & \text { Intercostales externi } \\ \text { Intl } & \text { Intercostales interni } \\ \text { Into II-V } & \text { Interossei } \\ \text { Intr } & \text { Intertransversarius coccygeus } \\ \text { Isc } & \text { Ischiococcygeus } \\ \text { Iscv } & \text { Ischiocavernosus } \\ \text { IU } & \text { Ischiourethralis } \\ \text { LaD } & \text { Latissimus dorsi } \\ \text { LaN } & \text { Lateralis nasi } \\ \text { LeC } & \text { Levatores costarum } \\ \text { LeN } & \text { Levator nasolabialis } \\ \text { LnD } & \text { Longissimus dorsi } \\ \text { LoCa } & \text { Longus capitis } \\ \text { LoCo }{ }^{-3} & \text { Longus colli } \\ \text { LP } & \text { Levator penis } \\ \text { Lu III-V } & \text { Lumbricales } \\ \text { M } & \text { Masseter } \\ \text { Mn } & \text { Mandibularis } \\ \text { Mnl } & \text { Maxillonasolabialis } \\ \text { Mt } & \text { Mentalis } \\ \text { My } & \text { Mylohyoideus } \\ \text { OAE } & \text { Obliquus abdominis externus } \\ \text { OAI } & \text { Obliquus abdominis internus } \\ \text { OCa } & \text { Obliquus capitis caudalis } \\ \text { OCr } & \text { Cbliquus capitis cranialis } \\ \text { OD } & \text { Obliquus dorsalis } \\ \text { OOc } & \text { Orbicularis oculi } \\ \text { OOr } & \text { Orbicularis oris } \\ \text { OV } & \text { Obliquus ventralis } \\ \text { Pap } & \text { Palatopharyngeus } \\ \text { PIJ } & \text { Platysma pars jugularis } \\ \text { PMa } & \text { Pectoralis major } \\ \text { PMi } & \text { Pectoralis minor } \\ \text { PtE } & \text { Pterygoideus externus } \\ \text { Ptl } & \text { Pterygoideus internus } \\ \text { Ptp } & \text { Pterygopharyngeus } \\ \text { RA } & \text { Rectus abdominis } \\ \text { RB } & \text { Retractor bulbi } \\ \text { RCl } & \text { Rectus capitis dorsalis } \\ & \text { mediuster- } \\ \text { RCMi } & \text { Rectus capitis dorsalis minor } \\ \text { RCV } & \text { Rectus capitis ventralis } \\ \text { RD } & \text { Rectus dorsalis } \\ \text { Rel } & \text { Retractor ischii } \\ & \end{array}$




\begin{tabular}{|c|c|c|c|}
\hline Rh & Rhomboideus & buv & bulbus vestibull \\
\hline RL & Rectus capitis lateralis & bv & blood vessels \\
\hline RLa & Rectus lateralis & bv (if) & biood vessels passing through \\
\hline RM & Rectus medialis & & infraorbital foramen \\
\hline RV & Rectus ventralis & $b v+n$ & blood vessels and nerves \\
\hline Sc & Scalenus & $\mathrm{c}_{1^{-6}}$ & cervical vertebrae \\
\hline SCPO & Sphincter colli profundus pars oris & car & carotid artery \\
\hline Se & Semispinalis & $\mathrm{cc}$ & coronoid canal \\
\hline $\mathrm{SeC}$ & Semispinalis capitis & $\mathrm{ch}$ & chevron bone \\
\hline SeM & Serratus magnus & $\mathrm{cp}$ & crus penis \\
\hline SpA & Sphincter ani & cr & cricoid cartilage \\
\hline $\mathrm{SpC}$ & Sphincter colli superficialis & dc & dental capsule \\
\hline Spl & Splenius & e & epihyoid \\
\hline St & Stapedius & eam & external auditory meatus \\
\hline Stc & Sternocostalis & ejv & external jugular vein \\
\hline Sth & Sternohyoideus & en & external nares \\
\hline Stm & Sternomastoideus & eo & exoccipital \\
\hline Stt & Sternothyroideus & es & esophagus \\
\hline Styg 1,3 & Styloglossus & et & ethmoturbinal \\
\hline Styh & Stylohyoideus & eu & eustachian aube \\
\hline Styp & Stylopharyngeus & $f$ & frontal \\
\hline Su & Subscapularis & $\mathrm{fm}$ & foramen magnum \\
\hline Sup & Supraspinatus & $\mathrm{g}$ & glenoid facet (temporal condyle) \\
\hline SVL & Sacrococcygeus ventralis lateralis & $\mathrm{h}$ & humerus \\
\hline SVM & Sacrococcygeus ventralis medialis & $\mathbf{i}$ & incus \\
\hline $\mathrm{T}$ & Temporalis & icl & ischiococcygeal ligament \\
\hline Ter & Teres major & $\mathrm{ijv}$ & internal jugular vein \\
\hline $\mathrm{TeV}$ & Tensor veli palatini & is & ischium \\
\hline Tha & Thyroarytenoideus & j & jugal \\
\hline Thh & ?Thyrohyoideus & $\mathrm{k}$ & keratohyoid \\
\hline ThhM & Thyrohyoideus minor & $\lg$ & deep cervical lymph nodes \\
\hline Thp & Thyropharyngeus & $\mathrm{m}$ & mandible \\
\hline $\operatorname{TrA}$ & Transversus abdominis & mdf & mandibular foramen \\
\hline TrLa & Triceps brachii, lateral head & $\mathrm{mf}$ & mental foramina \\
\hline TrLo & Triceps brachii, long head & $\mathrm{ml}$ & malleus \\
\hline TrM & Triceps brachii, medial head & $\mathrm{mx}$ & maxilla \\
\hline Trp & Trapezius & $\mathrm{nc}$ & nasal cartilage \\
\hline $\mathrm{TT}$ & Tensor tympani & np & narial passage \\
\hline$U$ & Urethralis & $\mathrm{nph}$ & nasal pharynx \\
\hline $\mathrm{Ve}$ & ?Ventricularis & occ & occipital condyle \\
\hline Vo & ?Vocalis & on & optic nerve \\
\hline \multirow[t]{3}{*}{$z$} & Zygomaticomandibularis & oph & oral pharynx \\
\hline & & $\mathrm{p}$ & periotic \\
\hline & Other Structures & pa & parietal \\
\hline a & anus & pal & palatine \\
\hline af & antebrachial fascia & pe & penis \\
\hline ar & arytenoid cartilage & $\mathrm{pg}$ & parotid gland \\
\hline as & alisphenoid & $\mathrm{ph}$ & pharynx \\
\hline $\mathrm{b}$ & basihyold & $\mathrm{pm}$ & premaxilla \\
\hline bo & basioccipital & po & preputial orifice \\
\hline bs & basisphenold & & presphenoid \\
\hline
\end{tabular}




$\begin{array}{llll}\mathrm{pt} & \text { pterygoid } & \mathrm{sq} & \text { squamosal } \\ \mathrm{pt}_{1} & \text { postthoracic vertebra } 1 & \mathrm{sr} & \text { sigmoid ridge of squamosal } \\ \mathrm{r} & \text { radius } & \mathrm{st} & \text { sternum } \\ \mathrm{r}_{1-15} & \text { ribs } & \mathrm{t} & \text { thyrohyoid } \\ \mathrm{rc} & \text { costal cartilage } & \mathrm{t}_{1-15} & \text { thoracic vertebrae } \\ \mathrm{re} & \text { rectum } & \mathrm{th} & \text { thyroid cartilage } \\ \mathrm{s} & \text { symphysis of mandible } & \mathrm{tm} & \text { tympanic membrane } \\ \mathrm{sc} & \text { scapula } & \text { to } & \text { tcngue } \\ \mathrm{scc} & \text { scapular cartilage } & \mathrm{tr} & \text { trachea } \\ \mathrm{scv} & \text { subclavian vein } & \text { ty } & \text { tympanic } \\ \text { sh } & \text { stylohyoid } & \mathrm{u} & \text { ulna } \\ \mathrm{smg} & \text { submaxillary salivary gland } & \mathrm{ut} & \text { uterus } \\ \text { so } & \text { supraoccipital } & \mathrm{v} & \text { vulva } \\ \mathrm{sp} & \text { stapes } & \mathrm{vo} & \text { vomer }\end{array}$




\section{INDEX}

Valid names of muscles and page of primary description are shown in italics. A list of the figures in which each muscle appears is found with the primary description. Names of muscles which are illustrated are followed in the index by the abbreviations used in the figures.

?Abductor digiti quinti (AbD), ...46,47, 67 Abductor minimi digiti, ............ 47 ?Abductor pollicis longus, ........45, 56 Accelerator urinae, ................ 52 Adductor pollicis, ............... 47 Anconeus, .................... 43 Aryepiglotticus, $\ldots \ldots \ldots \ldots \ldots . \ldots 24,25,56$ Aryteno-epiglottideus, . . . . . . . . . . . 25 Arytenoideus transversus (ArT), . ...... 25 Auriculares, .................. 8, 55 Auricularis - see Platysma pars auricularis Auris - see Sphincter colli profundus

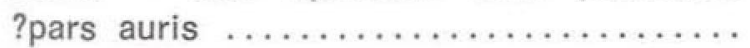
Biceps brachii (B) , ...... 39, 42, 54, 67, 70 Biventer cervicis, ................. 27 Brachialis $(\mathrm{Br}), \ldots \ldots \ldots .38,39,42,43,67$ Brachialis anticus, .............. 43 Brachiocephalicus (Brc), ... 29, 37-38, 3943 Brachioradialis (Brr) , .......44, 44, 45, 67 Buccalis - see Buccinatorius pars buccalis; Platysma pars buccalis ............... Buccinator pars mentalis, ......... 12, 14 Buccinator pars orbicularis oris, ....... 12 Buccinatorius $(\mathrm{Bu}), \ldots \ldots \ldots \ldots \ldots \ldots .12,14$ Buccinatorius pars buccalis or maxillomandibularis, ................ 12 Buccinatorius pars molaris or longitudinalis, 12 Bulbocavernosus (Bul) , ......... 52, 53 Cephalo-humeral, ................ 37 Cephalohumeralis. (Ch), .... 10, 29, 37, 38 Cervicalis ascendens, .............. 27

Choanoid, ...................... 18 Complexus, .................. 25, 27 Compressor nasi, .................. 14

Constrictor medius, ................ 24

Constrictor superior, $\ldots \ldots \ldots \ldots \ldots \ldots, 22$
Constrictor vestibuli $(\mathrm{CoVe}), \ldots .50,52,56$ Constrictor vulvae $(\mathrm{CoVu}), \ldots \ldots \ldots .50,52$ Coracobrachialis (Cob), .. 38, 42, 43, 54, 67 Cricoarytenoideus dorsalis ( $\mathrm{CrD}), \ldots .22,24$ Cricoarytenoideus lateralis $(\mathrm{CrL}), \ldots \ldots .24$ Cricopharyngeus (Crp), .......... 22, 24 Cricothyroideus (Crt) $, \ldots \ldots \ldots .22,24,29$ Cutaneus trunci (CuT), 8, 34, 35, 36, 38, 48, 50, $53,55,67,71$ Deltoideus (D), 29, 37, 38, 39, 43, 55, 67, 71 Depressor anguli oris, ........... 12, 14 Depressor labii inferioris, ............ 14 Depressor labii superioris alaeque nasi, .. 14 Diaphragm, ................... 34, 67 Digastricus (Di) , ............ 17, 18, 58 Dilatator naris, ................... 14

Dilatator nasi, ................... 14

Erector clitoridis, ................ 50 Erector penis, .................. 52 Extensor carpi radialis (ECR), . . 44, 45, 67 Extensor carpi ulnaris (ECU), .. $43444-45,67$ Extensor digiti quinti (EDQ), ......44,67 Extensor digitorum communis (EDC), 44, 45, 67 Extensor minimi digiti, ............. 44 Extensor pollicis brevis et longus (EP), 44, 45, $55,56,67$

Extensores primi and secundi internodii pollicis, ................... 45, 56 Extensor radialis longus et brevis, ..... 44 Flexor brevis minimi digiti, ...... 46, 47 Flexor brevis pollicis, ............. 47 Flexor carpi radialis (FCR), .... 43, 45, 67 Flexor carpi ulnaris (FCU), 45, 46, 47, 56, 67 ?Flexor digiti quinti brevis (FDQ), .. 47, 67 Flexor digitorum (superficialis et profundus) (FD) , .......... 45, 46, 47, 67 Flexor digitorum profundus, . . . . . . 55 Flexor digitorum superficialis, ......... 55 Flexor haemalis, .............. 36, 55 ?Flexor pollicis brevis (FP), ...... 47, 67 Flexor pollicis longus, $\ldots \ldots \ldots \ldots \ldots \ldots, 46$ Flexor profundus, $\ldots \ldots \ldots \ldots \ldots \ldots \ldots, 46$ Flexor sublimis, $\ldots \ldots \ldots \ldots \ldots \ldots \ldots \ldots, 46$ Frontalis $(\mathrm{Fr}), \ldots \ldots \ldots \ldots \ldots \ldots \ldots \ldots$ 
Genioglossus $(\mathrm{Gg}), \ldots \ldots \ldots \ldots \ldots \ldots 18,22$

Genio-hyo-glossus, ................ 18

Geniohyoideus (Gh) $, \ldots \ldots \ldots .18,20,22,67$

Hyoepiglotticus $(\mathrm{He}), \ldots \ldots \ldots \ldots \ldots 25$

Hyoepiglottideus, $\ldots \ldots \ldots \ldots \ldots \ldots \ldots 25$

Hyoglossus $(\mathrm{Hg}), \ldots \ldots \ldots \ldots \ldots . \ldots 18,2022$

Hyopharyngeus $(\mathrm{Hp}), \ldots \ldots \ldots \ldots \ldots, 22$

llio-coccygeus, .............. 48, 50

Iliocostalis dorsi (IID), ... 27-28, 35, 36, 67

Ilio-costalis lumborum, . . . . . . . . . 28

lliocostalis thoracis, $\ldots \ldots \ldots \ldots \ldots \ldots 28$

Infracoccygeus, ................. 36

Infraspinatus (Inf), ... 37, 39, 42, 55, 67, 70

Intercartilaginei externi (Inc), ... 33, 34, 67

Intercostales externi (IntE), ... 31, 33, 37, 67

Intercostales interni (Int|), ..... 33, 35, 67

Intermedia - see Sphincter colli profundus

pars intermedia

Interossei (Into II-V) , ........47, 48, 67

Intertransversarius caudae dorsalis, . . . 35

Intertransversarius coccygeus (Intr), 28,

$35-36,55,67$

Ischio-caudalis, $\ldots \ldots \ldots \ldots \ldots \ldots \ldots . \ldots 50$

Ischiocavernosus (Iscv) $, \ldots \ldots \ldots \ldots, 50,52$

Ischiococcygeus (Isc) , .......48, 50, 52

Ischiourethralis (lu) $\ldots \ldots \ldots \ldots \ldots \ldots, 52$

Jugularis - see Platysma pars jugularis

Jugulohyoideus, $\ldots \ldots \ldots \ldots \ldots \ldots \ldots \ldots 22$

Keratohyoideus, .................. 20

Lateralis nasi (LaN), ...... 12, 14, 56, 57

Latissimus dorsi (LaD), 38, 42, 43, 55, 67, 71

Levator anguli oris, ................ 14

Levator ani, ................... 34, 50

Levator caudae externus, ........ 27, 35

Levator cadae internus, $\ldots \ldots \ldots \ldots .27,35$

Levator claviculae, ............... 37

Levator labii inferioris, ............. 14

Levator labii superioris alaeque nasi, .... 10

Levator labii superioris proprius, ....... 14

Levator nasolabialis (LeN), ......10, 12, 14

Levator palati. .................... 24

Levator palpebrae, ................. 18

Levator penis (LP), .......... 50, 52-53

Lavator penis accessorius, .......... 52

Levator recti, ................... 50

Levator veli palatini, ................ 24

Levatores costarum (LeC), ........... 31

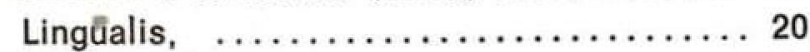

Longissimus capitis, ............ 27, 68

Longissimus dorsi (LnD), ... 25, 27, 28, 67
Longitudinalis - see Buccinatorius pars molaris

Longus capitis (LoCa), ........ 29, 31, 67

Longus colli $\left(\mathrm{LoCo}_{1-3}\right), \ldots \ldots \ldots \ldots . . . \ldots 1,67$

Lumbo-caudalis, .................. 35

Lumbricales (Lulll-V), .......... 47-48, 67

Mandibularis $(\mathrm{Mn}), \ldots \ldots \ldots \ldots \ldots 12,14,67$

Masseter (M), 16, 58, 60, 61, 62, 65, 66, 67

Maxillolabialis, .................. 14

Maxillo-mandibularis - see Buccinatorius

pars buccalis

Maxillonasolabialis (Mnl), ........ 14, 57

Mentalis (Mt), .............12, 14, 16, 67

Molaris - see Buccinatorius pars molaris

Multifidus, ...................... 25

Mylohyoldeus (My), ........... 18, 2022

Naso-labialis, ..................... 10

Naso-labialis superficialis, ........... 14

Naso-labialis profundus, ............ 14

Obliquus abdominis externus (OAE) 29,

$34-35,67$

Obliquus abdominis internus (OAI), 33, 35, 67

Obliquus capitis caudalis $(\mathrm{OCa}), \ldots \ldots 29$

Obliquus capitis cranialis $(\mathrm{OCr}), \ldots \ldots 28,29$

Obliquus dorsalis (OD) $, \ldots \ldots \ldots \ldots .17,18$

Obliquus inferior, ................ 29

Obliquus superior, ................ 29

Obliquus ventralis (OV), ............ 17

Omohyoideus, ..................... 20

Opponens minimi digiti, ............47

Oris - see Sphincter colli profundus

pars oris

Orbicularis oculi $(\mathrm{OO}), \ldots \ldots \ldots \ldots \ldots 10$

Orbicularis oris (OOr), .......... 12, 56

Orbicularis palpebrarum, $\ldots \ldots \ldots \ldots \ldots 10$

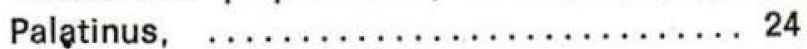

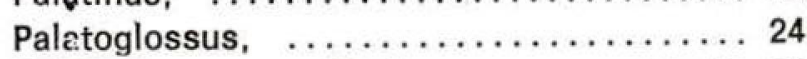

Palatopharyngeus (Pap), .......24, 25, 56

Palmaris longus, ....... 45-46, 47, 56, 67

Palpebralis - see Sphincter colli profundus

pars palpebralis

Panniculus carnosus, $\ldots \ldots \ldots \ldots .8,12,34$

Pectoralis major (PMa), 10, 29, 34, 38, 42, 43,

67,71

Pectoralis minor (PMi) , ..... 38, 55, 67, 71

Platysma pars auricularis, .......... 8

Platysma pars buccalis, ........... 8

Platysma pars jugularis (PIJ), . 8, 12, 34, 67

Platysma pars scapularis, $\ldots \ldots \ldots \ldots 8,55,70$

Platysma pars temporalis, ........... 8

Platysma pars zygomatica, ........... 8 
Platysma myoides, ............... 8

Pronator radii teres, .............. 45

Pronator teres. .................. 45

Pterygoideus externus (PtE), 16, 58, 59, 60, 61 . $62,65,66,67$

Pterygoideus internus (PtI), 17, 58, 59, 6061 , $62,63,65,66,67$

Pterygopharyngeus (Ptp), ........... 22

Pyramidalis nasi, ................ 10, 14

Quadratus lumborum, ............... 36

Rectus abdominis (RA), ......35, 38, 48, 67

Rectus capitis anticus major, ......... 31

Rectus capitis anticus minor, . ........ 29

Rectus capitis dorsalis ?intermedius ( $\mathrm{RCI})$,

$28,67,68$

Rectus capitis dorsalis ?major, ..... 28, 55

Rectus capitis dorsalis minor (RCMi),

$28,67,68$

Rectus capitis lateralis (RL), 27, 28, 29, 54

67,68

Rectus capitis posticus major, $\ldots \ldots \ldots 28$

Rectus capitis posticus minor, ........ 28

Rectus capitis ventralis (RCV), . 29, 55, 67

Rectus dorsalis (RD) , ............. 18

Rectus lateralis (of eye) (RLa), .... 17, 18

Rectus lateralis (of neck), .......... 28

Rectus medialis (RM) , ............. 18

Rectus ventralis (RV) , .......... 17, 18

"Rétracteurs du fourreau", ........... 53

Retractor bulbi (RB) , ............... 18

Retractor ischii (Rel) , ........ 50, 52, 53

Retractor labiorum, ............. 14, 55

Retractor penis, ............. 52, 53

Retractor penis accessorius, ........ 52

Rhomboideus (Rh) , .......... 37, 67, 70

Sacrococcygei dorsales lateralis et medi-

alis ............................. 35

Sacro-coccygeus, ................ 36

Sacrococcygeus ventralis lateralis (SVL), 34,

$35,36,50,67$

Sacrococcygeus ventralis medialis (SVM), 34 $35,36,55,67$

Sacro-lumbalis, $\ldots \ldots \ldots \ldots \ldots \ldots \ldots, 27,36$

Scalenus (Sc) $, \ldots \ldots \ldots 29,31,37,50,67$

Scalenus anticus, ................ 31

Scalenus posticus, ................ 31

Scapularis - see Platysma pars scapularis

Semispinalis" (Se) $, \ldots \ldots \ldots \ldots \ldots 25,27,67$

Semispinalis capitis ( $\mathrm{SeC}), 25,27,28,37,54$.

$67,68,69$
Serratus magnus (SeM), 29, 31, 37, 39, 55,

67,70

Sphincter ani (SpA), .......... 50, 52

Sphincter colli profundus ?pars auris (Au), $8-10,34,38,67$

Sphincter colli profundus pars intermedia, 10

Sphincter colli profundus pars intermedia

ventralis, ..................... 8

Sphincter colli profundus pars oris (SCPO),

$12,14,56$

Sphincter colli profundus pars palpebralis,

$8,10,55$

Sphincter colli superficialis (SpC), 8, 10, 12

Sphincter vaginae. ................ 50

Spinalis ....................... 27

Spinalis dorsi, ................ 27

Splenius (Spl), ........25, 37, 67, 6869

Stapedius (St) $\ldots \ldots \ldots \ldots \ldots \ldots \ldots 17$

Sternocostalis (Stc) $, \ldots \ldots \ldots \ldots 34,38,67$

Sternohyoideus (Sth) , ........ 20, 29, 67

Sternomastoideus (Stm), .... 10, 29, 37, 38

Sternothyroideus (Stt), .. 20, 22, 24, 29, 67

Styloglossus $\left(\right.$ Styg $\left._{1,3}\right), \ldots \ldots \ldots \ldots \ldots \ldots 18$

Stylohyoideus (Styh) , ............... 22

Stylopharyngeus (Styp) , ..............22

Subscapularis $(\mathrm{Su}), \ldots \ldots \ldots \ldots$ 39, 42, 67

Superciliaris, ................... 10

Supinator longus, ............... 43

Supraspinatus (Sup), ...... 38, 39, 67, 70

Temporalis (T), $10,16,56,58,60,61,62,63$,

65,67

Temporalis - see Platysma pars temporalis

Tensor palati, ................... 22

Tensor tympani (TT), .............. 17

Tensor veli palatini $(\mathrm{TeV}), \ldots \ldots \ldots .22,24$

Teres major (Ter), 38, 39, 42, 43, 55, 67, 71

Teres minor,$\ldots \ldots \ldots \ldots \ldots \ldots \ldots \ldots . \ldots 2$

Thyreoideus transversus, ............ 22

Thyroarytenoideus (Tha) , ............ 24

Thyroepiglotticus, ................. 25

Thyroepiglottideus, ................ 25

?Thyrohyoideus (Thh) , .... 20, 22, 29, 67

Thyrohyoideus minor (ThhM), ........20

Thyropharyngeus (Thp) , .......20, 22, 24

Trachelo-mastoid, ................ 27

Transversalis, .................... 35

Transversalis colli, . ................ 27

Transversarius, ............... 35, 36

Transversospinalis, ................ 25

Transversus abdominis (TrA), ..... 35, 67

Transversus perinaei, ............. 50 
Trapezius (Trp) , ... 36-37, 38, 39, 55, 67, 70 Triceps brachii, lateral head (TrLa), 43, 44

67,70

Triceps brachii, long head (TrLo), 43, 67, 70 Triceps brachii, medial head (TrM), 43, 44, 45

67,70

Urethralis (U), ............. 50, 52, 56

Uvulae,

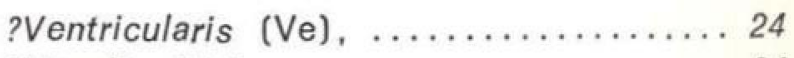

?Vocalis (Vo) , ....................... 24

"Würmformiger Muskel", ........... 52 Zygomatica - see Platysma pars Zygomatica Zygcmatico-labialis, .............. 8 Zygomaticomandibularis (Z), 16, 56, 58, 60 , $61,62,65,66,67$

Zygomaticus, $\ldots \ldots \ldots \ldots \ldots \ldots \ldots \ldots \ldots \ldots$ 


\section{APPENDIX}

The numeral at the bottom (or right hand side) of each panel denotes the figure number. The meanings of the abbreviations used on each panel are as indicated in the text of the monograph. 

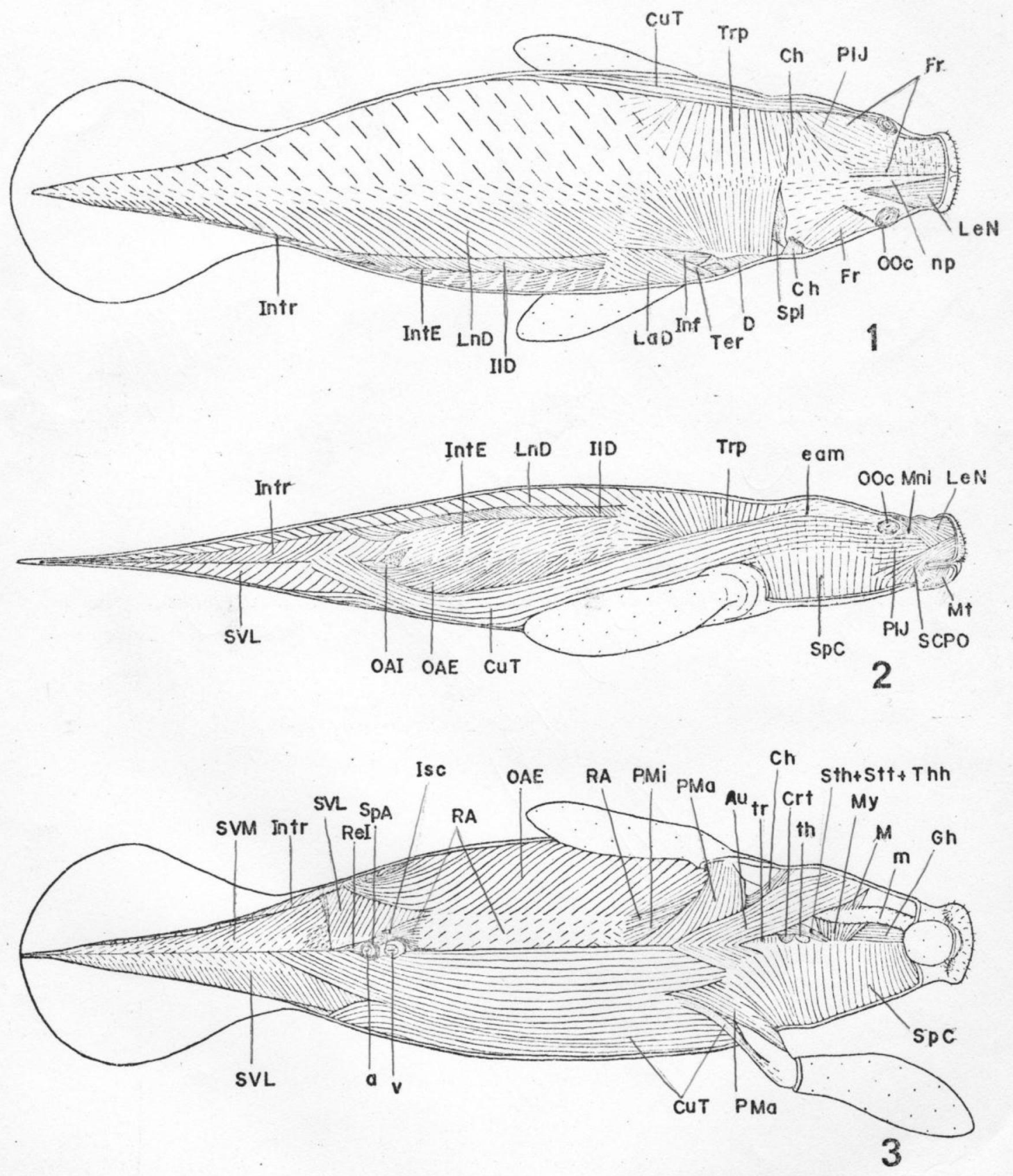


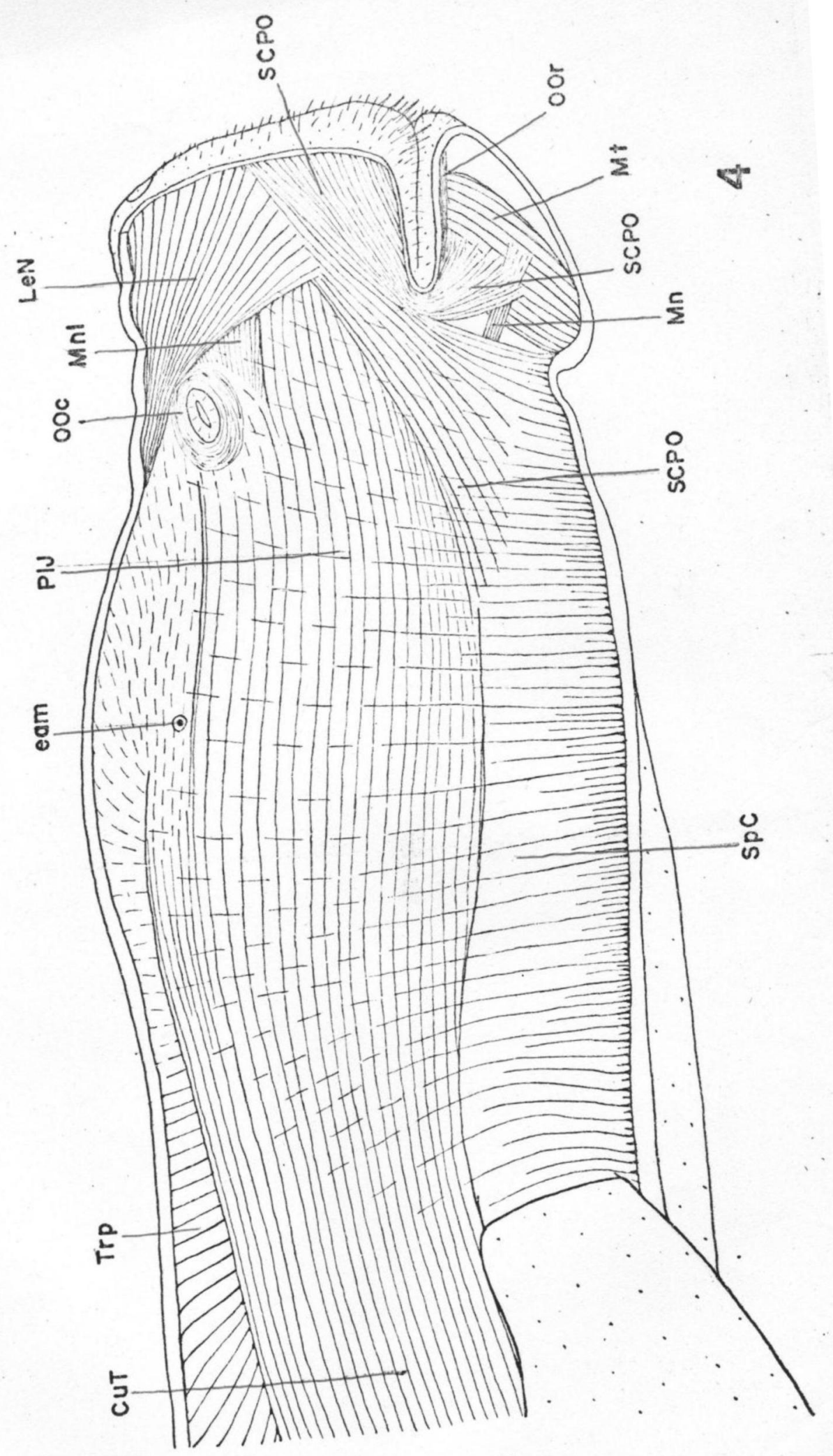




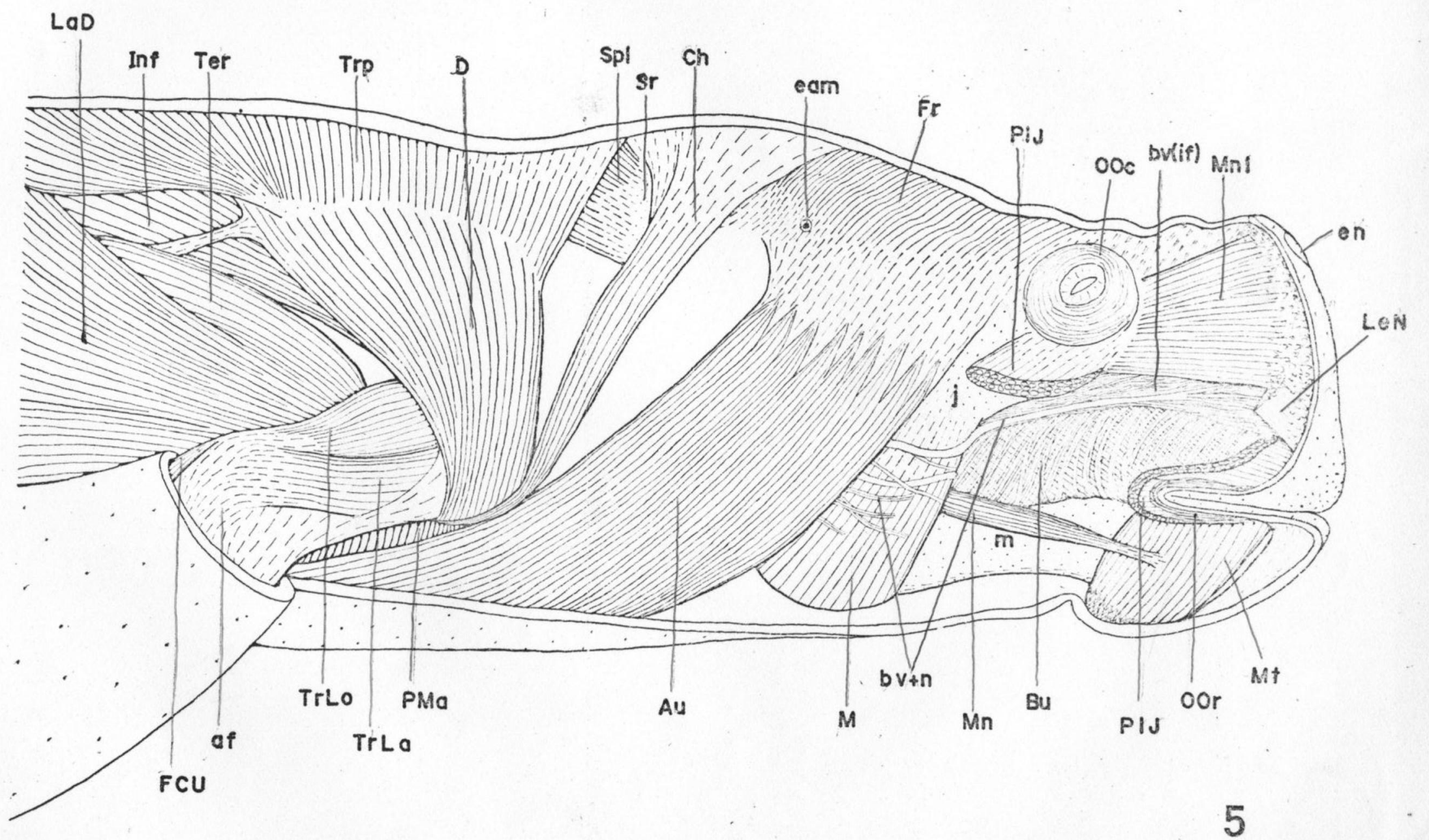




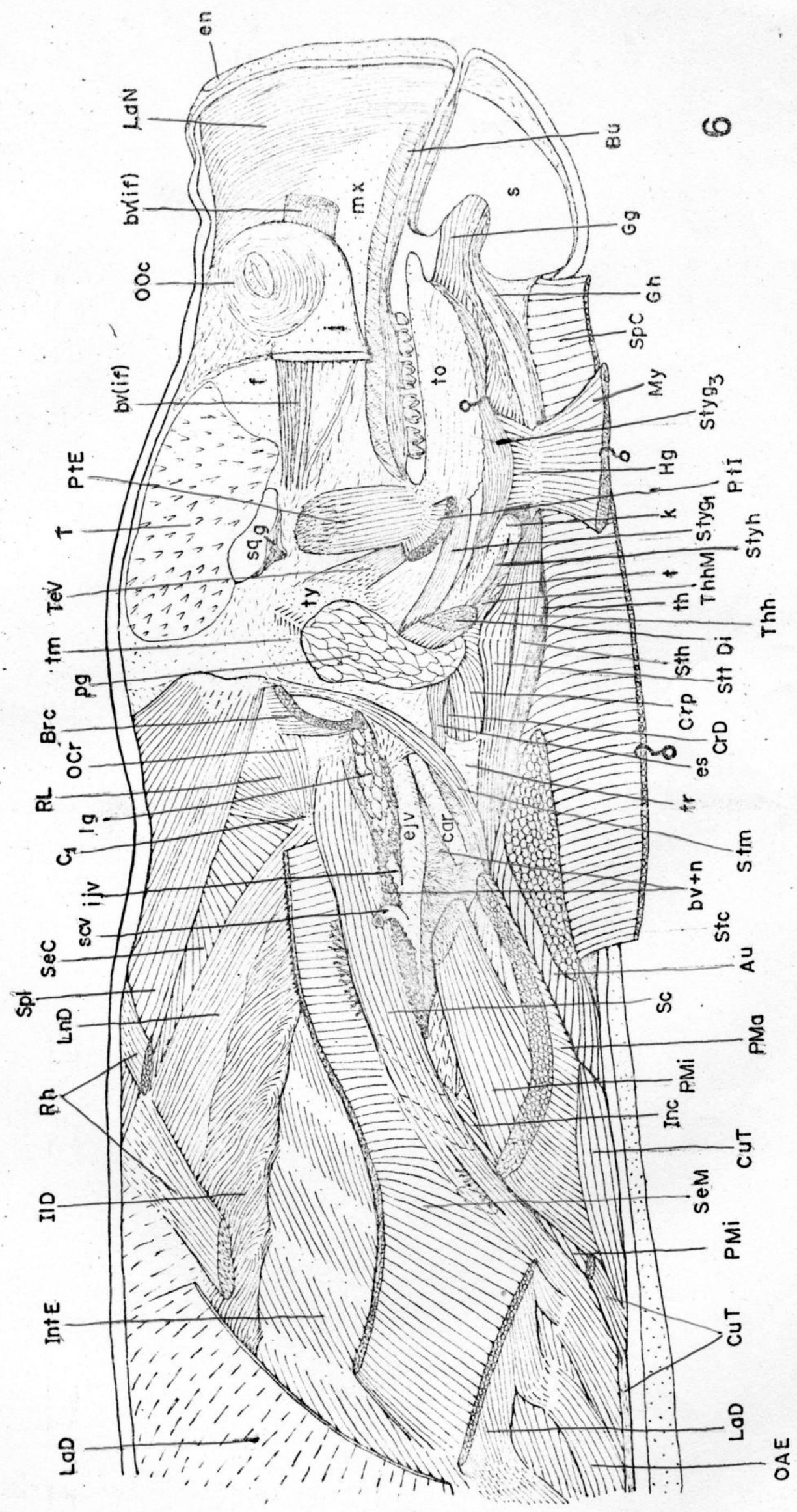




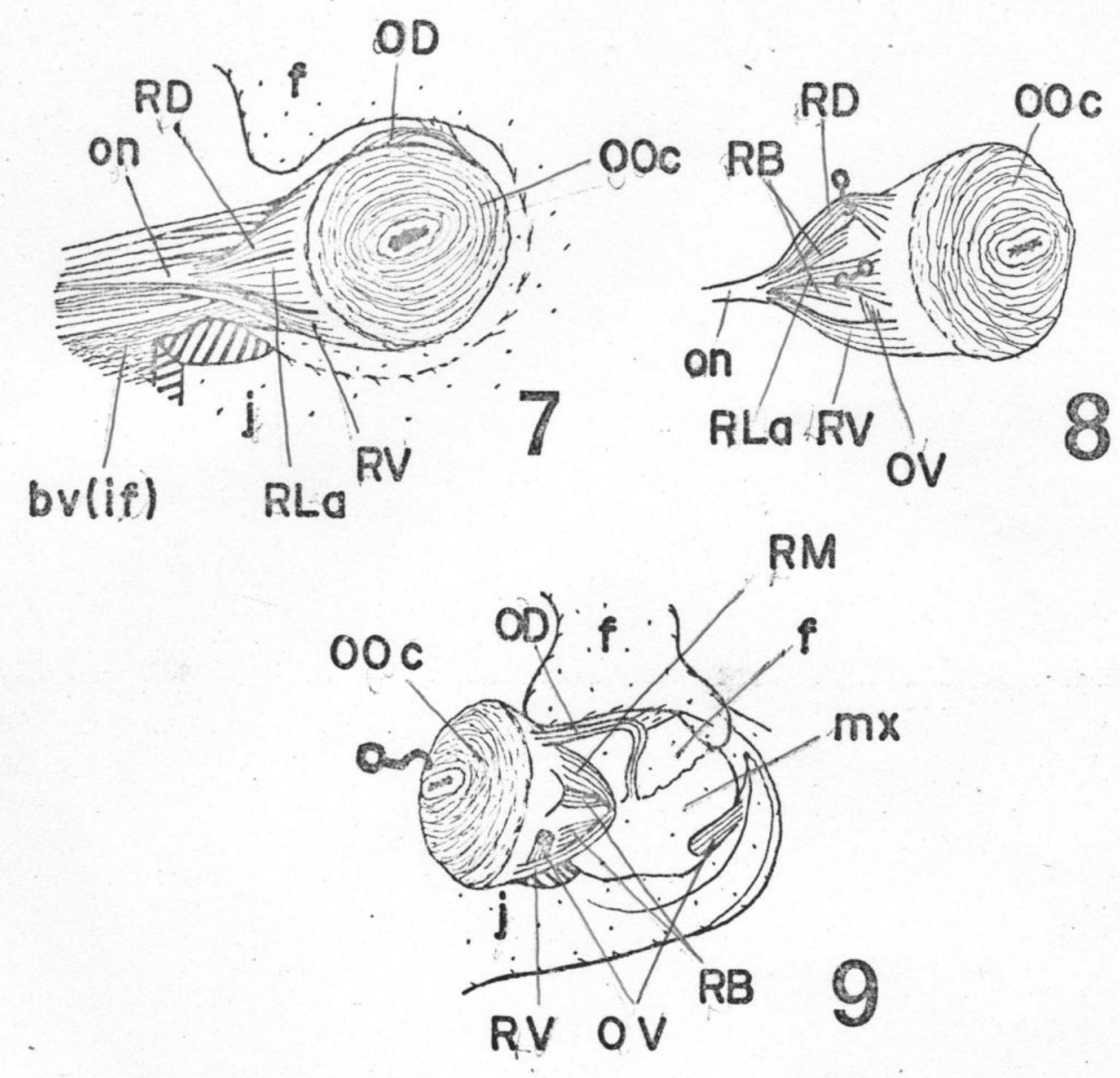




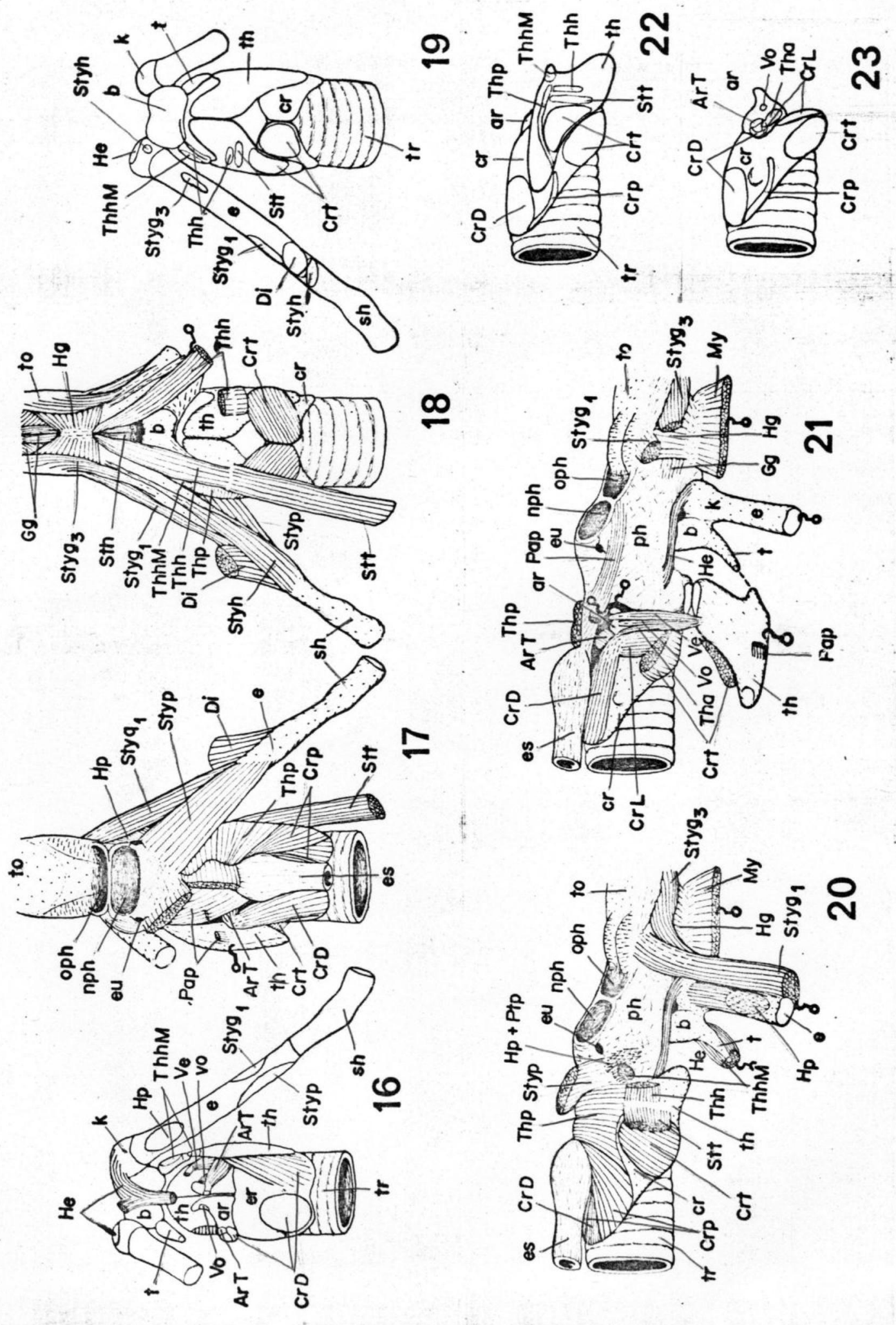




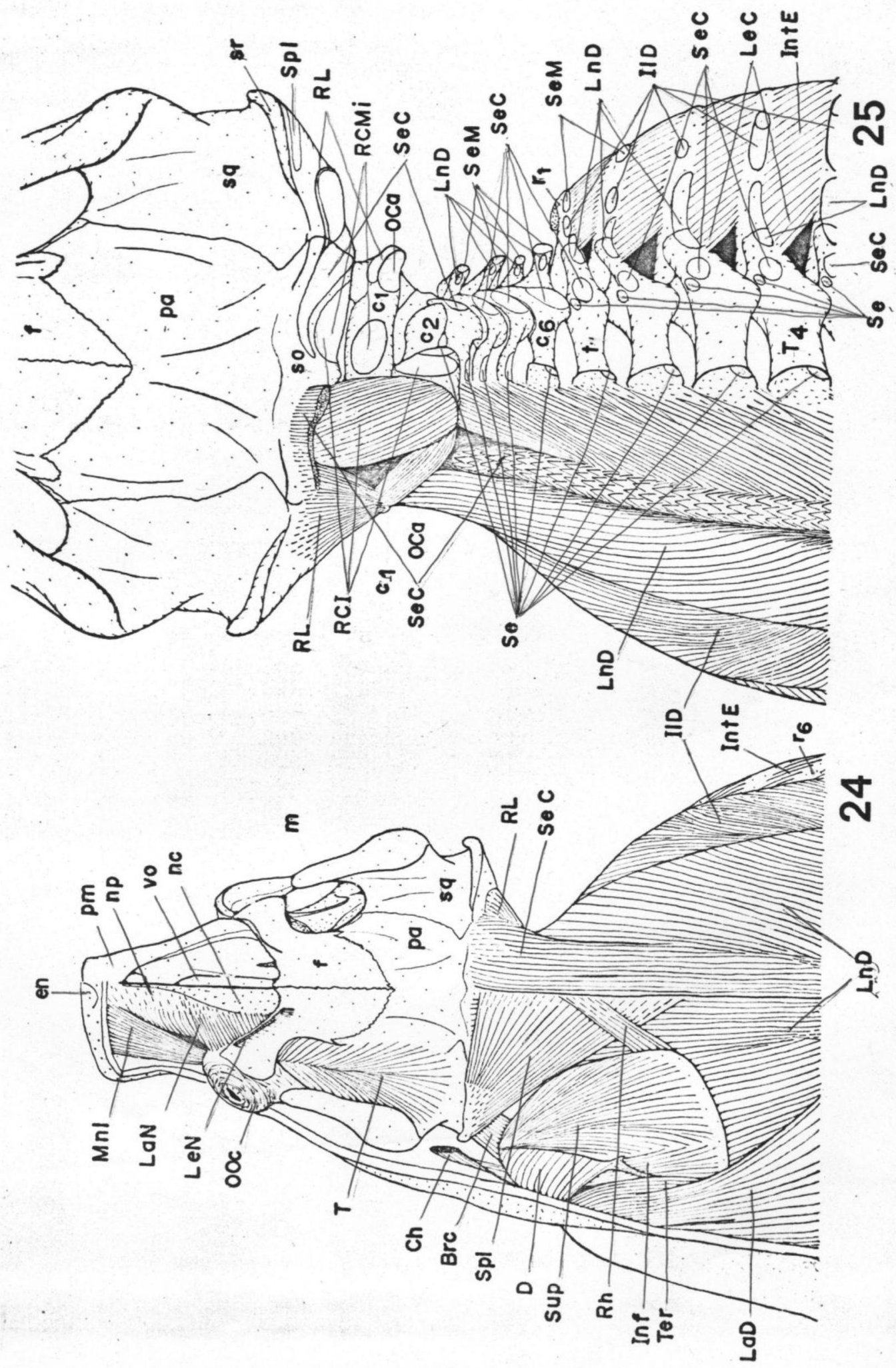




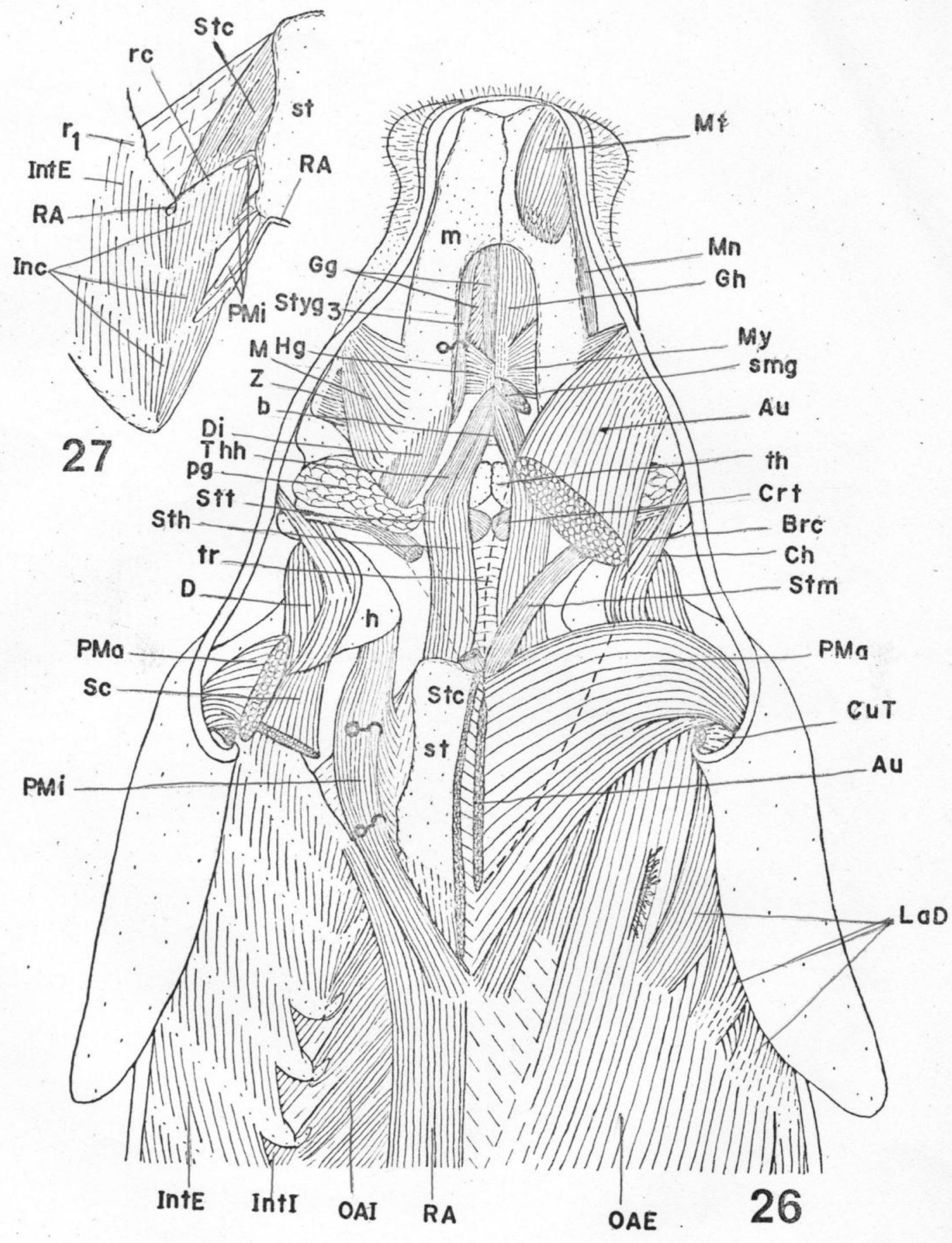




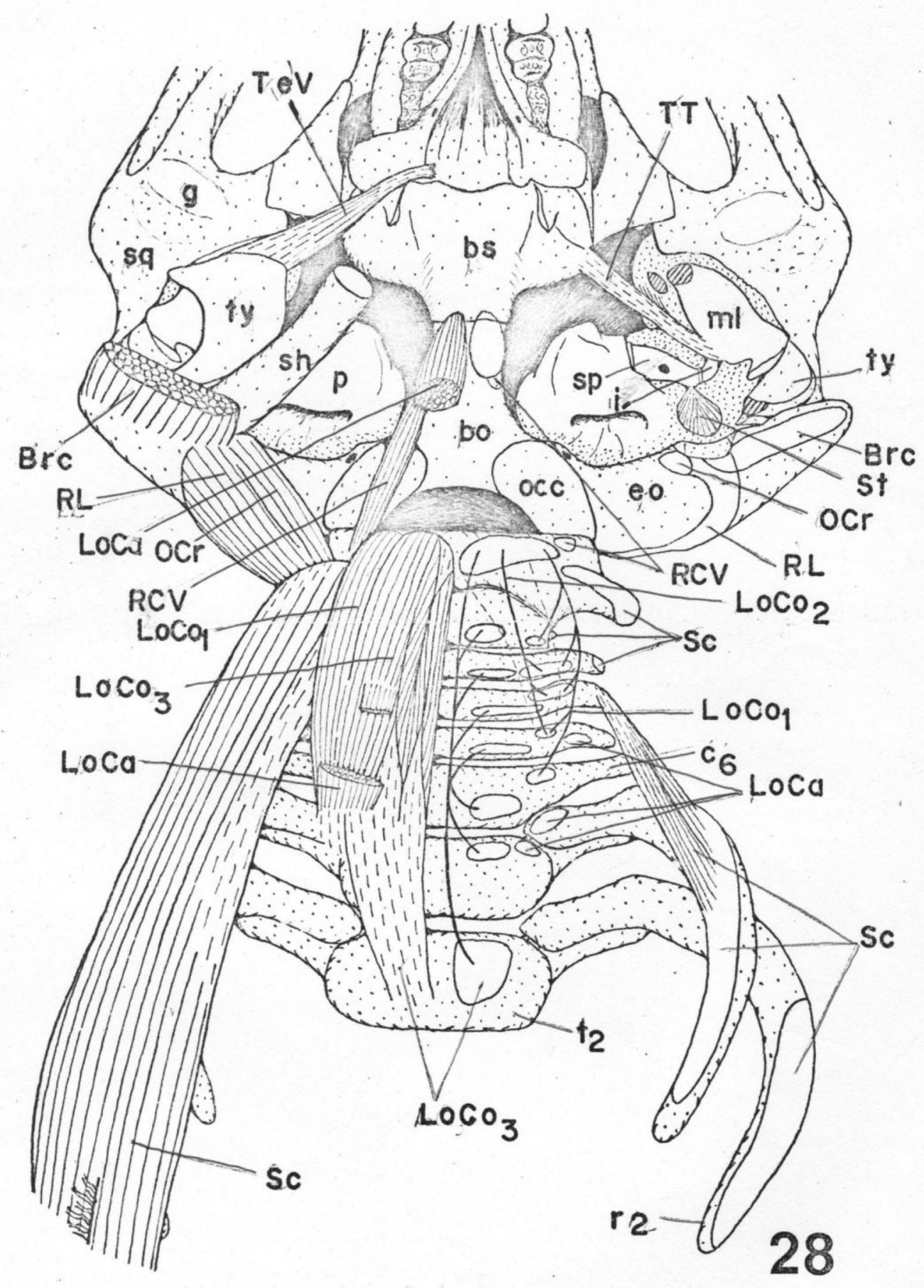




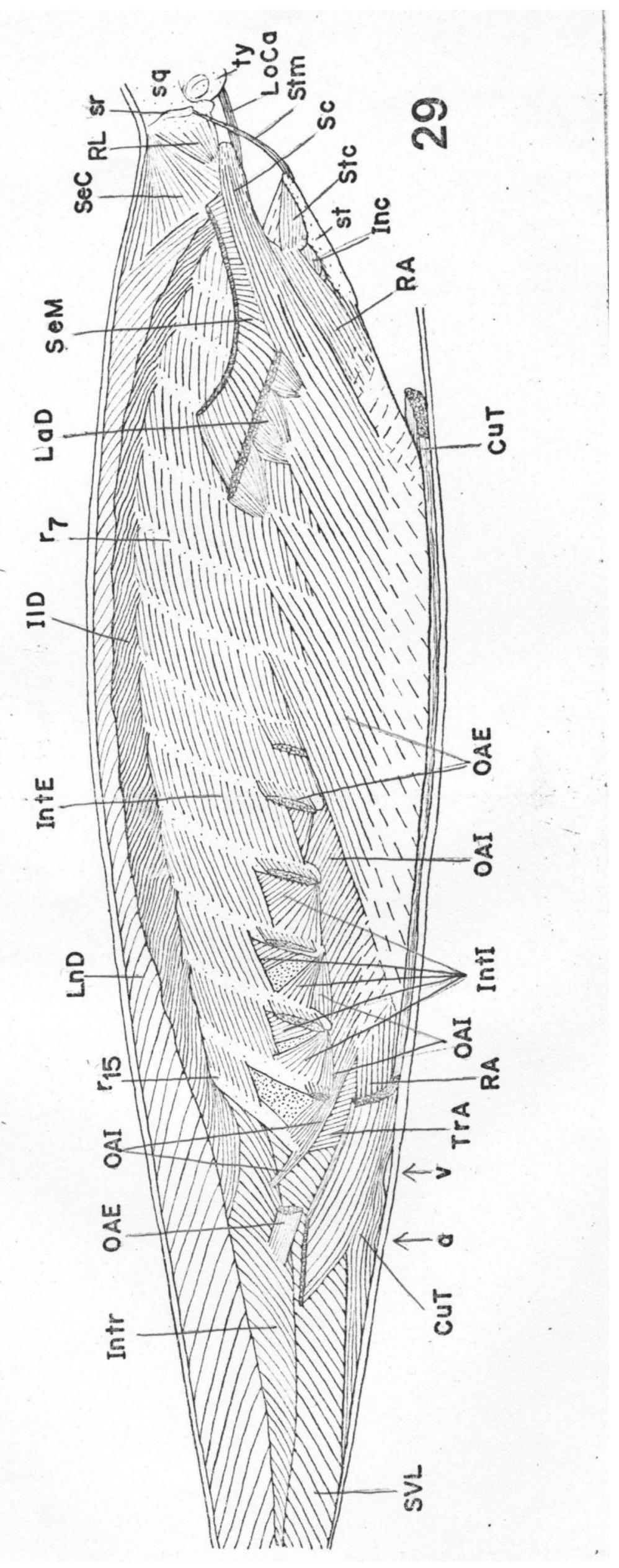



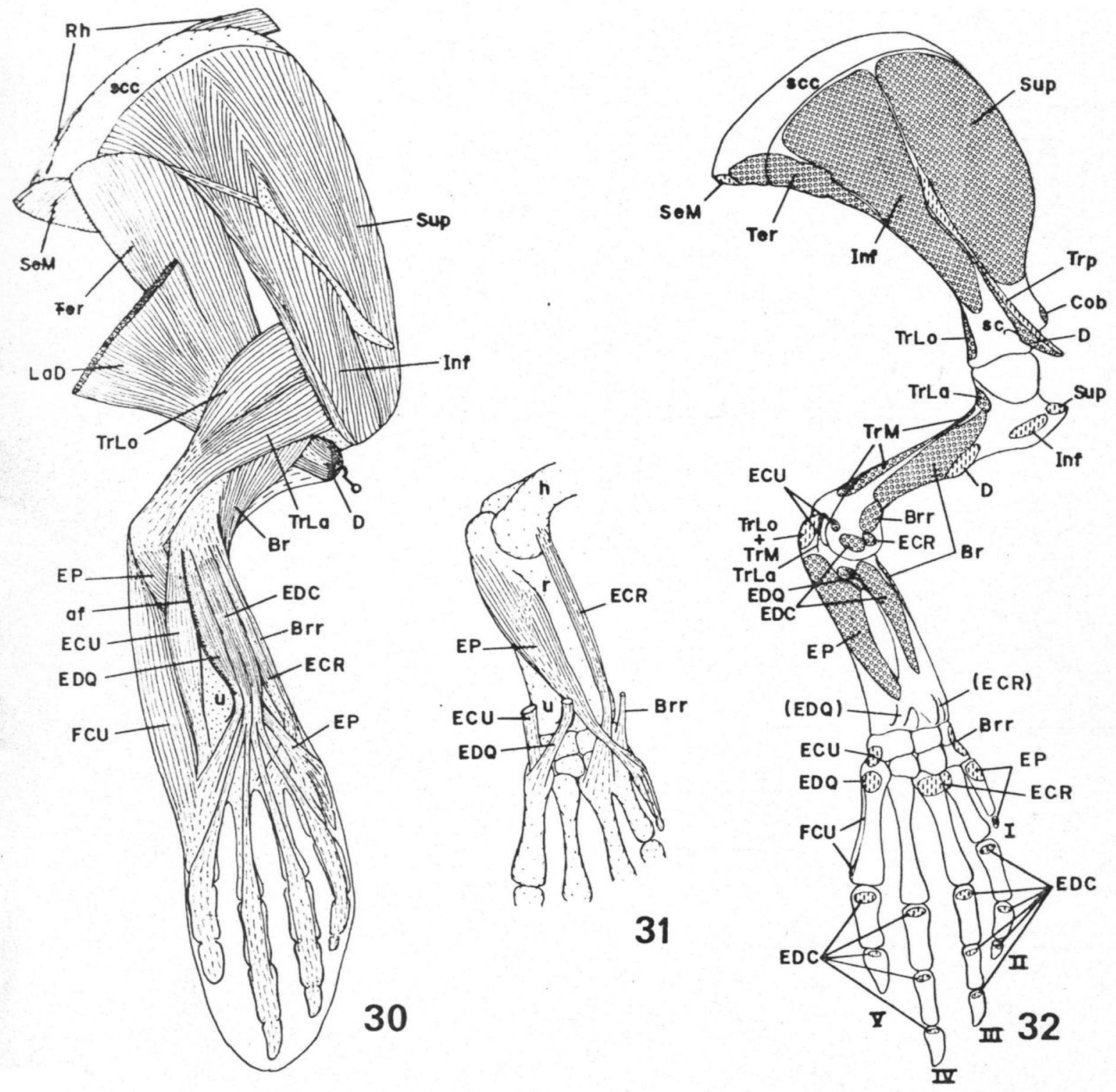


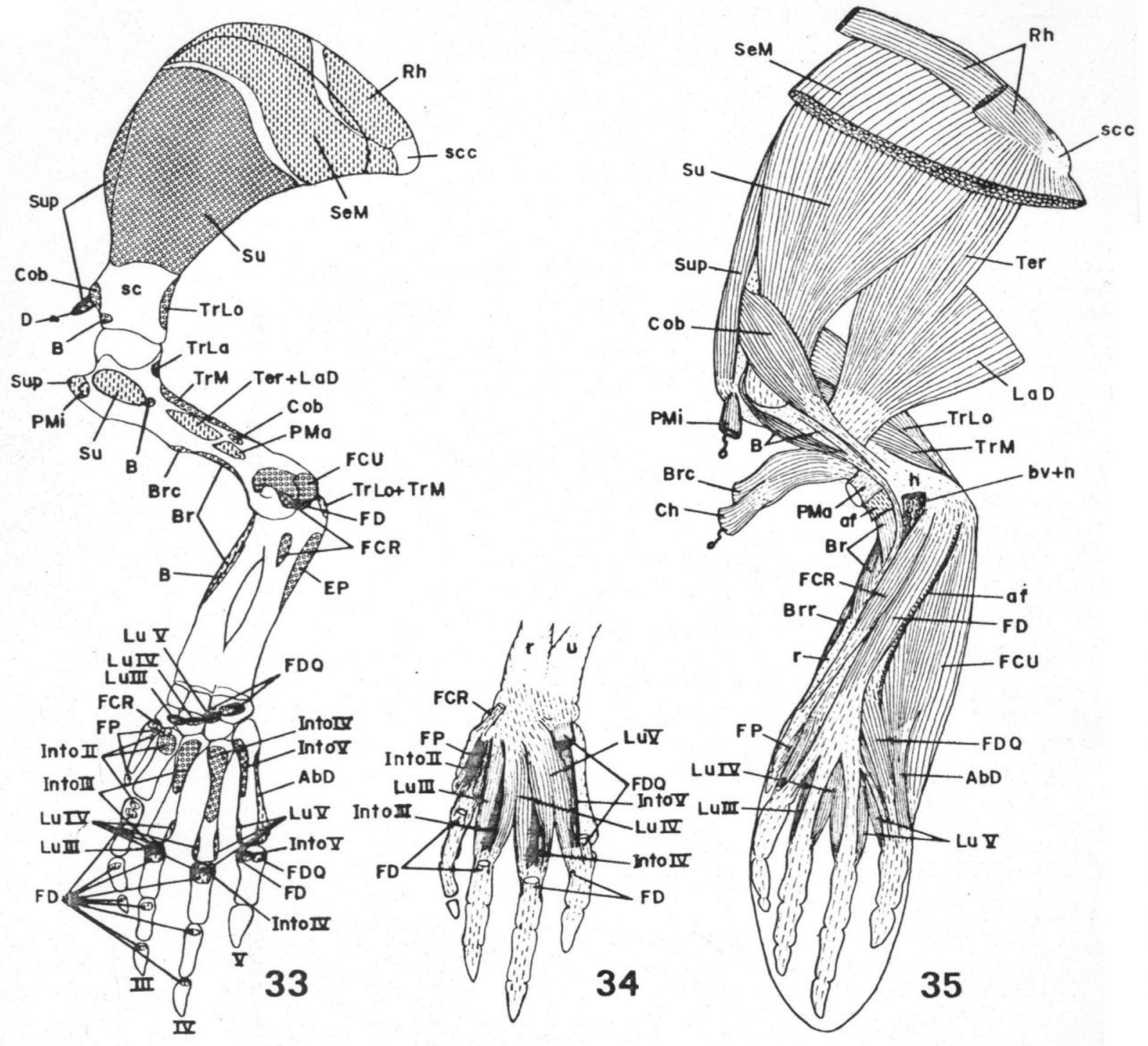



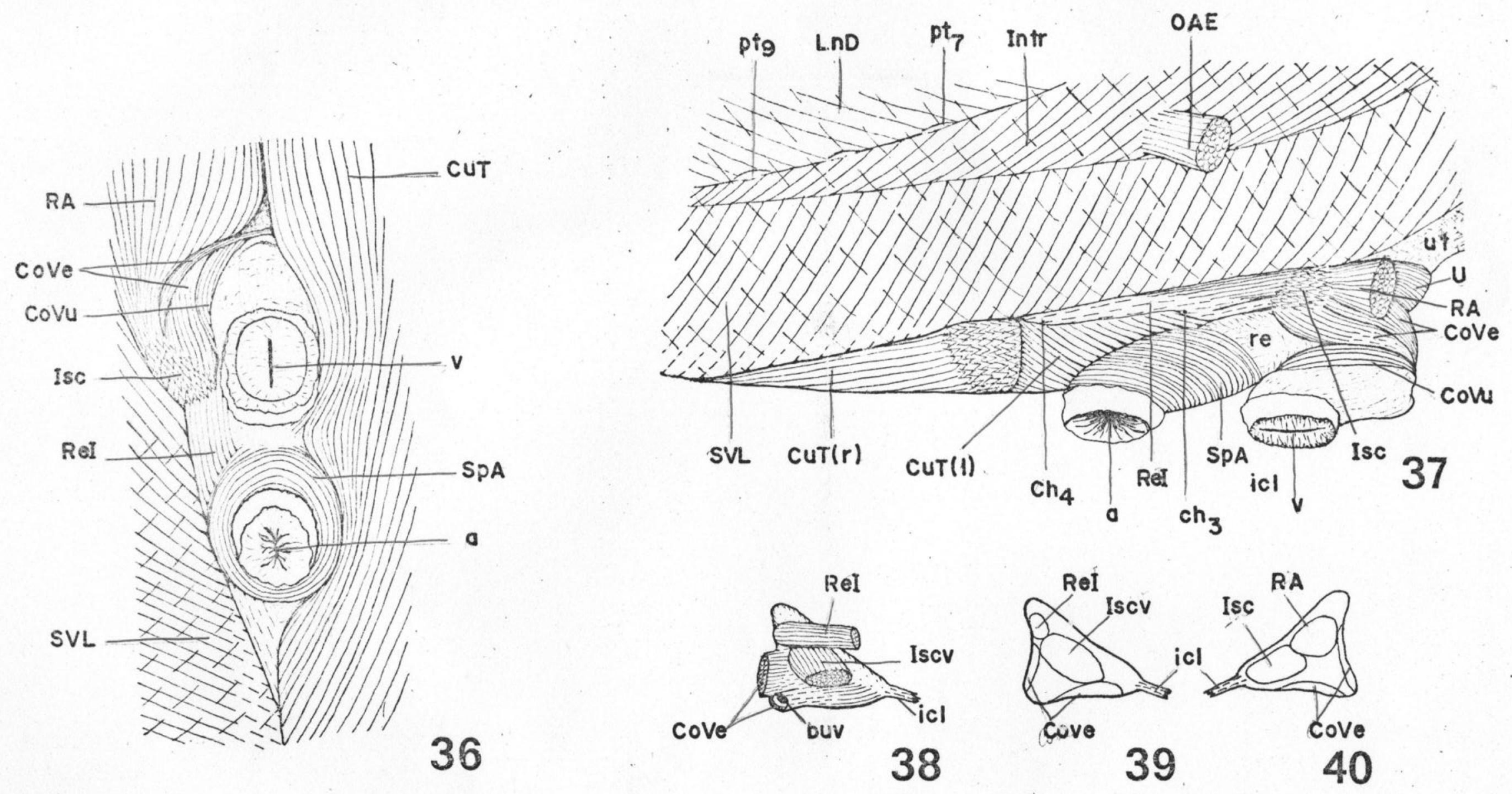


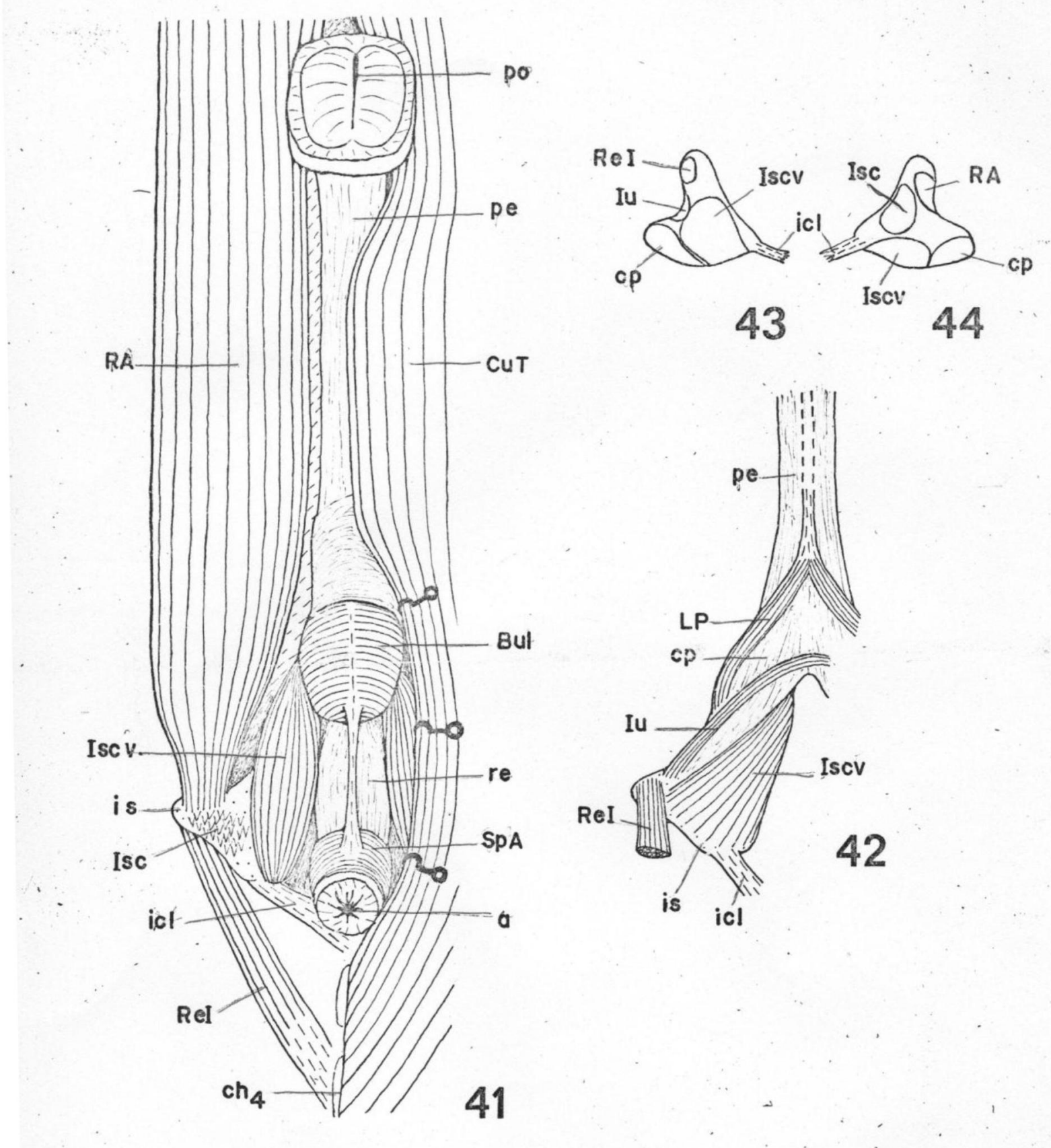



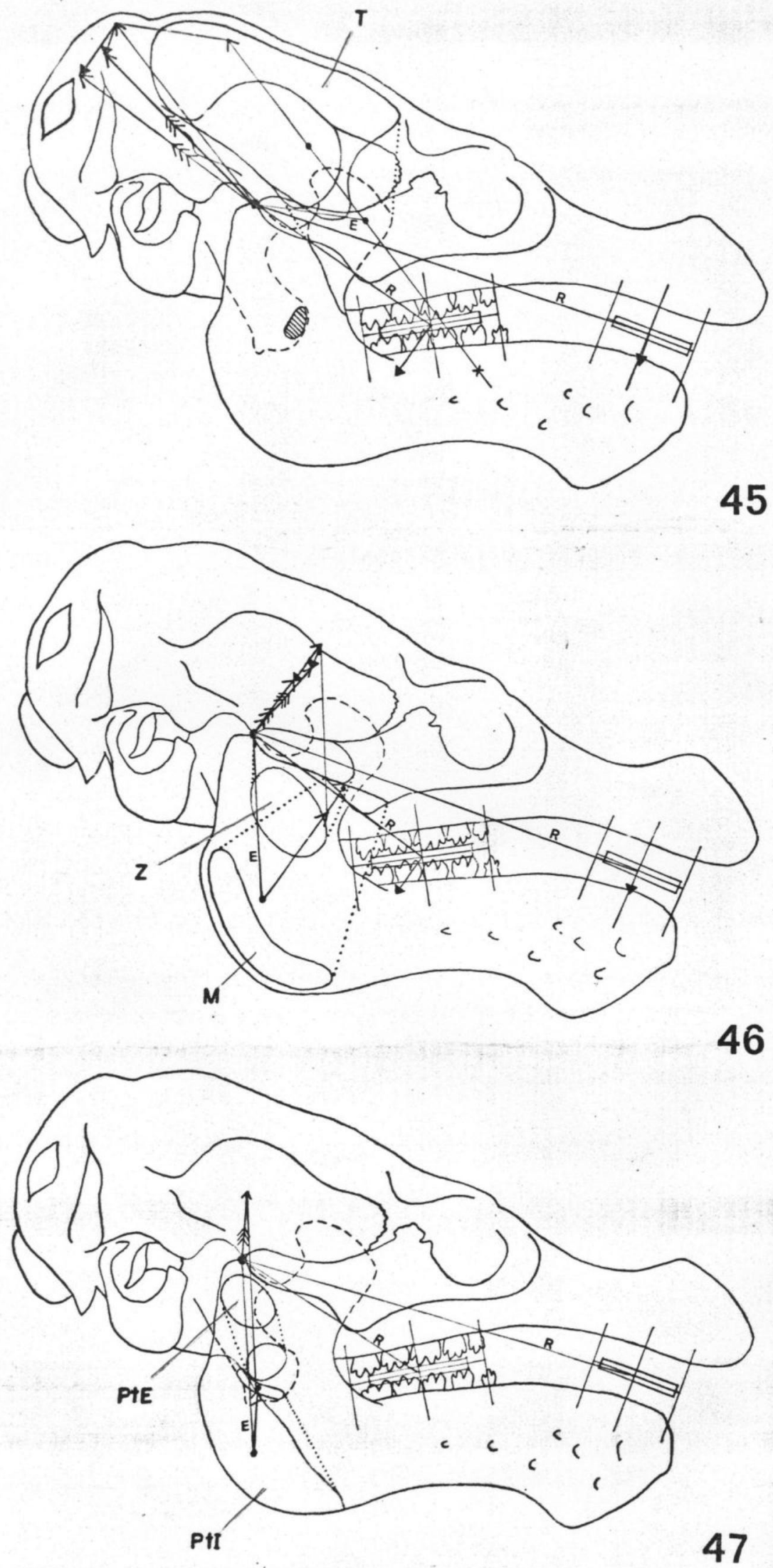


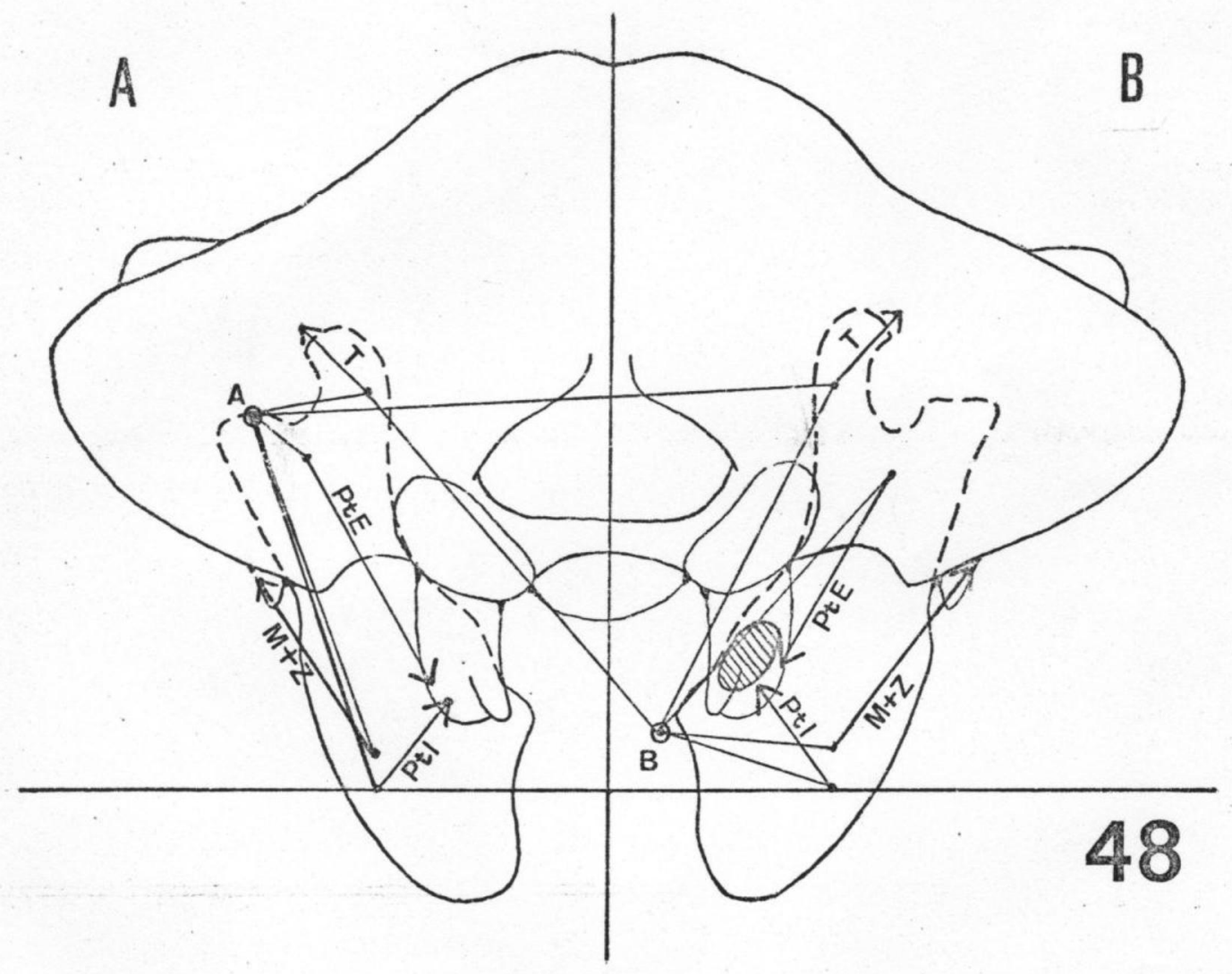




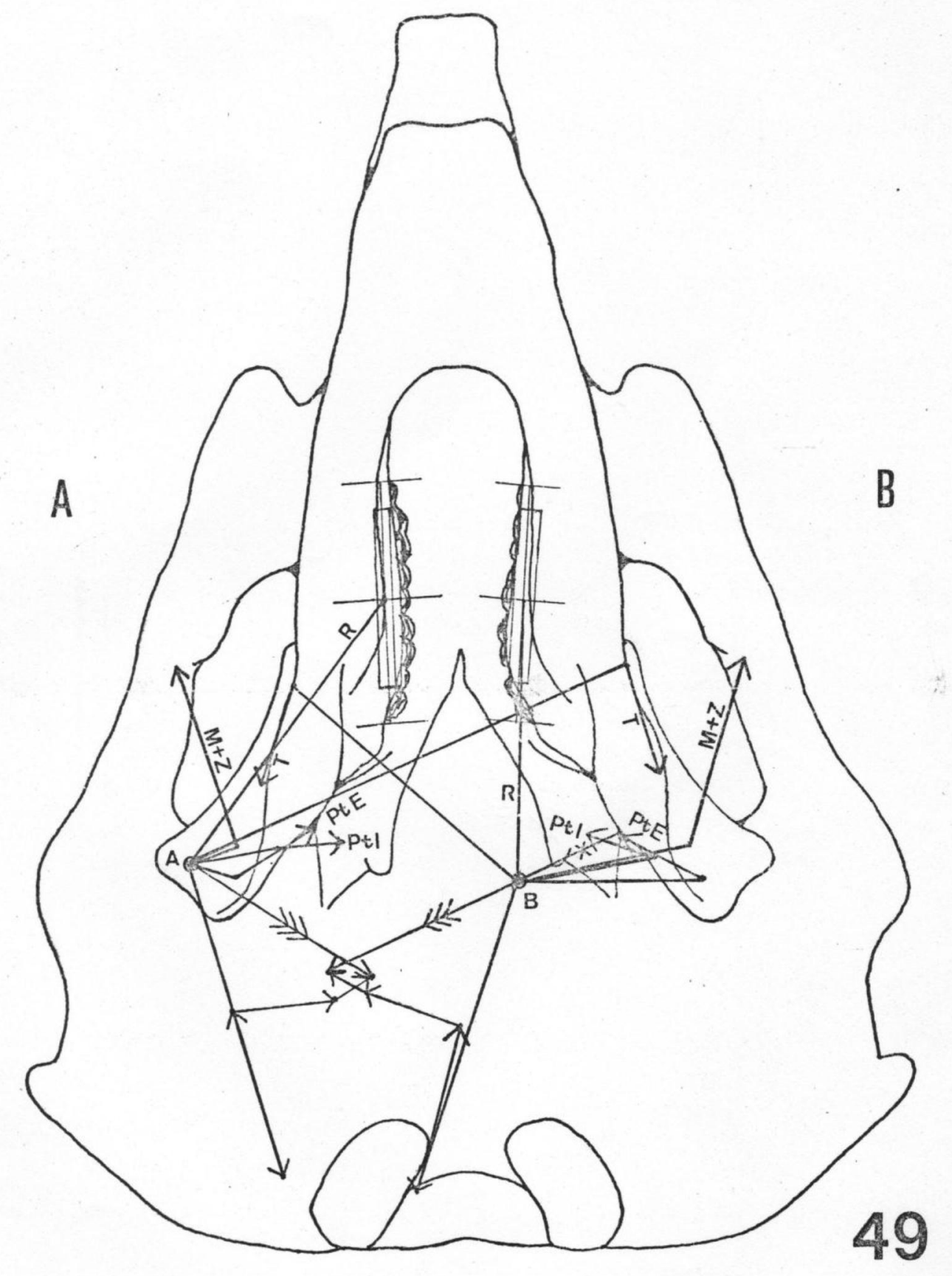




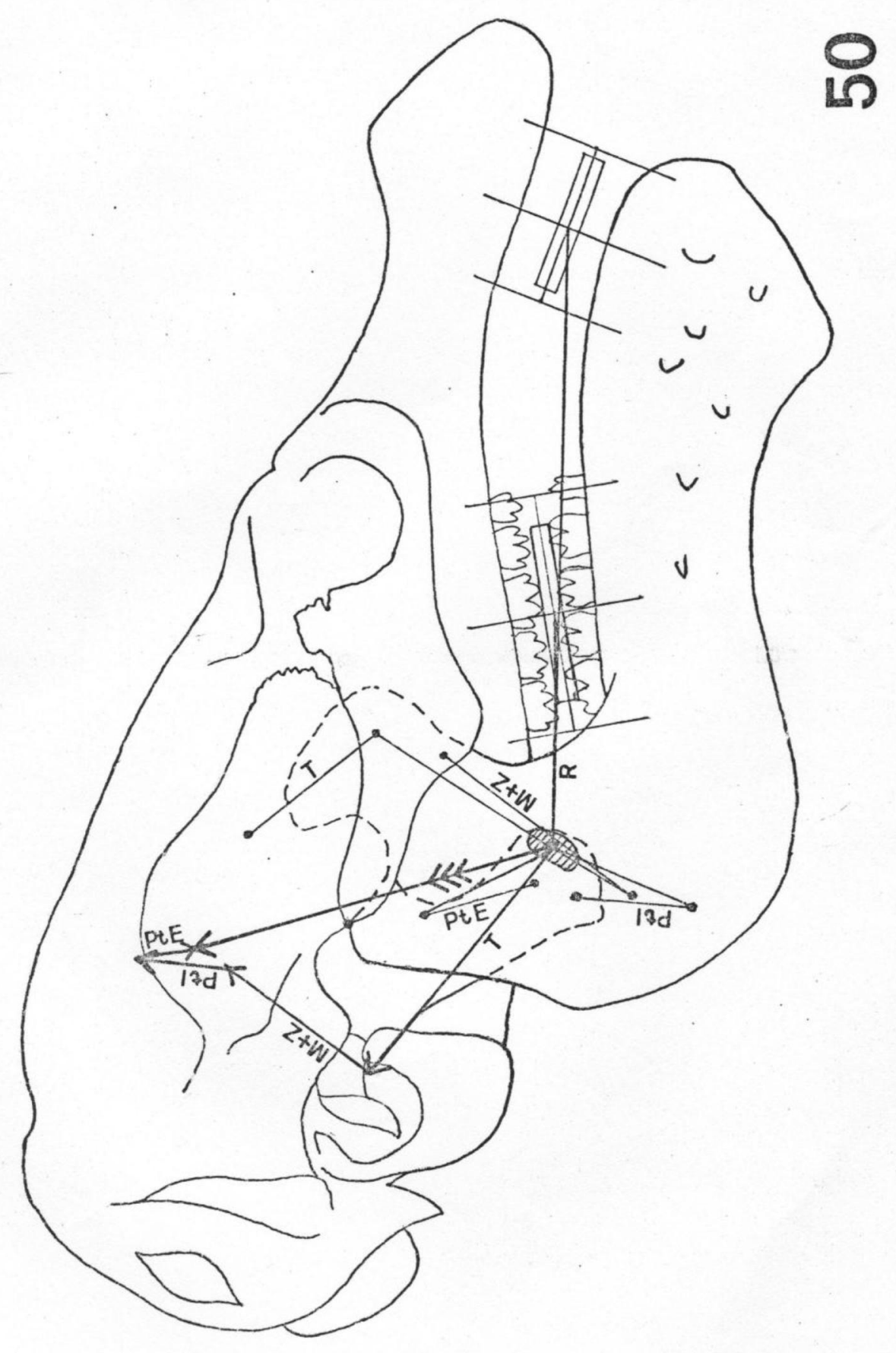

